Florida International University FIU Digital Commons

$11-8-2012$

\title{
Quorum Sensing and Microbial Interactions in Coral Black Band Disease and Coral-Associated Bacteria
}

Beth L. Zimmer

Florida International University, beth.zimmer@atkinsglobal.com

DOI: $10.25148 /$ etd.FI12120507

Follow this and additional works at: https://digitalcommons.fiu.edu/etd

\section{Recommended Citation}

Zimmer, Beth L., "Quorum Sensing and Microbial Interactions in Coral Black Band Disease and Coral-Associated Bacteria" (2012). FIU Electronic Theses and Dissertations. 781.

https://digitalcommons.fiu.edu/etd/781 


\title{
FLORIDA INTERNATIONAL UNIVERSITY
}

Miami, Florida

QUORUM SENSING AND MICROBIAL INTERACTIONS IN CORAL BLACK BAND DISEASE AND CORAL-ASSOCIATED BACTERIA

\author{
A thesis submitted in partial fulfillment of \\ the requirements for the degree of \\ MASTER OF SCIENCE \\ in \\ BIOLOGY \\ by
}

Beth L. Zimmer 
To: Dean Kenneth G. Furton

College of Arts and Sciences

This thesis, written by Beth L. Zimmer, and entitled Quorum Sensing and Microbial Interactions in Coral Black Band Disease and Coral-Associated Bacteria, having been approved in respect to style and intellectual content, is referred to you for judgment.

We have read this thesis and recommend that it be approved.

John Makemson

DeEtta Mills

Laurie Richardson, Major Professor

Date of Defense: November 8, 2012

The thesis of Beth L. Zimmer is approved.

Dean Kenneth G. Furton College of Arts and Sciences

Dean Lakshmi N. Reddi University Graduate School

Florida International University, 2012 


\section{ACKNOWLEDGMENTS}

I wish to express my gratitude for the large network of people that made completion of this degree possible. First and foremost, I wish to thank the members of my committee for their insight, support, and patience. The guidance and collaboration provided by my major professor, Dr. Laurie Richardson, was crucial in enabling my success and in overcoming the stumbling blocks that arose over the course of this degree. Thanks to Dr. John Makemson for his patient direction, instruction, and assistance with focusing this thesis project. I thank Dr. DeEtta Mills for lending crucial direction in molecular biology, as well as much needed encouragement.

Thanks to Dr. Lisa Schneper for the generous use and assistance with the luminometer. Special thanks to Zoe Pratte, Helen Garcia, and Sandra Perez for laboratory assistance. I am grateful for the support, guidance, and advice from the my colleagues at Florida International University, including Dr. Longin Kaczmarsky, Dr. Josh Voss, Dr. Raju Sekar, Dr. Miro Gantar, Dr. Aaron Miller, Zoe Pratt, Kristin Kuehl, Jamie Myers, Dina Stanić, and Abigael Brownell.

I wish to express my gratitude for financial assistance from my employer, Atkins North America, Inc., for this degree. Thanks to William F. Precht for providing the impetus to continue my education. Finally, I wish to thank my mother, Dr. Janet Zimmer, and my sister, Bree Zimmer, for their infinite encouragement and support. 
ABSTRACT OF THE THESIS

QUORUM SENSING AND MICROBIAL INTERACTIONS IN CORAL BLACK BAND DISEASE AND CORAL-ASSOCIATED BACTERIA

\author{
by \\ Beth L. Zimmer \\ Florida International University, 2012 \\ Miami, Florida \\ Professor Laurie Richardson, Major Professor
}

The black band disease (BBD) microbial consortium often causes mortality of reefbuilding corals. Microbial chemical interactions (i.e., quorum sensing (QS) and antimicrobial production) may be involved in the BBD disease process. Culture filtrates (CFs) from over 150 bacterial isolates from BBD and the surface mucopolysaccharide layer (SML) of healthy and diseased corals were screened for acyl homoserine lactone (AHL) and Autoinducer-2 (AI-2) QS signals using bacterial reporter strains. AHLs were detected in all BBD mat samples and nine CFs. More than half of the CFs ( $55 \%)$ tested positive for Al-2. Approximately $27 \%$ of growth challenges conducted among 19 isolates showed significant growth inhibition. These findings demonstrate that $\mathrm{QS}$ is actively occurring within the BBD microbial mat and that culturable bacteria from BBD and the coral SML are able to produce QS signals and antimicrobial compounds. This is the first study to identify AHL production in association with active coral disease. 


\section{TABLE OF CONTENTS}

CHAPTER

PAGE

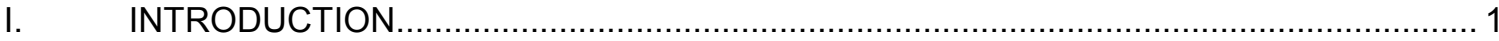

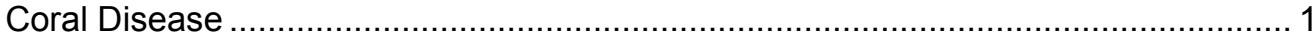

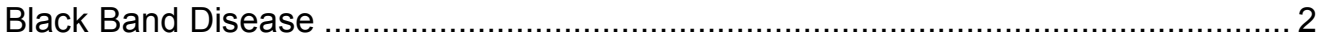

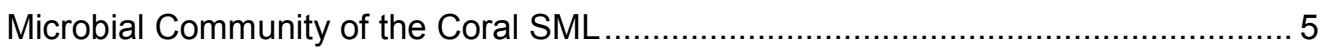

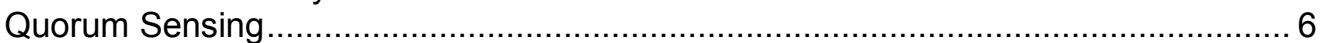

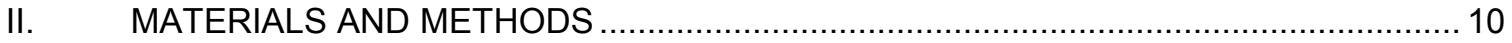

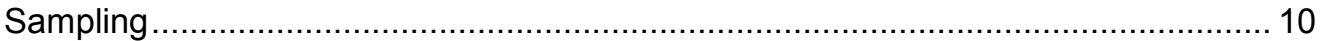

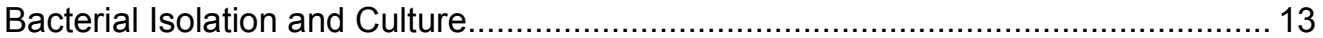

Acyl Homoserine Lactone Quorum Sensing Assays............................................. 16

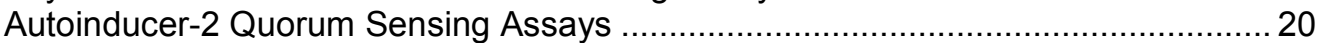

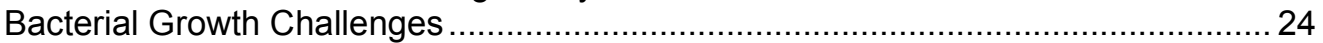

Sequencing of the 16S rRNA Gene of Bacterial Isolates .......................................... 26

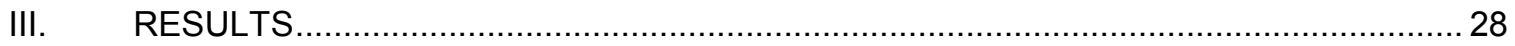

Acyl Homoserine Lactone Quorum Sensing Assays............................................. 28

Autoinducer-2 Quorum Sensing Assays .............................................................. 32

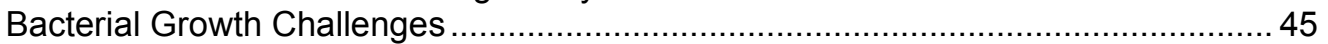

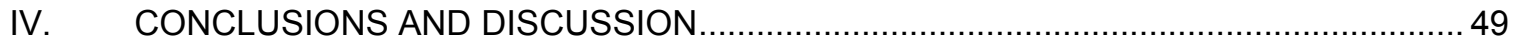

Quorum Sensing in Black Band Disease and Coral-Associated Bacteria ................. 49

Potential Fate of AHLs in the BBD Mat and Coral SML .......................................5 53

Potential Fate of Al-2 in the BBD Mat and Coral SML ......................................... 56

Allelopathy among Isolates from BBD and Coral SML ......................................... 57

Potential Roles of Signaling and Allelopathy in BBD and Coral SML ......................59

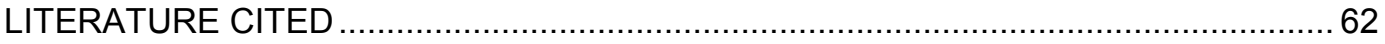

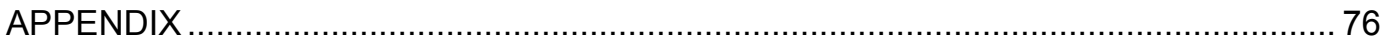




\section{LIST OF TABLES}

TABLE

PAGE

Table 1. Sampling information, including the geographic location of sampling sites, sampling date, depth, and water temperature for each sample collected. The number and species of coral colonies sampled at each site is presented, along with the sample type and naming scheme used for bacterial isolates from each sample. BBD: black band disease mat; BSML: surface mucopolysaccharide layer from BBD-infected coral colony; HSML: surface mucopolysaccharide layer from apparently healthy coral colony. 11

Table 2. Nine bacterial isolates obtained from black band disease on Siderastrea siderea colonies located on Horseshoe Reef, Lee Stocking Island, Bahamas. GenBank accession numbers and closest relative are provided. Sampling and 16S rRNA gene sequencing details were previously documented in Sekar et al. $(2006,2008)$ and Richardson et al. (2009)......

Table 3. Sampling location, coral host species, taxonomic information, and associated references for the cyanobacterial isolates examined in this study.

Table 4. Reporter strains used in the quorum sensing assays, the signals detected by each strain, and the corresponding reference.

Table 5. Experimental setup for the Al-2 assays showing the contents of each well type. The Medium Control wells were included to determine the optimal time point for the assay. The Blank well readings were used to correct the luminescence readings in the experimental wells. The Medium Reference wells were included to ensure that the MB and BG11 media were sterile. The $A B_{V h}$ Medium Reference wells were included to ensure that the $A B_{V h}$ medium was sterile and to correct the luminescence readings of the positive control.

Table 6. Experimental setup for the growth challenge assays showing the contents of each well type. The Culture Filtrate (CF) Reference well was monitored to ensure that the filtration step successfully removed all cells. The Blank wells were monitored to ensure the MB medium was sterile.

Table 7. The names of the 136 bacteria isolated for this study. Names are listed according to isolate type and individual colony. BBD: black band disease mat; BSML: surface mucopolysaccharide layer from BBD-infected coral colony; HSML: surface mucopolysaccharide layer from apparently healthy coral colony. Additional colony information is provided in Table 1.

Table 8. Bacterial isolates that tested positive for acyl homoserine lactone (AHL) production using the Chromobacterium violaceum CV026 and/or Agrobacterium tumefaciens NTL4(pZLR4) assays. CF: cell-free culture filtrate; BBD: black band disease; SML: surface mucopolysaccharide layer.

Table 9. Growth inhibition of the Chromobacterium violaceum CV026 and/or Vibrio harveyi BB170 reporter strains observed in the patch test and CF assays. Bolded isolates were positive for AHL production (Table 7).

Table 10. Identity of the nine isolates that produce AHL signals. The length of the $16 \mathrm{~S}$ rRNA gene sequence is presented, along with the information regarding the closest relative derived from a BLAST search, including the percent similarity and accession number. 
Table 11. Percentage of Al-2 activity ( \pm standard deviation) and induction of luminescence values for the $84 \mathrm{CFs}$ that tested positive in the Al-2 assay. The data are presented in descending order based on percentage of $\mathrm{Al}-2$ activity. The induction of luminescence was calculated by dividing the sample luminescence by the positive control luminescence at the optimal time point.

Table 12. Results of the AI-2 assay using the Vibrio harveyi BB170 reporter strain presented according to isolate type.

Table 13. Effect of exposure of the Vibrio harveyi BB170 reporter strain to culture filtrates of various isolates during the Al-2 assay. Effects included inhibition of growth and/or light production

Table 14. The number and percentage of isolate cultures that showed inhibition and stimulation of growth when challenged with the culture filtrates (CFs) of isolates from BBD, CFs of isolates from the SML of BBD-infected corals, and CFs of isolates from the SML of apparently healthy corals.

Table 15. The number and percentage of isolate cultures that showed inhibition and stimulation of growth when challenged with the culture filtrates (CFs) of isolates from AHL-producing isolates and non-QS isolates. 


\section{LIST OF FIGURES}

FIGURE

PAGE

Figure 1. Light production in the Vibrio harveyi BB170 Al-2 assay over time (from Taga 2005). In the absence of exogenous $\mathrm{Al}-2$ (control curve), light production initially decreases and then increases dramatically in response to autoinduction by the $V$. harveyi BB170 strain. When exogenous $\mathrm{Al}-2$ is available at the start of the assay (+Al-2 curve), light production is induced at a time point prior to autoinduction by $V$. harveyi BB170. Induction of luminescence is calculated at the optimal time point (see text), marked by the vertical line. .23

Figure 2. Positive results in colorimetric $A H L$ assay plates; $(A)$ Chromobacterium violaceum CV026 assay plate, showing a positive result (left) obtained from a BBD mat sample ; (B) Agrobacterium tumefaciens NTL4(pZLR4) assay plate showing a positive result (left) with the cell-free culture filtrate from BBD-FLK-1d. Positive control wells are located at the top of each plate.

Figure 3. A phylogenetic tree of the nine AHL-producing isolates, together with the best-matched sequences from the GenBank. Bootstrap probabilities are indicated at the branch nodes. The scale bar represents five substitutions per 100 nucleotide positions. GenBank accession numbers are provided in parentheses. Symbols: isolates tested positive for AHL production in the Agrobacterium tumefaciens NTL4(pZLR4) assay; isolates tested positive for AHL and Al-2 production in the A. tumefaciens NTL4(pZLR4) and Vibrio harveyi BB170 assay; $\Delta$ isolates tested positive for $\mathrm{AHL}$ and $\mathrm{Al}-2$ production in the Chromobacterium violaceum CV026, A. tumefaciens NTL4(pZLR4), and V. harveyi BB170 assays.

Figure 4. Representative experiment showing light production over time in the Al-2 assay. The curves generated by the cell-free culture filtrates (CFs) from BSML-FTL-7m and BSML-FTL$7 q$ (both positive in the Al-2 assay) follow the positive control curve. The curves generated by the CFs from BSML-FTL-7h and BSML-FTL-7k (both negative in the Al-2 assay) follow the Marine Broth (MB) medium control curve. Dashed vertical line indicates the optimal time point of the assay.

Figure 5. Light production of the media control wells and media reference wells in the Al-2 assay. The medium control curves indicate that the three growth media used in this study did not stimulate light production prior to self-induction by the Vibrio harveyi BB170 reporter strain. The luminescence of the medium reference wells, which contained sterile growth media, remained minimal over the course of the $\mathrm{Al}-2$ assay, although some minor increases in light were measured in these wells at the end of the assay due to light contamination from adjacent wells. Time of self-induction by the reporter strain is indicated by arrow. Table 5 shows contents of each well type in the Al-2 assay.

Figure 6. Light production versus optical density at $600 \mathrm{~nm}$ in the Al-2 assay. Presence of the CFs from six isolates inhibited both growth and luminescence of the Vibrio harveyi BB170 reporter strain; (a) BBD-FTL-5d; (b) HSML-FTL-10a, HSML-FTL-10c, HSML-FTL-10f, and HSML-FTL-10q; (c) HSML-FTL-11e.

Figure 7. Light production versus optical density at $600 \mathrm{~nm}$ in the Al-2 assay. Presence of the CF from BSML-FTL-7a inhibited growth of the Vibrio harveyi BB170 reporter strain but did not inhibit luminescence. 
Figure 8. Light production versus optical density at $600 \mathrm{~nm}$ in the Al-2 assay. Presence of the CF from BSML-FTL-7j inhibited luminescence without affecting growth of the Vibrio harveyi BB170 reporter strain. 


\section{INTRODUCTION}

\section{Coral Disease}

Coral reefs around the world have experienced substantial declines since the 1970 s (Gardner et al. 2003, Bellwood et al. 2004, Bruno and Selig 2007). As of 2008, it was estimated that coral reefs worldwide had effectively decreased by $19 \%$ of their original area (Wilkinson et al. 2008). Reefs have experienced severe declines within the Caribbean Basin (Weil 2004, AlvarezFilip et al. 2009), where coral cover has declined by $80 \%$ in the 25 years following 1977 (Gardner et al. 2003). It has recently been estimated that over $75 \%$ of coral reefs are rated as threatened, considering both direct threats from local anthropogenic impacts as well as thermal stress from increasing ocean temperatures (Burke et al. 2011). It is now widely believed that coral reef decline poses a major threat to the sustainability of coral reefs.

Coral diseases have been suggested to play a key role in the deterioration of reefs on a global basis (Hayes and Goreau 1998, Richardson 1998, Richardson et al. 1998, Rosenberg and Loya 2004, Sutherland et al. 2004, Harvell et al. 1999, 2007, 2009). Studies focused on Caribbean reefs have documented alarming trends related to increases in the number and incidence of coral diseases (Richardson 1998, Green and Bruckner 2000, Porter et al. 2001, Richardson et al. 2001, Sutherland et al. 2004, Weil 2004), as well as the number of coral species susceptible to disease (Richardson 1998, Porter et al. 2001). In the Caribbean, $82 \%$ of coral species are susceptible to disease, while only $25 \%$ of Indo-specific coral species are documented as susceptible (Sutherland et al. 2004).

Coral diseases have the capacity to alter coral reefs considerably by causing changes in the coral community structure (Done 1992, Knowlton 2001). Coral disease epizootics can lead to ecological phase shifts on a local or regional scale. For example, white band disease has nearly decimated the Acropora palmata and A. cervicornis populations in the Caribbean during recent decades (Aronson and Precht 2001a) by initiating a phase shift from the framework-building acroporid species to less ecologically important encrusting species (e.g., Agaricia spp. and Porites spp.). This phase shift was unprecedented in the fossil record (Aronson and Precht 
2001a,b). Additionally, Green et al. (2008) demonstrated that coral assemblages within the Caribbean have shifted, over approximately three decades (1974 to 2004), from massive, longlived species (e.g., Acropora and Montastraea) towards smaller species that grow rapidly and brood larvae (e.g., Porites and Agaricia). The shift is attributed, in part, to the impacts of coral disease on Caribbean reefs.

While the drivers behind the increases in numbers and incidence of coral diseases are still poorly understood, two probable explanations have been suggested: (1) decreased coral resistance to disease resulting from increased environmental stressors (e.g., thermal stress/bleaching and degraded water quality) and (2) increased virulence of pathogens from ocean warming (Sutherland et al. 2004, Bruno et al. 2007, Ellner et al. 2007, Harvell et al. 2007, 2009, Burke et al. 2011, Kaczmarsky et al. 2005).

\section{Black Band Disease}

Originally documented in 1973 on the reefs of the Florida Keys and Belize, black band disease (BBD) was the first coral disease to be reported within the scientific literature (Antonius 1976). Black band disease has been identified as one of the major coral diseases contributing to coral reef decline (Richardson and Aronson 2000, Rosenberg and Loya 2004, Weil et al. 2006). It infects both scleractinian and gorgonian corals worldwide (Sutherland et al. 2004) and infections frequently result in whole colony mortality (Richardson 1997, Sato et al. 2009). The prevalence of BBD is typically low, affecting $<1 \%$ of corals in a population (Garrett and Ducklow 1975, Edmunds 1991, Kuta and Richardson 1996, Voss and Richardson 2006); however, localized BBD outbreaks and epizootic events with much higher prevalence values have been documented on reefs of Florida (Richardson and Carlton 1993), Jamaica (Bruckner et al. 1997), and the central Great Barrier Reef (Sato et al. 2009). The fact that massive reef-building corals are susceptible to BBD (Antonius 1981, Rützler et al. 1983, Edmunds 1991, Sutherland et al. 2004, Kaczmarsky et al. 2005, Sekar et al. 2006, Voss and Richardson 2006) exacerbates the impact of the disease on reef ecology and function. Furthermore, while BBD infections have been documented to recur on recovered colonies (Borger 2005, Voss and Richardson 2006), it is 
less frequent that coral colonies are able to overgrow the exposed skeleton following a BBD infection (Bruckner and Bruckner 1997, Kuta and Richardson 1997, Richardson 2004). In addition, corals show low recruitment success rates on the newly available substrate created following BBD infection (Kuta and Richardson 1997, Richardson 1998, Edmunds 2000). Thus, BBD has the potential to contribute to the restructuring of reefs (Kuta and Richardson 1997).

Black band disease is easily distinguished in the reef environment and manifests as a black- or dark red-colored band (Viehman and Richardson 2000) separating healthy coral tissue from recently exposed coral skeleton (Rützler et al. 1983). The band may range from $1.0 \mathrm{~mm}$ to $7.0 \mathrm{~cm}$ in width (Carlton and Richardson 1995), though it is typically $0.5-1.0 \mathrm{~cm}$ wide (Richardson 2004). It is normally only up to $1.0 \mathrm{~mm}$ thick (Kuta and Richardson 1996, Richardson 2004). The band migrates horizontally across the surface of a coral colony, causing coral tissue necrosis at a rate of approximately $\sim 3.0 \mathrm{~mm}$ per day (Rützler et al. 1983); however, progression rates are variable and may exceed $1.0 \mathrm{~cm}$ per day (Rützler et al. 1983, Richardson 1996, Glas et al. 2012) or may cease completely during cooler periods (Rützler et al. 1983, Carlton and Richardson 1995, Kuta and Richardson 1996, Bruckner and Bruckner 1997, Voss and Richardson 2006). The tissue loss on an individual colony infected with BBD can be substantial and can result in total colony mortality (Edmunds 1991, Kuta and Richardson 1997, Sato et al. 2009).

The BBD mat consists of a microbial consortium that is similar in structure and function to microbial mats found in extreme environments, such as sulfidic thermal hot springs (Carlton and Richardson 1995). The members of the consortium are known to include at least one filamentous cyanobacterium (Antonius 1976, Ducklow and Mitchell 1979, Bythell et al. 2002, Cooney et al. 2002, Frias-Lopez et al. 2002, 2003, 2004, Sussman et al. 2006, Myers et al. 2007, Sato et al. 2009, 2010), sulfide-oxidizing bacteria presumed to be of the genus Beggiatoa (Garrett and Ducklow 1975, Ducklow and Mitchell 1979, Rützler et al. 1983, Viehman 2002, Sekar et al. 2008), sulfate-reducing bacteria including Desulfovibrio and Desulfobacter (Garrett and Ducklow 1975, Mitchell and Chet 1975, Cooney et al. 2002, Frias-Lopez et al. 2002, Viehman 2002, Sekar et al. 2006, Viehman et al. 2006, Barneah et al. 2007, Sato et al. 2010), numerous heterotrophic 
bacteria (Cooney et al. 2002, Frias-Lopez et al. 2002, 2004, Sekar et al. 2006, 2008, Barneah et al. 2007, Sato et al. 2010), and marine fungi (Ramos-Flores 1983). A meta-analysis of BBD clone libraries (Miller and Richardson 2011) detected a common cyanobacterial sequence, recently characterized as Roseofilum reptotaenium gen. et sp. nov. (Casamatta et al. 2012) present in $78 \%$ of 87 BBD samples from the Caribbean and Indo-Pacific.

The BBD microbial community is highly structured (Carlton and Richardson 1995), exhibiting both horizontal and vertical migration patterns (Carlton and Richardson 1995, Richardson 1996, Viehman and Richardson 2000). The entire BBD mat migrates horizontally as the band progresses along the coral colony, killing coral tissue (Richardson 1996). Within the horizontally migrating community, populations of both the dominant cyanobacteria and Beggiatoa migrate vertically within the band (Richardson 1996, Viehman and Richardson 2000). It has been shown experimentally that the BBD cyanobacteria migrate down into the band as light intensity increases (Viehman and Richardson 2000), while Beggiatoa migrates vertically to follow the movement of the oxygen/sulfide interface within the band (Richardson 1996). The structured microbial community creates microenvironments that vary in oxygen, $\mathrm{pH}$, and sulfide as a function of light intensity (Carlton and Richardson 1995, Glas et al. 2012). The combination of anoxic conditions and the presence of sulfide at the base of an active BBD mat was shown to be responsible for coral tissue necrosis (Richardson et al. 1997) and it has been shown that the presence of sulfide is required for initiation of BBD (Richardson et al. 2009). Establishment of the oxygen and sulfide microenvironments within the BBD mat is correlated with the rate of BBD migration across an infected coral (Glas et al. 2012).

While the literature has suggested a number of purported pathogens for BBD, a definitive pathogen (or pathogens) has yet to be established. The cyanobacterium Oscillatoria submembranaceae (Antonius 1981), reclassified based on morphology as Phormidium corallyticum (Rützler et al. 1983), and more recently formally characterized as Roseofilum reptotaenium (Casamatta et al. 2012) was one of the first suggested BBD pathogens. The idea of a cyanobacterial primary pathogen is supported by the meta-analysis conducted by Miller and 
Richardson (2011), which detected a common cyanobacterial operational taxonomic unit (OTU) corresponding to Roseofilum reptotaenium in the majority of global BBD samples. Other suggested BBD pathogens include Beggiatoa spp. (Garrett and Ducklow 1975), Desulfovibrio spp. (Mitchell and Chet 1975), and various heterotrophs (Cooney et al. 2002, Frias-Lopez et al. 2002, 2004). Several authors have proposed that BBD is not caused by a singular primary pathogen, but is rather a polymicrobial disease with a pathogenic microbial consortium (Carlton and Richardson 1995, Richardson and Kuta 2003, Richardson 2004, Barneah et al. 2007). In this scenario, the presence of certain microbes predisposes the coral host to colonization by additional microbes by creating specific biogeochemical microenvironments, and together these non-pathogenic microbes result in disease (Barneah et al. 2007, Glas et al. 2012). It has also been suggested that bacterial and cyanobacterial toxins (Sekar et al. 2006, Richardson et al. 2007, Myers et al. 2007, Gantar et al. 2009, Stanić et al. 2011) and proteolytic activity by Vibrio species (Arotsker et al. 2009) may also play a role in the pathology of BBD. Currently, there is not a conclusive understanding of BBD pathology and pathogenicity.

\section{Microbial Community of the Coral SML}

The coral surface mucopolysaccharide layer (SML) supports a dynamic microbial community (Brown and Bythell 2005, Guppy and Bythell 2006, Kooperman et al. 2007) which is believed to play important roles in biogeochemical cycling and disease resistance in the host coral (Mouchka et al. 2010). The interaction between coral pathogens and the microbial community of the coral SML has been the subject of multiple studies (reviewed in Mouchka et al. 2010). The Coral Probiotic Hypothesis, developed by Reshef et al. (2006), proposes that corals live in a symbiotic relationship with their associated microbial community and that when environmental conditions change, the coral's microbial population may also change to adapt to the novel environmental conditions. It is suggested that coral pathogens are likely present in healthy corals at low concentrations, and that environmental stressors (e.g., elevated temperature, elevated nutrient levels, lowered $\mathrm{pH}$ ) may trigger a shift in the coral's resident microbial community from a community associated with healthy corals to one associated with 
disease (Ducklow and Mitchell 1979, Vega Thurber et al. 2009, Bourne et al. 2008, 2009, Meron et al. 2011). The coral SML and its associated microbes have been shown to produce antimicrobial agents (Ritchie 2006, Nissimov et al. 2009, Shnit-Orland and Kushmaro 2009, Rypien et al. 2010) that may be acting to protect corals from pathogen growth. The SML of apparently healthy Acropora palmata colonies was shown to contain substances that inhibit biofilm formation by the white pox pathogen, Serratia marcescens (Alagely et al. 2011).

Relatively little is currently known about the interactions between microbes within the

SML. Furthermore, interactions between members of the BBD consortium and bacteria inhabiting the host coral's SML may be a key component of the disease process. If secondary metabolite production by the members of the BBD consortium influences the growth of the SML-associated bacteria (i.e., alters the host coral SML microbial community), then host coral resistance/susceptibility could be impacted. Chemical signaling and antimicrobial production are two modes of microbial interaction that may be occurring in these systems.

\section{Quorum Sensing}

Quorum sensing (QS) refers to the phenomenon of density dependent cell-cell communication among bacteria (Fuqua et al. 1994). Bacteria capable of QS release signaling molecules called autoinducers (Als) into the external environment (Nealson 1977, Bassler 1999, de Kievit and Iglewski 2000, Watters and Bassler 2005). When only a small number of bacteria are present, the Al concentration is insufficient for detection or response by neighboring bacteria; however, with a higher density of bacteria, the Al concentration reaches a threshold that allows the bacteria to respond to a critical cell mass. The bacteria then coordinate their behavior by regulating gene expression, thereby controlling the bacterial phenotype (high vs. low cell density) and initiating a population-wide response (de Kievit and Iglewski 2000, Watters and Bassler 2005, Jayaraman and Wood 2008). A variety of QS systems have been detected in both Gramnegative and Gram-positive bacteria (Gera and Srivastava 2006, Jayaraman and Wood 2008). Quorum sensing is utilized for communication within and between bacterial species, as well as between kingdoms (i.e., prokaryotes and eukaryotes; Bandara et al. 2012). 
The QS signals are a chemically diverse group of molecules. Most QS signals (Als) are either small organic molecules or peptides containing 5-20 amino acids (Williams 2007). The very first QS signal to be described is Autoinducer-1 (Al-1), or $\beta$-ketocaproyl homoserine lactone (Eberhard et al. 1981). Autoinducer-1 is a member of one of the best-characterized groups of QS molecules, the acyl homoserine lactones (AHLs). The basic structure of the AHL molecule consists of a core homoserine lactone ring attached to fatty acid (acyl) side chain between 4-18 carbons in length (Fuqua et al. 2001, Chhabra et al. 2005). Acyl homoserine lactone production has been well documented among members of the Gram-negative proteobacteria (Williams 2007, Jayaraman and Wood 2008). More than 70 species of bacteria have been demonstrated to produce one or more AHL signals (Williams 2007). The AHLs are unique on the basis of their length, saturation, and/or substitutions on the acyl side chain (Fuqua et al. 2001, Chhabra et al. 2005). The AHL signals are recognized by members of the same species, as AHL receptors typically display preferential binding to the AHL produced by that bacterium (Bassler 2002, Waters and Bassler 2005, Steindler and Venturi 2007, Bandara et al. 2012). While AHLs are considered intraspecies signals, signal-mediated cross-talk between bacteria does occur. There are a number of bacterial species that can recognize the same AHL (e.g., Wood et al. 1997, Welch et al. 2000, Riedel et al. 2001, Ryan and Dow 2008). Furthermore, some bacteria can respond to an $\mathrm{AHL}$ signal that is produced by a variety of different bacteria (Greenberg et al.1979, Bassler et al. 1997, Pierson et al. 1998).

Another well-characterized QS signal group is the Autoinducer-2 (AI-2) signal, which includes a group of furanones comprised of different, interconverting chemical moieties that are all derived from the same precursor molecule as AHLs, S-adenosylmethionine (Schauder et al. 2001, Chen et al. 2002). Signaling with Al-2 has been detected in both Gram-negative and Grampositive bacteria (DeKeersmaecker et al. 2006, Gonzalez and Keshavan 2006) and is widely recognized for its role in interspecies communication (Bassler 1999, 2002, McDougald et al. 2003, Xavier and Bassler 2003, Rickard et al. 2006, Novick and Geisinger 2008, Bandara et al. 2012). To date, the luxS gene that encodes the Al-2 synthase has been identified in over 55 
species of Gram-negative and Gram-positive bacteria (De Keersmaecker et al. 2006) and Al-2 is referred to as the "universal signaling molecule" (Miller and Bassler 2001, Jayaraman and Wood 2008). In addition to the bacteria that are producing the Al-2 signal, many bacteria that do not possess the luxS gene can still detect and respond to Al-2 in the environment (Sun et al. 2004).

Quorum sensing is associated with a range of interactive social responses in bacteria, including virulence, antibiotic synthesis, biofilm maintenance and maturation, motility, symbiosis, aggregation, swarming, plasmid conjugal transfer, exoenzyme production, and bioluminescence (Bassler 1999, Joint et al. 2007a). Quorum sensing has been shown to regulate virulence in both Gram-positive pathogens (e.g., Staphylococcus aureus) and Gram-negative pathogens (e.g., Vibrio cholerae, Pseudomonas aeruginosa, Burkholderia pseudomallei, and B. cenocepacia) (Bandara et al. 2012). For some bacterial pathogens, QS molecules are involved in the establishment of an infection and may be used to regulate a bacterial strain's switch from a nonpathogenic to a pathogenic state (de Kievit and Iglewski 2000, Jayaraman and Wood 2008). These QS-regulated systems may be used to avoid alerting the host's immune response to a pathogen's presence until sufficient bacterial numbers have amassed to achieve a successful infection (Bassler 1999, de Kievit and Iglewski 2000, Wu et al. 2005). In addition, QS systems have been linked to antibiotic biosynthesis in Erwinia carotovora (McGowan et al. 2005) and Pseudomonas aureofaciens (Wood et al. 1997). Furthermore, biofilm development in certain bacteria (e.g., Escherichia coli, V. cholera, P. aeruginosa, B. cepacia, Serratia liquefaciens) is reliant upon QS systems (Davies et al. 1998, Huber et al. 2001, Labbate et al. 2004, Barrios et al 2006, Waters et al. 2008).

Recent studies have detected QS signal production in isolates from the coral holobiont and in coral pathogens. Alagely et al. (2011) detected AHL production in bacteria isolated from marine invertebrates and their endosymbiotic dinoflagellates, including coral-associated microbes. Similarly, Golberg et al. (2011) demonstrated AHL production in coral-associated bacteria isolated from the SML of healthy corals. Vibrio spp. isolated from healthy and diseased corals have been shown to produce QS signals, specifically AHLs and AI-2 (Tait et al. 2010). The 
coral pathogen Serratia marcescens is known to utilize AHL QS systems to regulate virulence factors, including biofilm formation, swarming, swimming motility, biosurfactant production, exoenzyme and antibiotic production, and nucleases (Van Houdt et al. 2007). In situ production of QS signals in coral disease has not yet been demonstrated and the role of these signals in the coral microbial community and in coral disease remains unknown.

Despite nearly 40 years of research, the etiology, pathogenesis, and pathogenicity of BBD remain unresolved. The mechanisms of BBD mat formation and organization, the mode of microbial recruitment to the BBD community, and the factors leading to initiation of lesions are not yet fully understood. The role of QS systems in virulence, antibiotic production, and biofilm structure makes QS an important aspect of study for BBD. Furthermore, potential roles of the coral microbial community in BBD infection and host susceptibility remain unresolved. Quorum sensing and chemical interactions between BBD microbial constituents and/or the coral microbial community may be contributing to the disease process. The goal of this study was to screen members of the BBD microbial consortium and the coral SML microbial community for QS signal production and antimicrobial activity. 


\section{MATERIALS AND METHODS}

My study examined the culture filtrates from 153 bacterial strains that were isolated from the BBD microbial mat, from the SML of BBD-infected coral colonies, and from the SML of apparently healthy coral colonies. For the remainder of this document, these isolates will be referred to as "BBD isolates," "isolates from BBD-infected corals," and "isolates from healthy corals," respectively.

\section{Sampling}

Of the 153 strains examined in this study, 136 were isolated from environmental samples that were collected using the following protocol. Samples of the BBD microbial mat and host coral SML were collected from colonies of Montastraea cavernosa and Diploria strigosa located on the Florida reef tract. Samples were collected from the reef near Commercial Blvd. in Ft. Lauderdale, Broward County, Florida, USA and from Algae Reef, Florida Keys, USA (Table 1). Sterile, needleless $10 \mathrm{ml}$ syringes were used to collect the BBD disease mat, as well as SML from the BBD-infected coral colony located at the farthest distance (i.e., a minimum of 20 $\mathrm{cm}$ ) from the BBD mat. In addition, SML was collected from apparently healthy coral colonies located in close proximity to the BBD-infected coral. To collect the BBD mat, the mat material was drawn into the syringe. To collect the SML, the coral surface was first lightly agitated using the syringe tip (to cause mucus secretion) and the resulting mucus was suctioned with the syringe. Immediately upon return to the shore, the syringes were inverted, allowing the mucus or mat material to settle to the tip of the syringe. The samples were held in the dark at ambient temperature until return to the laboratory.

Nine of the bacterial isolates examined in this study were already in culture in the laboratory of Dr. Laurie Richardson at Florida International University. These strains were isolated and the 16S rRNA gene sequences were previously attained (Sekar et al. 2006, 2008; Richardson et al. 2009). Table 2 provides a summary of the sampling information and taxonomic identification for these nine isolates. 
Table 1. Sampling information, including the geographic location of sampling sites, sampling date, depth, and water temperature for each sample collected. The number and species of coral colonies sampled at each site is presented, along with the sample type and naming scheme used for bacterial isolates from each sample. BBD: black band disease mat; BSML: surface mucopolysaccharide layer from BBDinfected coral colony; HSML: surface mucopolysaccharide layer from apparently healthy coral colony.

\begin{tabular}{|c|c|c|c|c|c|c|c|c|}
\hline $\begin{array}{c}\text { Site Name and } \\
\text { Location }\end{array}$ & $\begin{array}{l}\text { Sample Site } \\
\text { Coordinates }\end{array}$ & Date of Collection & $\begin{array}{c}\text { Water } \\
\text { Depth (m) }\end{array}$ & $\begin{array}{c}\text { Water } \\
\text { Temp }\left({ }^{\circ} \mathrm{C}\right) \\
\end{array}$ & $\begin{array}{c}\text { Colony } \\
\text { No. }\end{array}$ & Coral Species & $\begin{array}{c}\text { Sample } \\
\text { Types }\end{array}$ & $\begin{array}{c}\text { Isolate Naming } \\
\text { Scheme }\end{array}$ \\
\hline \multirow{11}{*}{$\begin{array}{c}\text { Ft. Lauderdale, } \\
\text { Broward County, } \\
\text { FL, USA }\end{array}$} & \multirow{11}{*}{$\begin{array}{c}26^{\circ} 11.35^{\prime} \mathrm{N}, \\
80^{\circ} 5.49^{\prime} \mathrm{W}\end{array}$} & 17-May-08 & 3.7 & 28 & FTL 1 & Montastraea cavernosa & BBD & BBD-FTL-1x* \\
\hline & & 27-Jun-08 & 4.6 & 28 & FTL 2 & Montastraea cavernosa & BBD & BBD-FTL-2x \\
\hline & & 27-Jun-08 & 4.3 & 28 & FTL 3 & Montastraea cavernosa & BBD & BBD-FTL-3x \\
\hline & & 27-Jun-08 & 4.0 & 28 & FTL 4 & Montastraea cavernosa & BBD & BBD-FTL-4x \\
\hline & & 27-Jun-08 & 3.3 & 28 & FTL 5 & Montastraea cavernosa & BBD & BBD-FTL-5x \\
\hline & & 1-Aug-09 & 4.6 & 29 & FTL 6 & Montastraea cavernosa & BBD, BSML & \begin{tabular}{|l} 
BBD-FTL-6x \\
BSML-FTL-6x \\
\end{tabular} \\
\hline & & 31-Jul-10 & 3.7 & 30 & FTL 7 & Montastraea cavernosa & BBD, BSML & \begin{tabular}{|l|} 
BBD-FTL-7x \\
BSML-FTL-7x \\
\end{tabular} \\
\hline & & 31-Jul-10 & 4.3 & 30 & FTL 8 & Montastraea cavernosa & BBD, BSML & \begin{tabular}{|l} 
BBD-FTL-8x \\
BSML-FTL-8x \\
\end{tabular} \\
\hline & & 31-Jul-10 & 4.6 & 30 & FTL 9 & Diploria strigosa & HSML & HSML- FTL-9x \\
\hline & & 31-Jul-10 & 4.3 & 30 & FTL 10 & Montastraea cavernosa & HSML & HSML- FTL-10x \\
\hline & & 31-Jul-10 & 4.3 & 30 & FTL 11 & Montastraea cavernosa & HSML & HSML- FTL-11x \\
\hline $\begin{array}{c}\text { Algae Reef, } \\
\text { Florida Keys, FL, } \\
\text { USA }\end{array}$ & $\begin{array}{l}25^{\circ} 08.799^{\prime} \mathrm{N}, \\
80^{\circ} 17.579^{\prime} \mathrm{W}\end{array}$ & 24-Oct-09 & 6.7 & 25 & FLK 1 & Diploria strigosa & BBD, BSML & $\begin{array}{l}\text { BBD-FLK-1x } \\
\text { BSML-FLK-1x }\end{array}$ \\
\hline \multirow{2}{*}{$\begin{array}{l}\text { Horseshoe Reef, } \\
\text { Lee Stocking } \\
\text { Island. Bahamas }\end{array}$} & \multirow{2}{*}{$\begin{array}{l}23^{\circ} 46.30^{\prime} \mathrm{N} \\
76^{\circ} 5.33^{\prime} \mathrm{W}\end{array}$} & 19-Jul-04 & 8.2 & 29 & 216 & Siderastrea siderea & BBD & BBD-216-x \\
\hline & & 19-Jul-04 & 7.3 & 28 & 217 & Siderastrea siderea & BBD & BBD-217-x \\
\hline
\end{tabular}

*The " $x$ " in the naming scheme references the individual isolate names (e.g., BBD-FTL-1a, BBD-FTL-1b, etc.). 
Table 2. Nine bacterial isolates obtained from black band disease on Siderastrea siderea colonies located on Horseshoe Reef, Lee Stocking Island, Bahamas. GenBank accession numbers and closest relative are provided. Sampling and 16S rRNA gene sequencing details were previously documented in Sekar et al. $(2006,2008)$ and Richardson et al. (2009).

\begin{tabular}{|l|l|l|l|}
\hline Isolate Name & $\begin{array}{c}\text { GenBank } \\
\text { Accession No. }\end{array}$ & \multicolumn{1}{|c|}{ Closest Relative (\% Similarity) } & \multicolumn{1}{|c|}{$\begin{array}{c}\text { GenBank Accession } \\
\text { No. of Closest Relative }\end{array}$} \\
\hline BBD-216-1b & GQ901063 & Vibrio harveyi strain NCIMB1280 (99\%) & NR043165 \\
\hline BBD-216-2d & GQ901065 & Vibrio harveyi strain NCIMB1280 (99\%) & NR043165 \\
\hline BBD-216-3d & GQ901066 & Bacillus megaterium strain IAM 13418 (99\%) & NR043401 \\
\hline BBD-216-4a & GQ901054 & Loktanella hongkongensis strain UST950701-009P (96\%) & NR029121 \\
\hline BBD-216-4e & GQ901057 & Bacillus aquimaris strain TF-12 (99\%) & NR025241 \\
\hline BBD-217-2b & GQ901070 & Kocuria palustris strain TAGA27 (99\%) & NR026451 \\
\hline BBD-217-2d & GQ901071 & Vibrio harveyi strain NCIMB1280 (99\%) & NR043165 \\
\hline BBD-217-2g & GQ901072 & Alteromonas macleodii strain 107 (99\%) & NR037127 \\
\hline BBD-217-3m & GQ901076 & Bacillus safensis strain FO-036b (99\%) & \\
\hline
\end{tabular}


The present study also examined cultures of eight cyanobacterial strains that had been previously isolated from samples of BBD collected in the Florida Keys, Bahamas, and Philippines. These strains were already in culture in the laboratories of Dr. Laurie Richardson and Dr. Miroslav Gantar at Florida International University. Table 3 provides a summary of the sampling information and taxonomic identification for these cyanobacterial strains.

\section{Bacterial Isolation and Culture}

In the laboratory, the SML samples were extruded carefully into sterile $2 \mathrm{ml}$ tubes in order to limit the amount of seawater in the sample. The BBD mat, which forms a clump once removed from the coral colony, was removed from the syringe using sterile forceps and placed in autoclaved seawater. The BBD sample was then vortexed and a standard dilution series was prepared using both the SML and BBD mat samples. The diluted samples were spread onto plates containing the following media: Difco marine agar (MA, Difco 2216), 1/10 strength Difco MA, and Thiosulfate Citrate Bile Salts Sucrose (TCBS; Vibrio-specific, BD) agar. The plates were incubated at room temperature $\left(\sim 23^{\circ} \mathrm{C}\right)$ and unique colonies were selected on the basis of color and morphology, for further isolation and evaluation.

The isolates were assigned names corresponding to their associated sample origin (see Table 1). Isolates named "BBD" were obtained from a BBD mat sample, isolated named "BSML" were obtained from the SML of a BBD-infected colony, and isolates named "HSML" were obtained from the SML of an apparently healthy colony. The "FTL" and "FLK" portion of the name corresponds to the sample collection location (Ft. Lauderdale and Florida Keys, respectively). The nine BBD cultures previously isolated (Table 2) were maintained on Difco marine agar, as described above. Laboratory cultures of the eight cyanobacterial strains (Table 3) were maintained in $125 \mathrm{ml}$ Erlenmeyer flasks containing the mineral media ASNIII and marine BG11, which support photoautotrophic growth of cyanobacteria. These media were prepared as described by Rippka et al. (1979), although artificial seawater was used to prepare the BG11 medium to support the marine cultures. The cultures were maintained at $26^{\circ} \mathrm{C}$ under a $12: 12 \mathrm{hr}$ light:dark fluorescent light regime with an intensity of $20 \mu \mathrm{E} \mathrm{m} \mathrm{s}^{-2}$. 
Table 3. Sampling location, coral host species, taxonomic information, and associated references for the cyanobacterial isolates examined in this study.

\begin{tabular}{|c|c|c|c|c|c|}
\hline Isolate Name & $\begin{array}{l}\text { Sample } \\
\text { Location }\end{array}$ & Coral Species & $\begin{array}{c}\text { Closest Relative } \\
(\% \text { Similarity })\end{array}$ & $\begin{array}{c}\text { GenBank } \\
\text { Accession } \\
\text { No. } \\
\end{array}$ & References \\
\hline BBD 1991 & Florida Keys & Montastraea annularis & Geitlerinema (99\%) & DQ151461 & $\begin{array}{l}\text { Ragoonath (2005) } \\
\text { Richardson and Kuta (2003) }\end{array}$ \\
\hline HS 217 & Bahamas & Siderastrea siderea & Geitlerinema (99\%) & EF110974 & $\begin{array}{l}\text { Myers et al. (2007) } \\
\text { Voss and Richardson (2006) }\end{array}$ \\
\hline HS 223 & Bahamas & Siderastrea siderea & Geitlerinema (99\%) & DQ680351 & $\begin{array}{l}\text { Myers et al. (2007) } \\
\text { Voss and Richardson (2006) }\end{array}$ \\
\hline$W-1$ & Florida Keys & Siderastrea siderea & Geitlerinema (99\%) & EF154084 & Myers et al. (2007) \\
\hline FLK BBD1 & Florida Keys & Montastraea annularis & Leptolyngbya (98\%) & EF110975 & $\begin{array}{l}\text { Myers et al. (2007) } \\
\text { Richardson et al. (2007) } \\
\text { Voss and Richardson (2006) }\end{array}$ \\
\hline Phil 2b-2 & Philippines & Porites lutea & Leptolyngbya (98\%) & EF372581 & Myers et al. (2007) \\
\hline $102 a-1$ & Florida Keys & Dendrogyra cylindrus & Leptolyngbya (97\%) & EU743966 & Gantar et al. (2009) \\
\hline $96-2$ & Florida Keys & Montastraea annularis & Leptolyngbya (N/A) ${ }^{a}$, b & N/A & Gantar et al. (2011) \\
\hline
\end{tabular}

${ }^{\text {a }}$ Not sequenced.

${ }^{b}$ Identified using classic taxonomic criteria based on morphology. 


\section{Preparation of Cell-Free Culture Filtrates}

Cell-free culture filtrates (CFs) from the bacterial isolates were collected for use in the QS assays and the bacterial growth challenges. To obtain the CFs, the test isolates were grown in sterile Difco marine broth (MB, Difco 2216) that was filtered twice (Whatman 1 paper filters, 5.5 $\mathrm{cm}$ ) to remove the medium precipitate. The cultures were grown to stationary phase at $29^{\circ} \mathrm{C}$ with shaking. This temperature is ecologically relevant, since surface water temperatures range from $28-30^{\circ} \mathrm{C}$ during the summer on the reefs of Broward County (Vargas-Angel et al. 2003), which is the season when BBD tends to be most active (Rützler et al. 1983, Edmunds 1991, Kuta and Richardson 1996, Bruckner and Bruckner 1997, Jones et al. 2004, Borger 2005, Voss and Richardson 2006). The bacterial cell concentrations were monitored by measuring the optical density at $600 \mathrm{~nm}\left(\mathrm{OD}_{600}\right)$ using either a Modulus ${ }^{\mathrm{TM}}$ Microplate Multimode Reader (Turner BioSystems, Sunnyvale, CA, USA) or a Thermo UV1 Spectrophotometer (Thermo Electron Ltd., Cambridge, UK). Sterile marine broth was used as a zero/blank.

At early stationary phase, CF samples were prepared by centrifugation at $12,000 \mathrm{~g}$ for 10 minutes. The $\mathrm{pH}$ of the resulting supernatant was assessed using a Jenco Model 60 Digital pH meter (Jenco Electronics, Ltd., Taipei, Taiwan) and the supernatant was divided into two, $1 \mathrm{ml}$ aliquots. Alkaline conditions have been shown to result in AHL lactonolysis, which is hydrolysis of the lactone ring (Voelkert and Grant 1970, Yates et al. 2002, Byers et al. 2002). Because AHLs have been shown to remain stable for extended time periods (months) at pH 5.0-6.0 (Schaefer et al. 2000), the $\mathrm{pH}$ of the supernatant to be used in the $\mathrm{AHL}$ assays was adjusted to an acidic condition ( $\mathrm{pH}$ 5.0-6.0) using a sterile $\mathrm{HCl}$ solution (1N). Each $\mathrm{CF}$ was then filter sterilized by passing the supernatant through a $0.22 \mu \mathrm{m}$ membrane filter (Millipore, Billerica, MA, USA) placed at the tip end of a sterile syringe. The CFs were collected in a sterile cryovial and stored at $-20^{\circ} \mathrm{C}$ until ready for use in appropriate assay.

For the cyanobacterial strains, CFs were prepared by obtaining a $2 \mathrm{ml}$ aliquot from an active cyanobacterial culture. The culture sample was vortexed and cells were removed using a combination of centrifugation (12,000 $\mathrm{g}$ for 10 minutes) and filter sterilization by passing the 
supernatant through a $0.22 \mu \mathrm{m}$ membrane filter (Millipore, Billerica, MA, USA) placed at the tip end of a sterile syringe. The CFs were collected in a sterile tube and used immediately in the quorum sensing assays.

\section{Acyl Homoserine Lactone Quorum Sensing Assays}

The bacterial strains isolated from the coral SML and the BBD microbial consortium, the BBD mat itself, and the previously isolated cyanobacterial strains, were evaluated for the production of $\mathrm{AHL}$ and $\mathrm{Al}-2$ signal molecules.

Acyl Homoserine Lactone (AHL) Reporter Strains

The Chromobacterium violaceum CV026 reporter strain was used to detect the presence of short-chain AHLs in the bacterial CFs. The Agrobacterium tumefaciens NTL4(pZLR4) reporter strain and the A. tumefaciens NTL4(pTiC58 $\triangle a c c R)$ mutant strain were used to test the bacterial CFs for the presence of AHLs with medium-to-long chains in the bacterial CFs. Table 4 summarizes the signals recognized by each reporter strain. The $C$. violaceum strain was obtained from Dr. Kalai Mathee (Florida International University) and the A. tumefaciens strains were obtained from Dr. Stephen K. Farrand (University of Illinois).

Table 4. Reporter strains used in the quorum sensing assays, the signals detected by each strain, and the corresponding reference.

\begin{tabular}{|l|l|l|}
\hline Reporter Strain & Signal Detection & Reference \\
\hline \multirow{5}{*}{ Chromobacterium violaceum CV026 } & C4-AHL & \\
& C6-3-oxo-AHL & McClean et al. (1997) \\
C8-AHL & Steindler and Venturi (2007) \\
& C8-3-oxo-AHL & \\
\hline \multirow{5}{*}{ Agrobacterium tumefaciens NTL4(pZLR4) } & C6-AHL & \\
& C8-AHL & \\
& C10-AHL & \\
& C12-AHL & Cha et al. (1998) \\
& C6-3-hydroxy-AHL & Steindler and Venturi (2007) \\
& C8-3-hydroxy-AHL & \\
& C10-3-hydroxy-AHL & \\
& All 3-oxo-AHLs & \\
\hline
\end{tabular}


Wild type Chromobacterium violaceum produces violacein, a purple, water-insoluble pigment whose production is regulated by AHLs. Chromobacterium violaceum CV026 is a miniTn5 (violacein-negative) mutant strain unable to produce the AHLs required for violacein production. When C. violaceum CV026 is exposed to exogenous AHLs, violacein production is induced (McClean et al. 1997). The C. violaceum CV026 strain acts as a biosensor for AHLs that have short carbon chains (C4-C8; Table 4).

Similarly, wild type Agrobacterium tumefaciens produces an AHL signal while the reporter strain used in this study does not. The A. tumefaciens NTL4(pZLR4) mutant lacks a the tral gene which codes for the $\mathrm{AHL}$ synthase and also contains a reporter gene (lacZ) that is fused to the quorum sensing-regulated gene (traG). In the presence of exogenous AHLs, the lacZ fusion is activated and $\beta$-galactosidase is expressed. A blue color is produced by the $\beta$-galactosidase cleavage of 5-bromo-4-chloro-3-indolyl-beta-D-galactopyranoside (X-gal; Shaw et al. 1997). The A. tumefaciens NTL4(pZLR4) reporter strain acts as a biosensor for AHLs with medium-to-long carbon chains (C6-C14; Table 4). In these experiments a second mutant strain was used as a

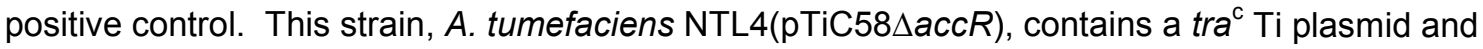
constitutively synthesizes the AHL quormone signal, AAl (Beck von Bodman et al. 1992).

\section{Chromobacterium violaceum CV026 Assay}

The Chromobacterium violaceum CV026 assay used in this study follows the protocol of McClean et al. (1997) with slight modification. The C. violaceum CV026 reporter strain was cultured in sterile Difco Luria-Bertani (LB) broth overnight at $30^{\circ} \mathrm{C}$ and used to prepare the assay plates. The assay plates contained a base of $1.5 \%$ Difco LB agar with an overlay consisting of $100 \mu \mathrm{l}$ of the $C$. violaceum CV026 culture $\left(\mathrm{OD}_{600}=1.0\right)$ in $5 \mathrm{ml}$ of $0.7 \%$ Difco LB agar. These assay plates were used to evaluate the following for the presence of short-chain AHLs: 1) the bacterial CFs, 2) the BBD mat material, and 3) patch tests of the bacterial isolates.

To test the bacterial CFs, wells were punched in triplicate assay plates using the wide end of a sterile pipette tip. To each experimental well, $75 \mu \mathrm{l}$ of the appropriate CF was added. To test the BBD mat material, a portion of each BBD samples was placed $1.0 \mathrm{ml}$ of sterile 
seawater. The mixture was shaken on a vortexer and $75 \mu \mathrm{l}$ of the solution was placed into an experimental well in the assay plate. Each triplicate test plate contained a positive control of 0.01 $\mu \mathrm{l}$ of $50 \mathrm{mM} \mathrm{N}$-hexanoyl-L-homoserine lactone, which was spotted on the agar surface, and a negative control well with either $75 \mu \mathrm{l}$ of sterile marine broth for the CF assays or $75 \mu \mathrm{l}$ of sterile seawater for the BBD mat assays. The test plates were incubated for 24 hours at $30^{\circ} \mathrm{C}$ and then examined for the stimulation of violacein production, as indicated by the presence of purple (violacein) coloration surrounding the wells.

For the bacterial isolate patch tests, each isolate was streaked onto a plate containing Difco MA and incubated at $29^{\circ} \mathrm{C}$ until colonies were visible. Colonies were collected using a sterile loop and transferred to the surface of the C. violaceum CV026 assay plates. In the case of the cyanobacterial strains, clumps of cyanobacteria were selected from the culture flask using sterile forceps and transferred to the surface of the assay plate. Each experiment was conducted with triplicate test plates, each plate containing a positive control with $0.01 \mu \mathrm{l}$ of $50 \mathrm{mM} \mathrm{N}$ hexanoyl-L-homoserine lactone, which was spotted on the agar surface. The assay plates were incubated for 24 hours at $30^{\circ} \mathrm{C}$ and then assessed for violacein presence.

Agrobacterium tumefaciens NTL4(pZLR4) Assay

The Agrobacterium tumefaciens NTL4(pZLR4) assay used in this study follows the protocol of Farrand et al. (2002) with slight modification. The A. tumefaciens NTL4(pZLR4) frozen glycerol stock was streaked on a plate containing autoinducer bioassay minimal $\left(A B_{A t}\right)$ agar (i.e., $3 \mathrm{~g} / \mathrm{L} \mathrm{K}_{2} \mathrm{HPO}_{4}, 1 \mathrm{~g} / \mathrm{L} \mathrm{NaH} \mathrm{HPO}_{4}, 1 \mathrm{~g} / \mathrm{L} \mathrm{NH}_{4} \mathrm{Cl}, 0.3 \mathrm{~g} / \mathrm{L} \mathrm{MgSO} \mathrm{MS}_{4} \cdot 7 \mathrm{H}_{2} \mathrm{O}, 0.15 \mathrm{~g} / \mathrm{L} \mathrm{KCl}, 0.01$ $\mathrm{g} / \mathrm{LCaCl}_{2}, 0.0025 \mathrm{~g} / \mathrm{L} \mathrm{FeSO}{ }_{4} \cdot 7 \mathrm{H}_{2} \mathrm{O}$; Chilton et al. 1974), along with $5 \mathrm{~g} / \mathrm{L}$ mannitol $(0.5 \%)$ and gentamicin $(30 \mu \mathrm{g} / \mathrm{ml})$ and incubated at $28^{\circ} \mathrm{C}$ until colonies were visible.

A single colony was transferred via sterile loop to $1 \mathrm{ml}$ of $A B_{A t}$ medium with gentamicin $(30 \mu \mathrm{g} / \mathrm{ml})$ and grown overnight at $28^{\circ} \mathrm{C}$ with shaking. The day of the assay, a fresh solution of $A B_{A t}$ medium with gentamicin $(3 \mu \mathrm{g} / \mathrm{ml})$ was prepared, inoculated with $50 \mu \mathrm{l}$ of the overnight culture, and grown late exponential phase at $28^{\circ} \mathrm{C}$ with shaking. The assay plates contained a base of $1.5 \% \mathrm{AB}_{\mathrm{At}}$ agar $(0.5 \%$ mannitol) with an overlay that included $500 \mu \mathrm{l}$ of the $A$. 
tumefaciens NTL4(pZLR4) culture in $5 \mathrm{ml}$ of $0.7 \%$ water agar with gentamycin $(30 \mu \mathrm{g} / \mathrm{ml})$ and Xgal $(40 \mu \mathrm{g} / \mathrm{ml})$. These assay plates were used to evaluate the following for the presence of medium-to-long chain AHLs: 1) the bacterial CFs, 2) the BBD mat material, and 3) patch tests of the bacterial isolates.

To test the bacterial CFs, wells were punched in the triplicate assay plates using the wide end of a sterile pipette tip. To each experimental well, $75 \mu$ of the test sample CF, or $75 \mu$ of BBD mat/sterile seawater solution (prepared as described above), was added to the experimental wells. The positive control for this assay consisted of $0.5 \mu \mathrm{l}$ of cell-free culture filtrate from Agrobacterium tumefaciens NTL4(pTiC58 $\triangle a c c R)$, which was spotted on the agar surface. To prepare the positive control solution, $A$. tumefaciens NTL4(pTiC58 $\Delta a c c R)$ was grown to saturation in $\mathrm{AB}_{\mathrm{At}}$ broth at $28^{\circ} \mathrm{C}$ with shaking, an aliquot of the culture was centrifuged at $12,000 \mathrm{~g}$ for 10 minutes, and the resulting supernatant was filter sterilized using a $0.22 \mu \mathrm{m}$ membrane filter (Millipore, Billerica, MA, USA) placed at the tip end of a sterile syringe. The negative control well on each plate contained either $75 \mu$ of sterile marine broth for the CF assays or $75 \mu$ l of sterile seawater for the BBD mat assays. The assay plates were incubated for 24 hours at $28^{\circ} \mathrm{C}$ and then assessed for the presence of X-gal cleavage, as indicated by blue coloration surrounding the wells.

For the bacterial isolate patch tests, each isolate was streaked onto a plate containing Difco marine agar and incubated at $29^{\circ} \mathrm{C}$ until growth was visible. Colonies were collected using a sterile loop and transferred to the surface of the A. tumefaciens NTL4(pZLR4) assay plates. In the case of the cyanobacterial strains, clumps of cyanobacteria were selected from the culture flask using sterile forceps and transferred to the surface of the assay plate. Each test was conducted in triplicate and each test plate contained a positive control consisting of $0.5 \mu$ l of cellfree culture filtrate from A. tumefaciens NTL4(pTiC58 $\mathrm{acc} R)$, which was spotted on the agar surface. The assay plates were incubated for 24 hours at $28^{\circ} \mathrm{C}$ and then assessed for blue coloration. 
Patch tests that result in blue coloration on the A. tumefaciens NTL4(pZLR4) assay plates can indicate the following: 1) the bacterial isolate synthesized AHLs recognized by the $A$. tumefaciens NTL4(pZLR4) reporter strain, or 2) the bacterial isolates produced an extracellular factor that hydrolyzed the X-gal in the assay plate. Thus, those bacterial isolate patch tests that resulted in a potential positive result (blue coloration) were tested for $\beta$-galactosidase activity. The patch tests were repeated on a plate containing only $\mathrm{AB}_{\mathrm{At}}$ agar $(0.5 \%$ mannitol) with $\mathrm{X}$-gal $(40 \mu \mathrm{g} / \mathrm{L})$. The assay plates were incubated for 24 hours at $28^{\circ} \mathrm{C}$ and then assessed for blue coloration. Isolates exhibiting $\beta$-galactosidase activity were considered to be a false positive result for the A. tumefaciens NTL4(pZLR4) patch test assay.

\section{Autoinducer-2 Quorum Sensing Assays}

Two mutant strains of Vibrio harveyi were used in the Al-2 assays for this study: $V$. harveyi BB170 (Al-2 reporter strain) and V. harveyi BB152 (Al-2 positive control strain). The wildtype V. harveyi contains three parallel QS systems, producing: (1) CAI-1, a Vibrio-specific QS signal identified as (S)-3-hydroxytridecan-4-one (Higgins et al. 2007), (2) an AHL (i.e., N-(3hydroxybutanoyl)-L-homoserine lactone or HAI-1; Bassler et al. 1997), and (3) the AI-2 signal, a furanosyl borate diester (Bassler et al. 1994). The V. harveyi BB170 mutant contains a transposon insertion in the luxN gene, which codes for the LuxN signal receptor for the AHL signal (Bassler et al. 1993). Thus V. harveyi BB170 cannot detect AHLs, but remains sensitive to the Al-2 and CAl-1 signals (Bassler et al. 1993, Henke and Bassler 2004a). In the presence of Al-2 or CAI-1, the $V$. harveyi BB170 culture will bioluminesce. The $V$. harveyi BB152 mutant carries a transposon insertion in the luxM gene which codes for the AHL signal ( $\mathrm{HAl}-1)$; thus, this strain cannot produce the $\mathrm{AHL}$ signal, but does produce the $\mathrm{Al}-2$ and $\mathrm{CAl}-1$ signals (Bassler et al. 1994). The V. harveyi strains BB170 (ATCC BAA-1117) and BB152 (ATCC BAA-1117) were obtained from the American Type Culture Collection.

\section{Vibrio harveyi BB170 Al-2 Assays}

The Al-2 assay used in this study follows the protocol developed by Taga (2005) with slight modification. A modified autoinducer bioassay $\left(A B_{V h}\right)$ medium was prepared by first 
creating a $1 \mathrm{~L}$ solution of $0.3 \mathrm{M} \mathrm{NaCl}, 0.05 \mathrm{M} \mathrm{MgSO}_{4}$, and $0.2 \%$ casamino acids which was adjusted to $\mathrm{pH} 7.5$. This solution was autoclaved $\left(121^{\circ} \mathrm{C}, 20\right.$ minutes $)$ and the following components were added to the cooled solution from sterile stocks: $0.05 \mathrm{M} \mathrm{K}_{2} \mathrm{HPO}_{4}(\mathrm{pH} 7.0)$, $0.001 \mathrm{M} \mathrm{L-arginine,}$ and glycerol (to 1.0\%). A frozen glycerol stock of the $V$. harveyi BB170 reporter strain was used to inoculate $1 \mathrm{ml}$ of $A B_{V h}$ medium, which was grown at $30^{\circ} \mathrm{C}$ with aeration and shaking until the culture was turbid and showed obvious luminescence in a darkroom. The $V$. harveyi BB170 culture was then diluted 1:5000 in fresh, sterile $\mathrm{AB}_{\mathrm{Vh}}$ medium and used to prepare the 96-well plate assay.

The CF from V. harveyi BB152 was prepared for use as a positive control in the Al-2 assay. The $V$. harveyi $\mathrm{BB} 152$ strain was cultured overnight in $\mathrm{AB}_{\mathrm{Vh}}$ medium at $30^{\circ} \mathrm{C}$ with aeration and shaking. A $1.5 \mathrm{ml}$ aliquot of the culture was centrifuged at $12,000 \mathrm{~g}$ for 10 minutes and the resulting supernatant was filter sterilized using a $0.22 \mu \mathrm{m}$ membrane filter (Millipore, Billerica, MA, USA) placed at the tip end of a sterile syringe.

The Al-2 assays were conducted in sterile 96-well microtiter plates (BD Falcon ${ }^{\mathrm{TM}} 353219$, polystyrene, black with a clear, flat bottom and lid). Each assay plate contained triplicate experimental wells, control wells, and reference wells, all with final well volumes of $100 \mu \mathrm{l}$. Table 5 shows the contents of the different well types used in the Al- 2 assay. The sample wells contained $90 \mu \mathrm{l}$ of diluted $V$. harveyi BB170 culture and $10 \mu \mathrm{l}$ of CF from the isolate under investigation. The positive control wells contained $90 \mu$ of diluted $V$. harveyi BB170 culture and $10 \mu \mathrm{l}$ of CF from $V$. harveyi BB152. The medium control wells contained $90 \mu$ l of diluted $V$. harveyi BB170 culture and $10 \mu \mathrm{l}$ of the medium used to culture the sample isolate (MB for bacterial isolates and BG11 for cyanobacteria). The blank wells contained $90 \mu \mathrm{l}$ of $\mathrm{AB}_{\mathrm{Vh}}$ medium and $10 \mu \mathrm{l}$ of the medium used to culture the sample isolate. Each assay also included reference wells for all media used in the assay $\left(A B_{V h}, M B\right.$, and/or $\left.B G 11\right)$. The prepared microtiter plates were incubated at $30^{\circ} \mathrm{C}$ with shaking during the assay. Optical density at $600 \mathrm{~nm}\left(\mathrm{OD}_{600}\right)$ and luminescence $(490 \mathrm{~nm})$ readings were conducted every 15 minutes for a period of 7 hours using 
Table 5. Experimental setup for the Al-2 assays showing the contents of each well type. The Medium Control wells were included to determine the optimal time point for the assay. The Blank well readings were used to correct the luminescence readings in the experimental wells. The Medium Reference wells were included to ensure that the MB and BG11 media were sterile. The AB ${ }_{V h}$ Medium Reference wells were included to ensure that the $A B_{V h}$ medium was sterile and to correct the luminescence readings of the positive control.

\begin{tabular}{|c|c|c|c|c|c|}
\hline Well Type & $\begin{array}{c}\text { Vol. } \boldsymbol{V} \text {. harveyi } \\
\text { BB170 Culture }(\boldsymbol{\mu l})\end{array}$ & Vol. Isolate CF $(\boldsymbol{\mu l})$ & $\begin{array}{c}\text { Vol. V. harveyi } \\
\text { BB152 CF }(\boldsymbol{\mu l})\end{array}$ & $\begin{array}{c}\text { MB or BG11 } \\
\text { Medium }(\mu \mathrm{l})\end{array}$ & $\begin{array}{c}\text { AB } \\
\text { Vh Medium }(\mu \mathrm{l})\end{array}$ \\
\hline Sample & 90 & 10 & - & - & - \\
\hline Positive Ctrl & 90 & - & 10 & - & - \\
\hline Medium Ctrl & 90 & - & - & 10 & - \\
\hline Blank & - & - & - & 10 & 90 \\
\hline Medium Reference & - & - & - & 100 & - \\
\hline $\mathrm{AB}_{\mathrm{Vh}}$ Medium Reference & - & - & - & - & 100 \\
\hline
\end{tabular}


a BioTek Synergy HT Multi-Mode Microplate Reader linked directly to a PC with Gen5 software ${ }^{\mathrm{TM}}$ (BioTek Instruments, Inc., Winooski, VT, USA).

\section{Optimal Time Point of Al-2 Assay}

Over the course of the 7-hour Al-2 assay, light production in relative luminescence units (rlu) was measured at 15-minute time intervals. In the absence of exogenous Al-2, light production in the V. harveyi BB170 culture initially decreases as any available AI-2 in the diluted V. harveyi BB170 culture is used up. Later, self-induction by V. harveyi BB170 initiates the QS response and light production increases (the $V$. harveyi BB170 Al-2 synthase luxS gene is intact and produces Al-2 during the course of the assay; Figure 1). As described by Taga (2005), Al-2 activity in the V. harveyi BB170 Al-2 assay should be determined at the optimal time point of the assay, defined as the time point immediately preceding self-induction by the $V$. harveyi BB170 reporter strain (Figure 1). For this study, the optimal time point was determined as the time at which the mean luminescence of the medium control wells was lowest during the course of the assay.

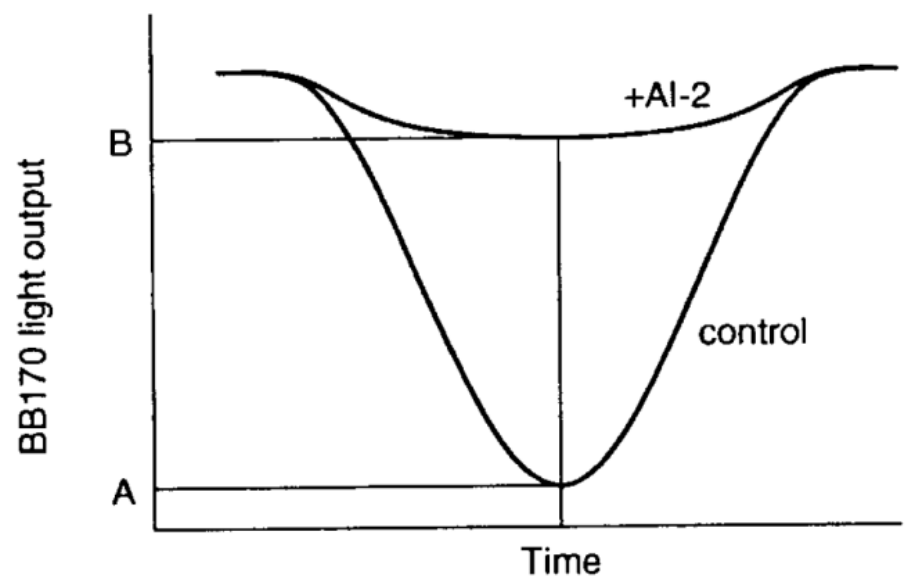

Figure 1. Light production in the Vibrio harveyi BB170 Al-2 assay over time (from Taga 2005). In the absence of exogenous Al-2 (control curve), light production initially decreases and then increases dramatically in response to autoinduction by the $V$. harveyi BB170 strain. When exogenous Al-2 is available at the start of the assay (+Al-2 curve), light production is induced at a time point prior to autoinduction by $V$. harveyi BB170. Induction of luminescence is calculated at the optimal time point (see text), marked by the vertical line. 


\section{Percentage of Al-2 activity}

The percentage of $\mathrm{Al}-2(\% \mathrm{Al}-2)$ activity is expressed as a percentage of the positive control luminescence at the optimal time point in the V. harveyi BB170 Al-2 assay (Bodor et al. 2008). The \%Al-2 activity was calculated as the fold induction of the sample divided by fold induction of the positive control, as shown below.

$$
\% \text { AI }-2 \text { Activity }=\frac{\text { Fold Induction of sample }}{\text { Fold Induction of pos ctrl }}=\frac{\text { Lum of sample } / \text { Lum of } \text { ref }_{\text {sample }}}{\text { Lum of posl } / \text { Lum of ref } \text { pos ctrl }_{\text {L }}}
$$

The fold induction of the sample was calculated as a fold change between the sample luminescence and the corresponding reference luminescence (MB for the bacterial CFs and BG11 medium for the cyanobacterial CFs). The fold induction of the positive control was calculated as a fold change between the positive control luminescence and the corresponding reference luminescence $\left(A B_{V h}\right.$ medium for the positive control $\left.C F\right)$.

\section{Induction of Luminescence}

The luminescence for each sample at the optimal time point was used to calculate the induction of luminescence, which is expressed as a fold induction of the sample in comparison to the luminescence of the positive control. The induction of luminescence was calculated by dividing the sample luminescence by the positive control luminescence at the optimal time point (Taga 2005; Han and Lu 2009).

\section{Bacterial Growth Challenges}

Bacterial constituents of the BBD and coral SML communities may produce secondary metabolites that inhibit or stimulate the growth of other BBD and SML bacteria. Specific bacterial isolate CFs were used to challenge target cultures of BBD and SML isolates. The isolates selected for the bacterial growth challenges included all nine isolates that tested positive for AHL production (i.e., positive results for the two $\mathrm{AHL}$ reporter strain assays). In addition, 10 isolates were randomly selected from the pool of isolates that tested negative for quorum sensing in all three QS assays used in this study. 
The bacterial growth challenges were conducted in sterile 96-well microtiter plates (BD Falcon 353219, polystyrene, clear with a flat bottom and lid). Each bacterial isolate to be tested was cultured in sterile $\mathrm{MB}$ overnight at $29^{\circ} \mathrm{C}$ (shaking) and then added to the appropriate wells. Each assay plate contained triplicate experimental wells, control wells, and blank wells (Table 6), as well as a single reference well for each CF tested. The CF Reference well was included to ensure that the CFs were sterile. The prepared microtiter plates were incubated at $29^{\circ} \mathrm{C}$ with shaking. Optical density readings at $600 \mathrm{~nm}$ were conducted every $30-60$ minutes using the Modulus $^{\mathrm{TM}}$ Microplate Multimode Reader until the bacterial isolate culture control reached stationary phase. The mean growth rate constant $(\mu)$ and mean generation time $(g)$ were calculated over the linear portion of the growth curve for the untreated control culture as well as the experimental treatments.

$$
\begin{gathered}
\mu=\frac{\ln \left(O D_{2}\right)-\ln \left(O D_{1}\right)}{t_{2}-t_{1}} \\
g=\frac{\ln (2)}{\mu}
\end{gathered}
$$

Table 6. Experimental setup for the growth challenge assays showing the contents of each well type. The Culture Filtrate (CF) Reference well was monitored to ensure that the filtration step successfully removed all cells. The Blank wells were monitored to ensure the MB medium was sterile.

\begin{tabular}{|c|c|c|c|c|}
\hline Well Type & $\begin{array}{c}\text { No. Replicate } \\
\text { Wells }\end{array}$ & $\begin{array}{c}\text { Vol. Bacterial } \\
\text { Culture }(\mu \mathrm{l})\end{array}$ & $\begin{array}{c}\text { Vol. Marine } \\
\text { Broth }(\boldsymbol{\mu l})\end{array}$ & Vol. Test CF $(\boldsymbol{\mu l})$ \\
\hline Experimental & 3 & 5 & 90 & 5 \\
\hline Ctrl & 3 & 5 & 95 & - \\
\hline CF Reference & 1 & - & 95 & 5 \\
\hline Blank & 3 & - & 100 & - \\
\hline
\end{tabular}




\section{Sequencing of the 16S rRNA Gene of Bacterial Isolates}

Genomic DNA from the nine isolates that tested positive for AHL production (i.e., positive results for the Chromobacterium violaceum CV026 and Agrobacterium tumefaciens NTL4(pZLR4) assays) were extracted either by conducting a simple cell pop or by the bead-beating method using the FastDNA SPIN kit for soil (Q-Biogene). For the cell pop method, the isolate of interest was streaked on MB agar and a single colony was collected with a sterile loop and added to an Eppendorf tube containing $100 \mu \mathrm{l}$ of sterile 1X phosphate buffered saline (PBS). The tubes were heated to $99^{\circ} \mathrm{C}$ for 10 minutes and then centrifuged at $5,000 \times \mathrm{g}$ for 10 minutes. For the beadbeating method, the manufacturer's instructions were followed when using the FastDNA SPIN kit for soil. The DNA extracts were amplified by polymerase chain reaction (PCR) using the universal bacterial primers 27F (5'-AGA GTT TGA TCM TGG CTC AG-3') and 1492R (5'-TAC GGY TAC CTT GTT ACG ACT T-3') (Muyzer et al. 1995; Integrated DNA technologies, Coralville, IA) in a Peltier Thermal Cycler (PTC-200, MJ Research, Waltham, MA). The PCR mixtures contained 1X PCR buffer, $2.5 \mathrm{mM} \mathrm{MgCl}$, $0.5 \mathrm{U}$ AmpliTaq Gold DNA polymerase (Applied Biosystems, Foster City, CA), 0.1\% (wt/vol) bovine serum albumin (fraction V; Fisher, Suwannee, GA), $0.25 \mathrm{mM}$ concentrations of each deoxynucleoside triphosphate (Promega, Madison, WI), 0.5 $\mu \mathrm{M}$ forward and reverse primers, and $10 \mathrm{ng}$ of genomic DNA, and the final volume was brought to $20 \mu$ with nuclease-free water (Fisher, Suwannee, GA). The PCR program consisted of a hotstart $\left(95^{\circ} \mathrm{C}\right.$ for 10 minutes), followed by 24 cycles of $95^{\circ} \mathrm{C}$ for 1 minute, $54^{\circ} \mathrm{C}$ for 2 seconds, and $72^{\circ} \mathrm{C}$ for 2 minutes, a final extension step of $72^{\circ} \mathrm{C}$ for 10 minutes, and storage at $4^{\circ} \mathrm{C}$. The PCR products were verified by electrophoresis on an agarose $(1.8 \%)$ gel with GelRed $^{\mathrm{TM}}$ stain and exposure to UV light with a FOTO/Analyst Imaging System (FOTODYNE Inc., Hartland, Wisconsin, USA). The DNA was diluted to $10 \mathrm{ng} / \mu$ l following quantification in a Bio-Rad Qubit $\circledast$ 2.0 Fluorometer. The amplified bacterial 16S rDNA was cleaned using an ExoSAP-IT ${ }^{\mathrm{TM}} \mathrm{PCR}$ cleanup kit (USB Corp., Cleveland, Ohio) and sequenced with an ABI Prism ${ }^{\mathrm{TM}} 3100$ genetic analyzer (Applied Biosystems) at the DNA Core Facility at Florida International University using the BigDye ${ }^{\circledR}$ Terminator version 3.1 (Applied Biosystems) with the 27F and 1492R primers. 
The sequences were trimmed, cleaned, aligned, and assembled using DNA Baser Sequence Assembler (v3.2.5). The nearly full-length sequences were then analyzed using the basic local alignment tool (BLAST) queuing system (www.ncbi.nlm.nih.gov/BLAST/) (Altschul et al. 1990) to identify their closest relatives in GenBank and their tentative phylogenetic positions. Clustal Omega (Sievers et al. 2011) was used to develop multiple sequence alignments. A neighbor joining tree was created using the Molecular Evolutionary Genetics Analysis (MEGA) software (v5.05) (Tamura et al. 2011). A bootstrap analysis (500 repetitions) was performed to estimate the confidence of the 16S rRNA gene tree topology. 


\section{RESULTS}

A total of nine BBD mat samples and 153 bacterial isolates were examined in this study. From the BBD and SML samples collected for this investigation, 136 bacteria were isolated, including 54 isolates from the BBD mat, 37 isolates from the SML of BBD-infected coral colonies, and 45 isolates from the SML of apparently healthy neighbor colonies (Table 7). Seventeen additional bacteria that were previously isolated from BBD (eight cyanobacteria and nine bacteria) were also examined in this thesis. These 17 isolates are in culture in the laboratory of Dr. Laurie Richardson (Florida International University, Miami, FL, USA).

\section{Acyl Homoserine Lactone Quorum Sensing Assays}

All nine BBD mat samples that were collected tested positive in both the Chromobacterium violaceum CV026 assay and the Agrobacterium tumefaciens NTL4(pZLR4) assay. These results indicate that AHL signals are present within the active BBD mat (example shown in Figure 2A). In addition, nine of the 153 bacterial isolates were shown to produce AHLs (summarized in Table 8). Two of the 153 isolates (1.3\%), BBD-FTL-6j and BBD-FTL-8c, produced a positive result in the $C$. violaceum CV026 assay, as well as the $A$. tumefaciens NTL4(pZLR4) assay. These two isolates, which were obtained from BBD mat samples located on two separate coral colonies, produced a positive patch test result in the C. violaceum CV026 assay, indicating that they produce short-chain AHLs when grown as a surface culture. None of the isolate CFs tested positive in the C. violaceum CV026 assay.

Nine of the 153 isolates $(5.9 \%)$ produced a positive result in the $A$. tumefaciens NTL4(pZLR4) assay (Table 8; Figure 2B). Of these nine bacteria, three were isolated from BBD mat samples collected from three separate coral colonies, two were isolated from SML collected from two infected coral colonies, and four were isolated from SML collected from two apparently healthy coral colonies (Table 8). Seven of the nine isolates tested positive in the A. tumefaciens NTL4(pZLR4) patch test, indicating that these isolates produce medium- to long-chain AHLs when grown on marine agar. Five of these isolates, plus an additional two (see Table 8) tested positive in the A. tumefaciens NTL4(pZLR4) CF assay, indicating production of detectable AHLs 
Table 7. The names of the 136 bacteria isolated for this study. Names are listed according to isolate type and individual colony. BBD: black band disease mat; BSML: surface mucopolysaccharide layer from BBD-infected coral colony; HSML: surface mucopolysaccharide layer from apparently healthy coral colony. Additional colony information is provided in Table 1.

\begin{tabular}{|c|c|c|c|}
\hline & \multicolumn{3}{|c|}{ Isolate Type } \\
\hline Colony No. & BBD Isolates & BSML Isolates & HSML Isolates \\
\hline FTL 1 & \begin{tabular}{|l|} 
BBD-FTL-1a \\
BBD-FTL-1b \\
BBD-FTL-1c \\
BBD-FTL-1d \\
BBD-FTL-1e \\
BBD-FTL-1f \\
BBD-FTL-1g \\
BBD-FTL-1h \\
BBD-FTL-1j \\
BBD-FTL-1k \\
BBD-FTL-1l \\
BBD-FTL-1m
\end{tabular} & - & - \\
\hline FTL 2 & $\begin{array}{l}\text { BBD-FTL-2a } \\
\text { BBD-FTL-2b } \\
\text { BBD-FTL-2c }\end{array}$ & - & - \\
\hline FTL 3 & \begin{tabular}{|l|} 
BBD-FTL-3b \\
BBD-FTL-3g \\
BBD-FTL-3h \\
BBD-FTL-3j
\end{tabular} & - & - \\
\hline FTL 4 & BBD-FTL-4b & - & - \\
\hline FTL 5 & $\begin{array}{l}\text { BBD-FTL-5d } \\
\text { BBD-FTL-5f }\end{array}$ & - & - \\
\hline FTL 6 & $\begin{array}{l}\text { BBD-FTL-6b } \\
\text { BBD-FTL-6c } \\
\text { BBD-FTL-6d } \\
\text { BBD-FTL-6f } \\
\text { BBD-FTL-6g } \\
\text { BBD-FTL-6h } \\
\text { BBD-FTL-6i } \\
\text { BBD-FTL-6j } \\
\text { BBD-FTL-6k } \\
\text { BBD-FTL-6l } \\
\text { BBD-FTL-6m } \\
\text { BBD-FTL-6n } \\
\text { BBD-FTL-6o } \\
\text { BBD-FTL-6p } \\
\text { BBD-FTL-6q }\end{array}$ & \begin{tabular}{|l} 
BSML-FTL-6r \\
BSML-FTL-6s \\
BSML-FTL-6t \\
BSML-FTL-6u \\
BSML-FTL-6v \\
BSML-FTL-6w \\
BSML-FTL-6x
\end{tabular} & - \\
\hline FTL 7 & $\begin{array}{l}\text { BBD-FTL-7a } \\
\text { BBD-FTL-7b }\end{array}$ & $\begin{array}{l}\text { BSML-FTL-7a } \\
\text { BSML-FTL-7c } \\
\text { BSML-FTL-7d } \\
\text { BSML-FTL-7e } \\
\text { BSML-FTL-7f } \\
\text { BSML-FTL-7h } \\
\text { BSML-FTL-7j } \\
\text { BSML-FTL-7k } \\
\text { BSML-FTL-7l } \\
\text { BSML-FTL-7m } \\
\text { BSML-FTL-7n } \\
\text { BSML-FTL-7o } \\
\text { BSML-FTL-7q }\end{array}$ & - \\
\hline FTL 8 & \begin{tabular}{|l|} 
BBD-FTL-8b \\
BBD-FTL-8c
\end{tabular} & $\begin{array}{l}\text { BSML-FTL-8a } \\
\text { BSML-FTL-8b } \\
\text { BSML-FTL-8c }\end{array}$ & - \\
\hline
\end{tabular}

\begin{tabular}{|c|c|c|c|}
\hline & \multicolumn{3}{|c|}{ Isolate Type } \\
\hline Colony No. & BBD Isolates & BSML Isolates & HSML Isolates \\
\hline FTL 9 & - & - & $\begin{array}{l}\text { HSML-FTL-9a } \\
\text { HSML-FTL-9b } \\
\text { HSML-FTL-9c } \\
\text { HSML-FTL-9d } \\
\text { HSML-FTL-9e } \\
\text { HSML-FTL-9f } \\
\text { HSML-FTL-9g } \\
\text { HSML-FTL-9i } \\
\text { HSML-FTL-9j } \\
\text { HSML-FTL-9k } \\
\text { HSML-FTL-9l } \\
\text { HSML-FTL-9m }\end{array}$ \\
\hline FTL 10 & - & - & $\begin{array}{l}\text { HSML-FTL-10a } \\
\text { HSML-FTL-10c } \\
\text { HSML-FTL-10d } \\
\text { HSML-FTL-10f } \\
\text { HSML-FTL-10g } \\
\text { HSML-FTL-10k } \\
\text { HSML-FTL-10I } \\
\text { HSML-FTL-10n } \\
\text { HSML-FTL-10o } \\
\text { HSML-FTL-10p } \\
\text { HSML-FTL-10q } \\
\text { HSML-FTL-10r } \\
\text { HSML-FTL-10s } \\
\text { HSML-FTL-10t } \\
\text { HSML-FTL-10u } \\
\text { HSML-FTL-10v } \\
\text { HSML-FTL-10x } \\
\text { HSML-FTL-10z } \\
\text { HSML-FTL-10aa } \\
\text { HSML-FTL-10bb }\end{array}$ \\
\hline FTL 11 & - & - & $\begin{array}{l}\text { HSML-FTL-11a } \\
\text { HSML-FTL-11b } \\
\text { HSML-FTL-11c } \\
\text { HSML-FTL-11e } \\
\text { HSML-FTL-11f } \\
\text { HSML-FTL-11g } \\
\text { HSML-FTL-11h } \\
\text { HSML-FTL-11i } \\
\text { HSML-FTL-11j } \\
\text { HSML-FTL-11k } \\
\text { HSML-FTL-11l } \\
\text { HSML-FTL-11m } \\
\text { HSML-FTL-11o } \\
\end{array}$ \\
\hline FLK 1 & $\begin{array}{l}\text { BBD-FLK-1a } \\
\text { BBD-FLK-1b } \\
\text { BBD-FLK-1c } \\
\text { BBD-FLK-1d } \\
\text { BBD-FLK-1e } \\
\text { BBD-FLK-1f } \\
\text { BBD-FLK-1h } \\
\text { BBD-FLK-1i } \\
\text { BBD-FLK-1j } \\
\text { BBD-FLK-1k } \\
\text { BBD-FLK-1l } \\
\text { BBD-FLK-1m } \\
\text { BBD-FLK-1n }\end{array}$ & $\begin{array}{l}\text { BSML-FLK-1a } \\
\text { BSML-FLK-1b } \\
\text { BSML-FLK-1c } \\
\text { BSML-FLK-1d } \\
\text { BSML-FLK-1e } \\
\text { BSML-FLK-1f } \\
\text { BSML-FLK-1h } \\
\text { BSML-FLK-1i } \\
\text { BSML-FLK-1j } \\
\text { BSML-FLK-1k } \\
\text { BSML-FLK-1I } \\
\text { BSML-FLK-1m } \\
\text { BSML-FLK-1n } \\
\text { BSML-FLK-10 }\end{array}$ & - \\
\hline
\end{tabular}




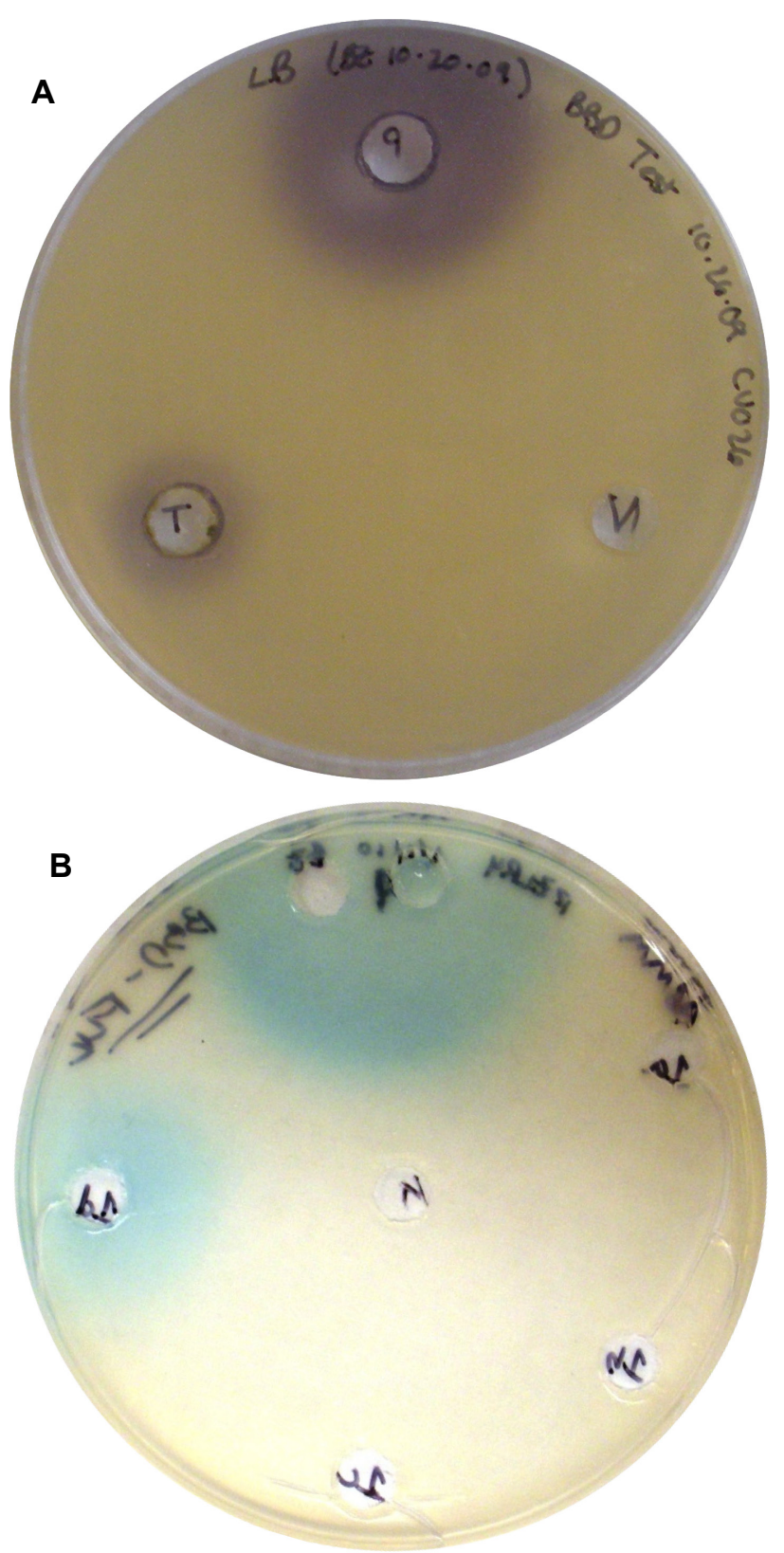

Figure 2. Positive results in colorimetric AHL assay plates; (A) Chromobacterium violaceum CV026 assay plate, showing a positive result (left) obtained from a BBD mat sample ; (B) Agrobacterium tumefaciens NTL4(pZLR4) assay plate showing a positive result (left) with the cellfree culture filtrate from BBD-FLK-1d. Positive control wells are located at the top of each plate. 
Table 8. Bacterial isolates that tested positive for acyl homoserine lactone (AHL) production using the Chromobacterium violaceum $\mathrm{CV} 026$ and/or Agrobacterium tumefaciens NTL4(pZLR4) assays. CF: cell-free culture filtrate; BBD: black band disease; SML: surface mucopolysaccharide layer.

\begin{tabular}{|c|c|c|c|c|c|c|}
\hline \multirow[b]{2}{*}{ Isolate Name } & \multirow[b]{2}{*}{ Sample Source } & \multirow[b]{2}{*}{ Coral Species } & \multicolumn{2}{|c|}{$\begin{array}{c}\text { Chromobacterium } \\
\text { violaceum CV026 } \\
\text { Assay }\end{array}$} & \multicolumn{2}{|c|}{$\begin{array}{c}\text { Agrobacterium } \\
\text { tumefaciens NTL4(pZLR4) } \\
\text { Assay } \\
\end{array}$} \\
\hline & & & Patch Test & CF Test & Patch Test & CF Assay \\
\hline BBD-FTL-6j & BBD Mat & Montastraea cavernosa & Pos & Neg & Neg & Pos \\
\hline BBD-FTL-8c & BBD Mat & Montastraea cavernosa & Pos & $\mathrm{Neg}$ & $\mathrm{Neg}$ & Pos \\
\hline BBD-FLK-1d & BBD Mat & Diploria strigosa & $\mathrm{Neg}$ & $\mathrm{Neg}$ & Pos & Pos \\
\hline BSML-FTL-6w & SML (BBD-infected coral) & Montastraea cavernosa & $\mathrm{Neg}$ & $\mathrm{Neg}$ & Pos & $\mathrm{Neg}$ \\
\hline BSML-FTL-7I & SML (BBD-infected coral) & Montastraea cavernosa & $\mathrm{Neg}$ & $\mathrm{Neg}$ & Pos & Neg \\
\hline HSML-FTL-9c & SML (healthy coral) & Diploria strigosa & $\mathrm{Neg}$ & $\mathrm{Neg}$ & Pos & Pos \\
\hline HSML-FTL-9e & SML (healthy coral) & Diploria strigosa & $\mathrm{Neg}$ & Neg & Pos & Pos \\
\hline HSML-FTL-9i & SML (healthy coral) & Diploria strigosa & $\mathrm{Neg}$ & $\mathrm{Neg}$ & Pos & Pos \\
\hline HSML-FTL-10a $^{1}$ & SML (healthy coral) & Montastraea cavernosa & $\mathrm{Neg}$ & $\mathrm{Neg}$ & Pos & Pos \\
\hline
\end{tabular}

${ }^{1}$ Note: Isolate HSML-FTL-10a produced a dark purple pigment. 
when cultured in marine broth. None of the eight cyanobacterial isolates produced a positive result in either the C. violaceum CV026 or the A. tumefaciens NTL4(pZLR4) assays.

It should be noted that 15 isolates inhibited the growth of the Chromobacterium violaceum CV026 reporter strain during the patch test and/or CF assays (Table 9). Growth inhibition was visible in the form of a ring of clear, cell-free agar in the C. violaceum CV026 assay plates surrounding the bacterial patch and/or the well containing the isolate CF. Two of these 15 isolates (BSML-FTL-7I and HSML-FTL-10a) also tested positive for AHL production in the $A$. tumefaciens NTL4(pZLR4) assay (see Tables 8 and 9). Seven of the isolates inhibited growth of the Vibrio harveyi BB170 reporter strain; of these, six also inhibited C. violaceum CV026 (Table 9). The cloudy nature of the $A B_{V h}$ agar precluded detection of growth inhibition in the $A$. tumefaciens NTL4(pZLR4) reporter strain.

Nearly full-length 16S rRNA gene sequences were obtained for the nine isolates that tested positive for $\mathrm{AHL}$ production. Table 10 presents the length of the sequences obtained, along with the closest relative results from the BLAST search. Figure 3 presents a phylogenetic tree for the AHL-producing isolates that was constructed using the 16S rRNA gene sequences.

\section{Autoinducer-2 Quorum Sensing Assays}

The percentage of $\mathrm{Al}-2$ (\%Al-2) activity and the induction of luminescence were calculated for each sample. The \%AI-2 activity is expressed as a percentage of the positive control luminescence at the optimal time point of the Al-2 assay. The fold induction values are expressed as an ( $n$-fold) induction over the positive control luminescence at the optimal time point of the assay. For the Al-2 assay in this study, a positive result is defined as a \%Al-2 activity of $\geq 25 \%$. This $25 \%$ Al-2 activity cut-off value was determined based on the luminescence curves generated, with Al-2 positive CFs more closely following the luminescence curve of the positive control and Al-2 negative CFs more closely following the medium control curve. Results of a representative experiment testing the response of the CFs of four isolates are shown in Figure 4. 
Table 9. Growth inhibition of the Chromobacterium violaceum CV026 and/or Vibrio harveyi BB170 reporter strains observed in the patch test and $\mathrm{CF}$ assays. Bolded isolates were positive for AHL production (Table 7).

\begin{tabular}{|c|c|c|c|c|c|}
\hline \multirow[b]{2}{*}{ Isolate Name } & \multirow[b]{2}{*}{ Sample Source } & \multirow[b]{2}{*}{ Coral Species } & \multicolumn{2}{|c|}{$\begin{array}{c}\text { Inhibition of } \\
\text { Chromobacterium violaceum } \\
\text { CV026 Growth }\end{array}$} & \multirow[t]{2}{*}{$\begin{array}{l}\text { Inhibition of Vibrio } \\
\text { harveyi BB170 Growth }\end{array}$} \\
\hline & & & Patch Test & CF Test & \\
\hline BBD-FLK-1b & BBD Mat & Diploria strigosa & Pos & - & - \\
\hline BBD-FLK-1c & BBD Mat & Diploria strigosa & Pos & - & - \\
\hline BBD-FLK-1h & BBD Mat & Diploria strigosa & Pos & - & - \\
\hline BBD-FLK-1k & BBD Mat & Diploria strigosa & Pos & - & - \\
\hline BBD-FTL-5d & BBD Mat & Montastraea cavernosa & - & - & Pos \\
\hline BSML-FTL-7a & SML (BBD-infected coral) & Montastraea cavernosa & - & Pos & Pos \\
\hline BSML-FTL-7j & SML (BBD-infected coral) & Montastraea cavernosa & Pos & Pos & - \\
\hline BSML-FTL-7I & SML (BBD-infected coral) & Montastraea cavernosa & Pos & - & - \\
\hline BSML-FLK-1C & SML (BBD-infected coral) & Diploria strigosa & Pos & - & - \\
\hline HSML-FTL-10a & SML (healthy coral) & Montastraea cavernosa & Pos & - & Pos \\
\hline HSML-FTL-10c & SML (healthy coral) & Montastraea cavernosa & Pos & - & Pos \\
\hline HSML-FTL-10f & SML (healthy coral) & Montastraea cavernosa & Pos & - & Pos \\
\hline HSML-FTL-10q & SML (healthy coral) & Montastraea cavernosa & Pos & - & Pos \\
\hline HSML-FTL-11c & SML (healthy coral) & Montastraea cavernosa & Pos & - & - \\
\hline HSML-FTL-11e & SML (healthy coral) & Montastraea cavernosa & - & Pos & Pos \\
\hline
\end{tabular}


Table 10. Identity of the nine isolates that produce AHL signals. The length of the $16 \mathrm{~S}$ rRNA gene sequence is presented, along with the information regarding the closest relative derived from a BLAST search, including the percent similarity and accession number.

\begin{tabular}{|l|c|l|l|}
\cline { 3 - 4 } \multicolumn{1}{l|}{} & \multicolumn{2}{c|}{ Name (\% Similarity) } & Accession No. \\
\hline Isolate Name & Sequence Length (bp) & \multicolumn{1}{|c|}{ NR042081 } \\
\hline BBD-FTL-6j & 1393 & Vibrio rotiferianus strain : LMG 21460 (99\%) & NR042081 \\
\hline BBD-FTL-8c & 1415 & Vibrio rotiferianus strain : LMG 21460 (99\%) & NR042673 \\
\hline BSML-FTL-6w & 1326 & Nautella italica strain : LMG 24365 (99\%) & NR042675 \\
\hline BSML-FTL-7I & 1385 & Ruegeria scottomollicae : LMG 24367 (96\%) & NR028809 \\
\hline HSML-FTL-9c & 1414 & Pseudoalteromonas phenolica strain O-BC30 (98\%) & NR043165 \\
\hline HSML-FTL-9e & 1398 & Vibrio harveyi strain NCIMB1280 (99\%) & NR044585 \\
\hline HSML-FTL-9i & 1345 & Pseudoruegeria aquimaris strain SW-255 (96\%) & NR043932 \\
\hline HSML-FTL-10a & 1387 & Pseudoalteromonas luteoviolacea strain NCIMB 1893 (99\%) & NR026221 \\
\hline
\end{tabular}




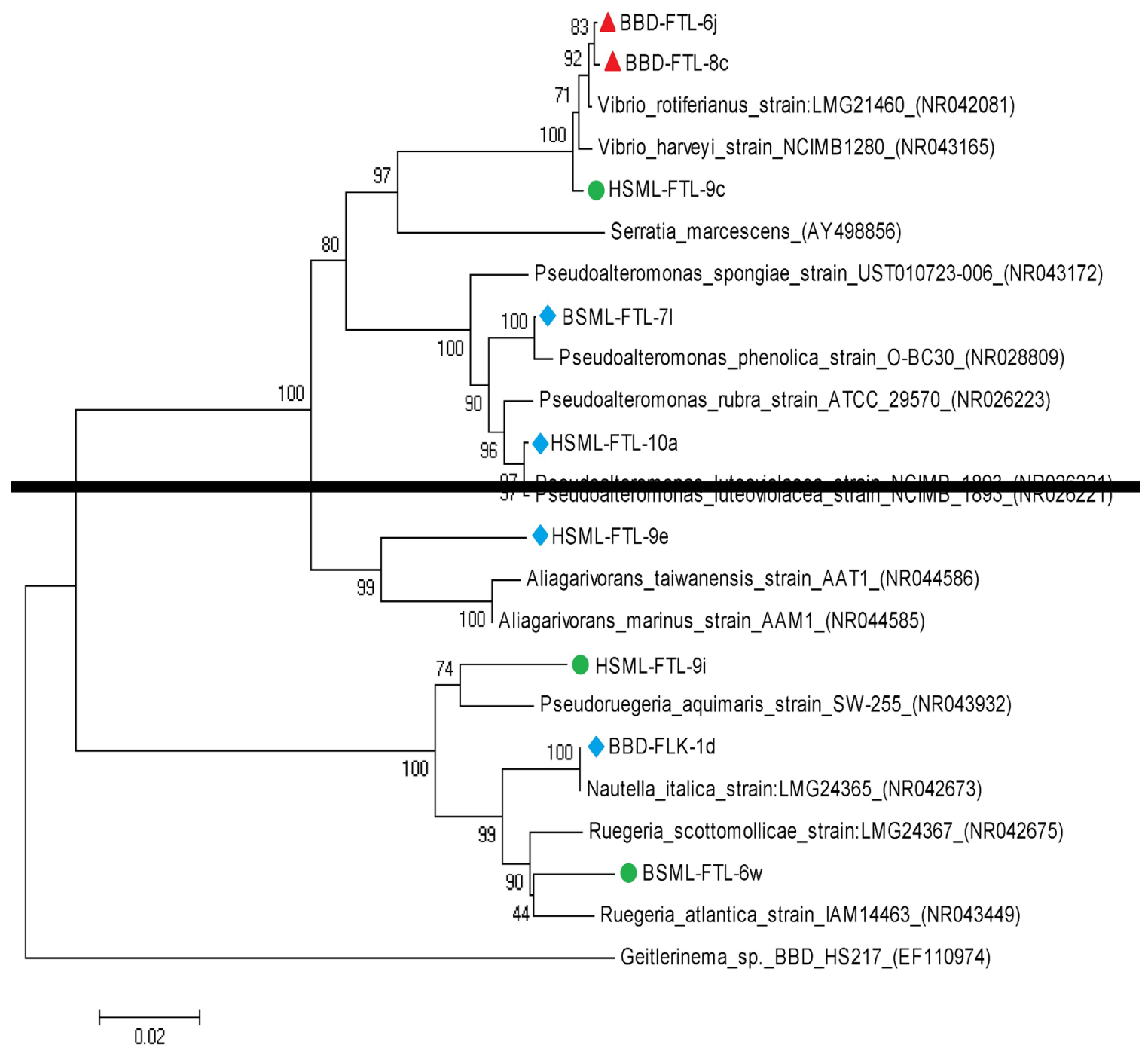

Figure 3. A phylogenetic tree of the nine AHL-producing isolates, together with the best-matched sequences from the GenBank. Bootstrap probabilities are indicated at the branch nodes. The scale bar represents five substitutions per 100 nucleotide positions. GenBank accession numbers are provided in parentheses. Symbols: $\diamond$ isolates tested positive for AHL production in the Agrobacterium tumefaciens NTL4(pZLR4) assay; $\quad$ isolates tested positive for AHL and Al-2 production in the A. tumefaciens NTL4(pZLR4) and Vibrio harveyi BB170 assay; $\quad$ isolates tested positive for $\mathrm{AHL}$ and $\mathrm{Al}-2$ production in the Chromobacterium violaceum CV026, $A$. tumefaciens NTL4(pZLR4), and V. harveyi BB170 assays. 


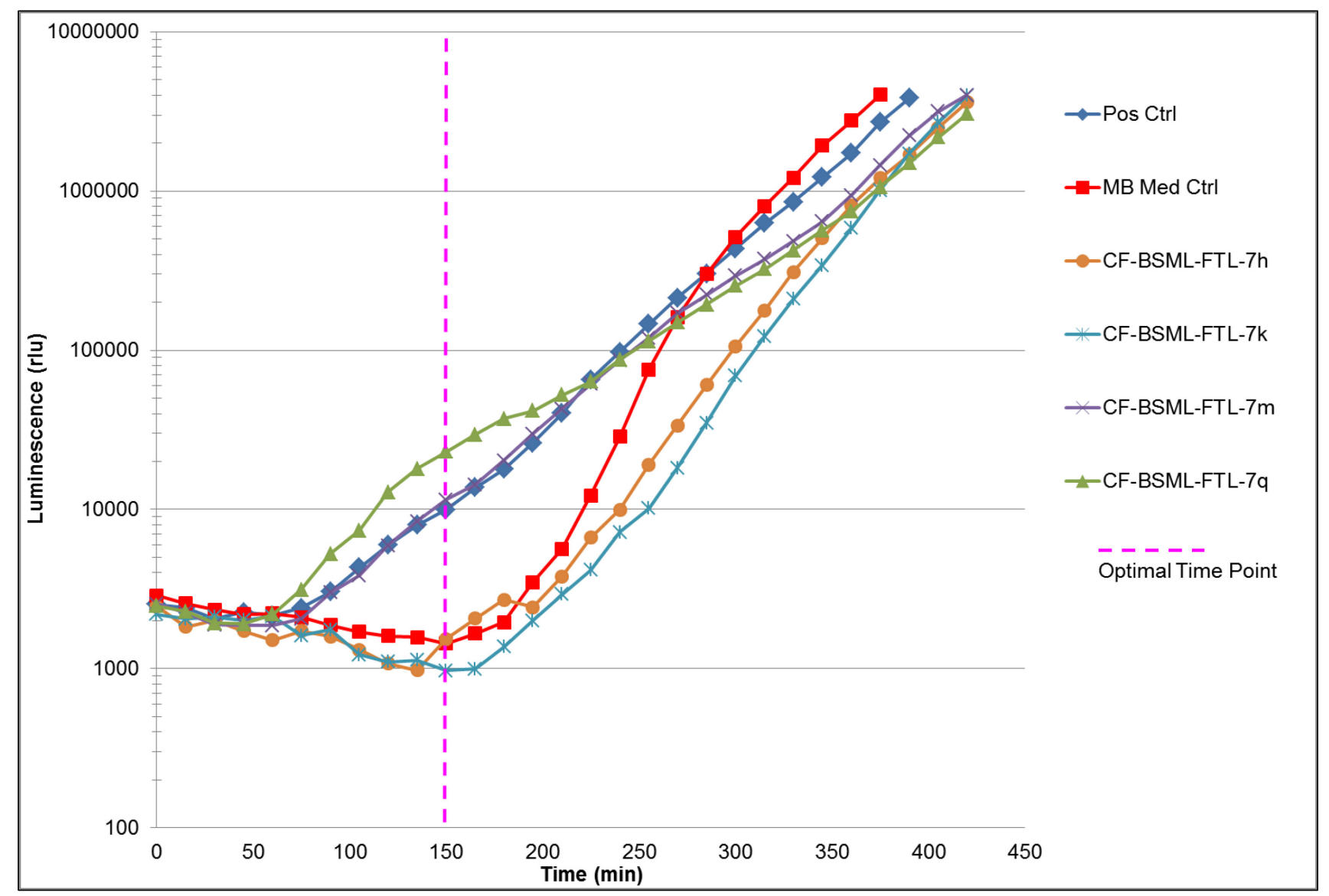

Figure 4. Representative experiment showing light production over time in the Al-2 assay. The curves generated by the cell-free culture filtrates (CFs) from BSML-FTL-7m and BSML-FTL-7q (both positive in the Al-2 assay) follow the positive control curve. The curves generated by the CFs from BSML-FTL-7h and BSML-FTL-7k (both negative in the Al-2 assay) follow the Marine Broth (MB) medium control curve. Dashed vertical line indicates the optimal time point of the assay. 
Of the 153 CFs investigated in this study, more than half (i.e., 84 CFs or $\sim 55 \%$ ) produced a positive result in the Al-2 assay. These data indicate that the $84 \mathrm{CFs}$ that tested positive contain Al-2-like molecules (or the CAl-1 signal specific to certain Vibrio spp.) that can be detected by the Vibrio harveyi BB170 reporter strain. The \%Al-2 activity for these CFs ranged widely, from approximately $28.2 \%-345.8 \%$ of the positive control luminescence. Table 11 summarizes the \%Al-2 activity for the $84 \mathrm{CFs}$ that tested positive in the $\mathrm{Al}-2$ assay. The triplicate readings for the $\mathrm{Al}-2$ positive test strains were within $30 \%$ of the mean luminescence values (rlu) shown in Table 11. In addition to the \%Al-2 activity, the induction of luminescence over the positive control was calculated for each CF tested. The 84 CFs produced a luminescence range from $0.22-2.81$ (Table 11) and five CFs also tested positive in the AHL assays: BBD-FTL-6j, BBD-FTL-8c, BSML-FTL-6w, HSML-FTL-9c, and HSML-FTL-9i.

As shown in Table 12, the CFs of isolates from the BBD mat accounted for $52 \%$ of the 84 (total) positive results from the $\mathrm{Al}-2$ assay. Of the $63 \mathrm{CFs}$ from $\mathrm{BBD}$ isolates that were examined, $70 \%$ tested positive. The CFs of isolates from the SML of BBD-infected colonies accounted for $30 \%$ of the Al-2 positive results, and $68 \%$ of the 37 BSML CFs tested positive. Culture filtrates of isolates from the SML of apparently healthy corals comprised $18 \%$ of the positive Al-2 results and one-third of the 45 HSML CFs tested were positive. None of the cyanobacterial CFs tested positive in the Al-2 assay. The \%Al-2 activity for these CFs ranged from approximately $<1.0 \%-$ $23.7 \%$ of the positive control luminescence. For the CFs that tested negative in the Al-2 assay, the values for induction over the positive control luminescence ranged from $0.01-0.21$. 


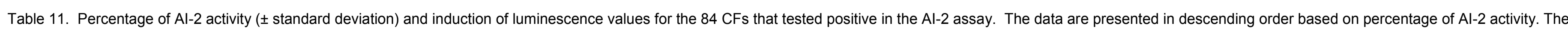
induction of luminescence was calculated by dividing the sample luminescence by the positive control luminescence at the optimal time point.

\begin{tabular}{|c|c|c|}
\hline Isolate CF & $\begin{array}{c}\text { \% Al-2 Activity } \\
( \pm \text { SD) }\end{array}$ & $\begin{array}{c}\text { Induction of } \\
\text { Luminescence }\end{array}$ \\
\hline BBD-216-1b & $345.84 \pm 21.64$ & $\begin{array}{r}2.70 \\
\end{array}$ \\
\hline BBD-FTL-6j & $275.70 \pm 50.29$ & 2.15 \\
\hline HSML-FTL-11b & $275.28 \pm 8.36$ & 2.81 \\
\hline BBD-FLK-1h & $271.58 \pm 53.24$ & 2.12 \\
\hline BBD-FLK-1k & $260.04 \pm 31.05$ & 2.03 \\
\hline HSML-FTL-10bb & $256.29 \pm 14.77$ & 2.62 \\
\hline BSML-FTL-7q & $232.11 \pm 12.81$ & 2.32 \\
\hline BSML-FLK-1C & $226.54 \pm 12.24$ & 2.26 \\
\hline HSML-FTL-9f & $213.76 \pm 16.11$ & 1.70 \\
\hline HSML-FTL-9d & $200.67 \pm 11.94$ & 1.60 \\
\hline HSML-FTL-11i & $191.23 \pm 10.64$ & 1.96 \\
\hline HSML-FTL-10z & $188.15 \pm 5.13$ & 1.92 \\
\hline HSML-FTL-10aаa & $173.52 \pm 12.67$ & 1.77 \\
\hline BBD-FLK-1b & $173.11 \pm 26.42$ & 1.35 \\
\hline BBD-FTL-6g & $167.57 \pm 16.47$ & 1.31 \\
\hline HSML-FTL-9m & $156.74 \pm 7.91$ & 1.25 \\
\hline BBD-FLK-1m & $148.82 \pm 22.84$ & 1.16 \\
\hline HSML-FTL-9a & $146.16 \pm 10.97$ & 1.16 \\
\hline HSML-FTL-9b & $144.32 \pm 14.36$ & 1.15 \\
\hline BSML-FTL-7e & $143.00 \pm 17.86$ & 1.71 \\
\hline BBD-FTL-3b & $140.38 \pm 4.35$ & 1.10 \\
\hline BSML-FLK-1e & $132.75 \pm 7.79$ & 1.32 \\
\hline BBD-FTL-8b & $127.81 \pm 9.08$ & 1.53 \\
\hline HSML-FTL-9j & $127.21 \pm 8.97$ & 1.01 \\
\hline BBD-FTL-3j & $122.89 \pm 5.15$ & 1.18 \\
\hline BBD-FTL-1j & $122.04 \pm 3.40$ & 1.46 \\
\hline BSML-FTL-8c & $121.85 \pm 6.18$ & 1.22 \\
\hline BSML-FTL-8a & $121.47 \pm 4.81$ & 1.21 \\
\hline
\end{tabular}

\begin{tabular}{|l|c|r|}
\hline Isolate CF & $\begin{array}{c}\% \text { Al-2 Activity } \\
( \pm \text { SD) }\end{array}$ & $\begin{array}{c}\text { Induction of } \\
\text { Luminescence }\end{array}$ \\
\hline BBD-FTL-6c & $120.89 \pm 21.36$ & 0.94 \\
\hline BSML-FLK-1i & $117.61 \pm 11.75$ & 1.17 \\
\hline BBD-FTL-1g & $116.64 \pm 4.84$ & 1.40 \\
\hline BSML-FTL-7m & $115.50 \pm 20.75$ & 1.15 \\
\hline BSML-FLK-1k & $115.34 \pm 11.16$ & 1.15 \\
\hline BBD-FTL-6m & $111.42 \pm 11.34$ & 1.07 \\
\hline BBD-FTL-6b & $111.03 \pm 27.91$ & 0.87 \\
\hline BBD-216-2d & $110.58 \pm 7.23$ & 1.07 \\
\hline BBD-FLK-1n & $109.27 \pm 15.53$ & 0.85 \\
\hline BSML-FTL-7d & $108.65 \pm 19.70$ & 1.30 \\
\hline BBD-FLK-1I & $108.07 \pm 13.09$ & 0.84 \\
\hline BBD-FLK-1c & $101.00 \pm 6.31$ & 0.79 \\
\hline BBD-216-4e & $99.69 \pm 8.49$ & 0.96 \\
\hline BSML-FTL-7o & $97.87 \pm 5.70$ & 0.98 \\
\hline BBD-FTL-6p & $95.79 \pm 8.34$ & 0.92 \\
\hline BSML-FTL-6u & $95.24 \pm 7.32$ & 1.14 \\
\hline BBD-FTL-6n & $90.13 \pm 11.79$ & 0.87 \\
\hline BSML-FLK-10 & $86.97 \pm 6.15$ & 0.87 \\
\hline BSML-FLK-1n & $83.78 \pm 5.23$ & 0.84 \\
\hline BBD-216-3d & $83.11 \pm 1.18$ & 0.80 \\
\hline BSML-FLK-1b & $82.63 \pm 13.75$ & 0.82 \\
\hline BBD-FTL-1f & $79.15 \pm 19.45$ & 0.95 \\
\hline BBD-217-2b & $74.40 \pm 18.98$ & 0.89 \\
\hline BSML-FTL-6r & $74.10 \pm 6.47$ & 0.89 \\
\hline BSML-FLK-1d & $73.34 \pm 3.42$ & 0.73 \\
\hline BSML-FTL-7n & $71.46 \pm 14.37$ & 0.71 \\
\hline BBD-FTL-6o & $66.86 \pm 5.12$ & 0.64 \\
\hline BBD-FTL-1b & $65.54 \pm 2.36$ & 0.63 \\
\hline & & \\
\hline
\end{tabular}

\begin{tabular}{|c|c|c|}
\hline Isolate CF & $\begin{array}{c}\% \text { Al-2 Activity } \\
( \pm \text { SD) }\end{array}$ & $\begin{array}{l}\text { Induction of } \\
\text { Luminescenne }\end{array}$ \\
\hline BSML-FLK-1h & $65.31 \pm 6.42$ & 0.65 \\
\hline BSML-FLK-1a & $65.15 \pm 2.62$ & 0.65 \\
\hline BSML-FLK-1I & $63.28 \pm 2.79$ & 0.63 \\
\hline BSML-FTL-8b & $60.89 \pm 10.03$ & 0.61 \\
\hline BBD-FTL-5f & $60.07 \pm 11.62$ & 0.58 \\
\hline BSML-FLK-1m & $59.76 \pm 9.66$ & 0.60 \\
\hline BBD-FTL-8c & $57.09 \pm 3.90$ & 0.68 \\
\hline BBD-FTL-7a & $55.74 \pm 4.52$ & 0.54 \\
\hline BBD-FTL-4b & $54.91 \pm 5.43$ & 0.43 \\
\hline BBD-FTL-6k & $51.74 \pm 2.51$ & 0.50 \\
\hline BBD-FLK-1j & $49.43 \pm 9.76$ & 0.39 \\
\hline BSML-FTL-6w & $48.67 \pm 6.20$ & 0.47 \\
\hline BBD-217-2d & $47.87 \pm 6.88$ & 0.46 \\
\hline BBD-FLK-1e & $45.18 \pm 1.91$ & 0.44 \\
\hline BBD-216-4a & $42.64 \pm 4.45$ & 0.51 \\
\hline BBD-FTL-1m & $42.12 \pm 0.30$ & 0.50 \\
\hline HSML-FTL-10r & $39.91 \pm 4.77$ & 0.32 \\
\hline BBD-FTL-7b & $39.29 \pm 1.19$ & 0.38 \\
\hline BBD-FTL-3h & $37.65 \pm 2.27$ & 0.36 \\
\hline BBD-FTL-1h & $37.16 \pm 6.77$ & 0.44 \\
\hline HSML-FTL-11I & $36.33 \pm 5.64$ & 0.37 \\
\hline BBD-FTL-1e & $35.45 \pm 2.36$ & 0.42 \\
\hline BSML-FLK-1f & $35.18 \pm 8.99$ & 0.35 \\
\hline HSML-FTL-9i & $33.60 \pm 3.87$ & 0.27 \\
\hline BBD-FTL-6q & $32.48 \pm 1.54$ & 0.31 \\
\hline HSML-FTL-9c & $31.19 \pm 5.50$ & 0.25 \\
\hline BBD-FTL-6I & $30.55 \pm 2.75$ & 0.29 \\
\hline BBD-FTL-6h & $28.24 \pm$ & 0.22 \\
\hline
\end{tabular}


Table 12. Results of the Al-2 assay using the Vibrio harveyi BB170 reporter strain presented according to isolate type.

\begin{tabular}{|l|r|r|r|}
\hline \multicolumn{1}{|c|}{ Isolate Type } & No. CFs Tested & $\begin{array}{c}\text { No. CFs with Positive Al-2 } \\
\text { Assay Result }\end{array}$ & $\begin{array}{c}\text { Percentage of Positive Al-2 } \\
\text { Assay Results (\% of total) }\end{array}$ \\
\hline BBD & 63 & 44 & $52 \%(70 \%)$ \\
\hline BSML & 37 & 25 & $30 \%(68 \%)$ \\
\hline HSML & 45 & 15 & $18 \%(33 \%)$ \\
\hline Cyanobacteria & 8 & 0 & $0 \%(0 \%)$ \\
\hline Totals & 153 & 84 & $100 \%(\mathrm{n} / \mathrm{a})$ \\
\hline
\end{tabular}

Some of the components of growth media, such as borate (Burgess et al. 2002, DeKeersmaecker and Vanderleyden 2003) and glucose (Chen et al. 2002), can induce luminescence in the Vibrio harveyi BB170 reporter strain. This was controlled here in the Al-2 assay by including medium control wells. None of the media used in this study stimulated light production in the Al-2 assay prior to self-induction by the $V$. harveyi BB170 reporter strain (Figure 5). The media reference wells (containing $100 \mu$ l of the relevant growth media) were also monitored during the Al-2 assays to determine background luminescence output for each of the media tested. The slight rise in luminescence near the end of the experiment could likely be a result of light contamination from adjacent wells; none of the tested growth media caused an increase in light production over the course of the Al-2 assay (Figure 5).

Eight CFs appeared to affect the Al-2 assay, either by impacting growth and/or light production of the $V$. harveyi BB170 reporter strain. Table 13 provides a summary of the observed impacts for these eight CFs. The CFs obtained from six isolates (BBD-FTL-5d, HSML-FTL-10a, HSML-FTL-10c, HSML-FTL-10f, HSML-FTL-10q, and HSML-FTL-11e) inhibited the growth and luminescence of $V$. harveyi BB170 during the assay (Figure 6). The CF obtained from BSMLFTL-7a inhibited growth of $V$. harveyi BB170 but did not inhibit luminescence (Figure 7). The CF obtained from BSML-FTL-7j inhibited luminescence of $V$. harveyi BB170 without impacting its growth (Figure 8). 


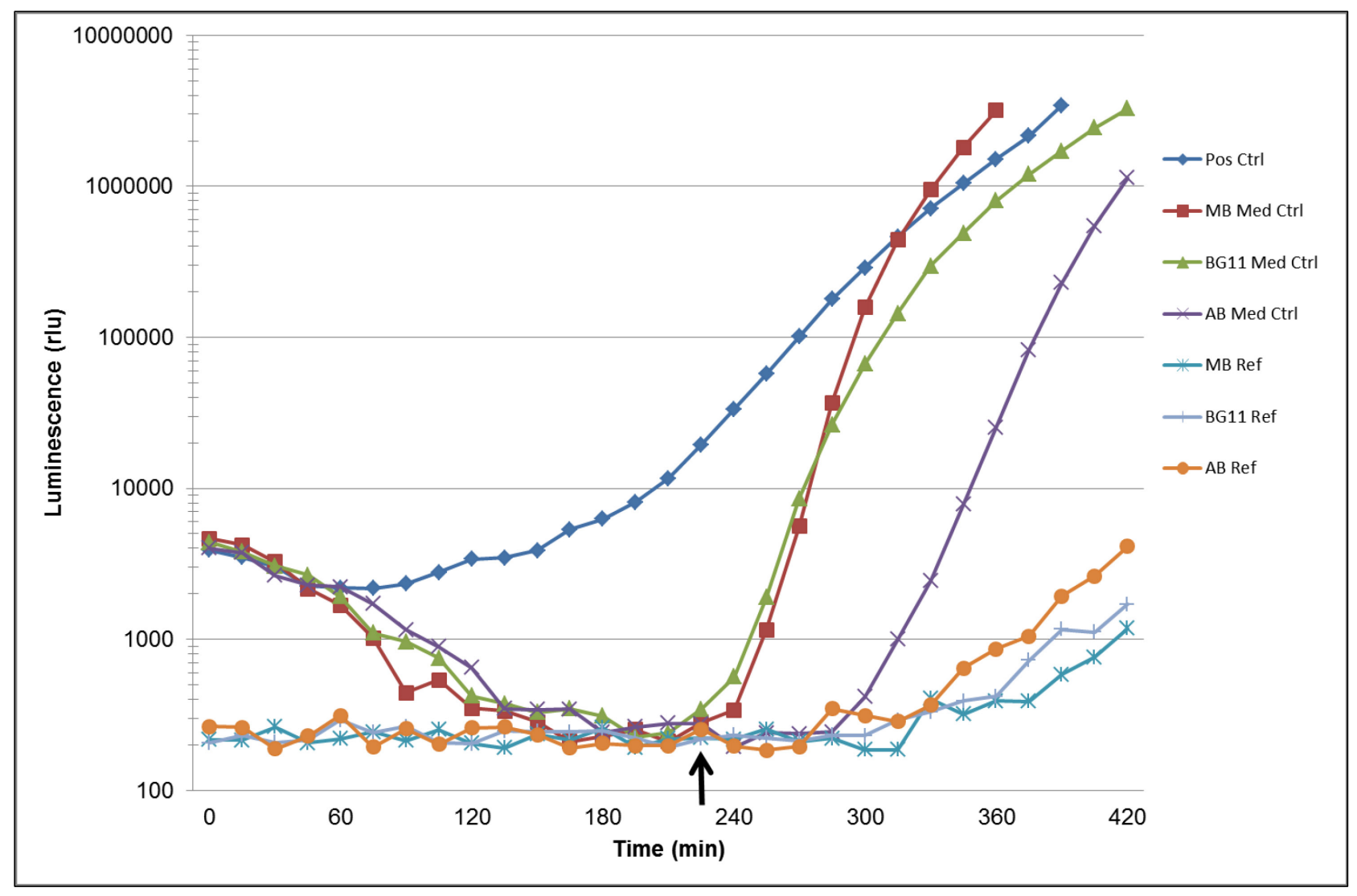

Figure 5. Light production of the media control wells and media reference wells in the Al-2 assay. The medium control curves indicate that the three growth media used in this study did not stimulate light production prior to self-induction by the Vibrio harveyi BB170 reporter strain. The luminescence of the medium reference wells, which contained sterile growth media, remained minimal over the course of the Al-2 assay, although some minor increases in light were measured in these wells at the end of the assay due to light contamination from adjacent wells. Time of self-induction by the reporter strain is indicated by arrow. Table 5 shows contents of each well type in the Al-2 assay. 
Table 13. Effect of exposure of the Vibrio harveyi BB170 reporter strain to culture filtrates of various isolates during the Al-2 assay. included inhibition of growth and/or light production.

\begin{tabular}{|l|c|c|}
\hline Isolate Name & Effect on $\boldsymbol{V}$. harveyi BB170 Growth & $\begin{array}{c}\text { Effect on } \boldsymbol{V} \text {. harveyi BB170 Light } \\
\text { Production }\end{array}$ \\
\hline BBD-FTL-5d & Inhibited & Inhibited \\
\hline BSML-FTL-7a & Inhibited & None \\
\hline BSML-FTL-7j & None & Inhibited \\
\hline HSML-FTL-10a & Inhibited & Inhibited \\
\hline HSML-FTL-10c & Inhibited & Inhibited \\
\hline HSML-FTL-10f & Inhibited & Inhibited \\
\hline HSML-FTL-10q & Inhibited & Inhibited \\
\hline HSML-FTL-11e & Inhibited & Inhibited \\
\hline
\end{tabular}



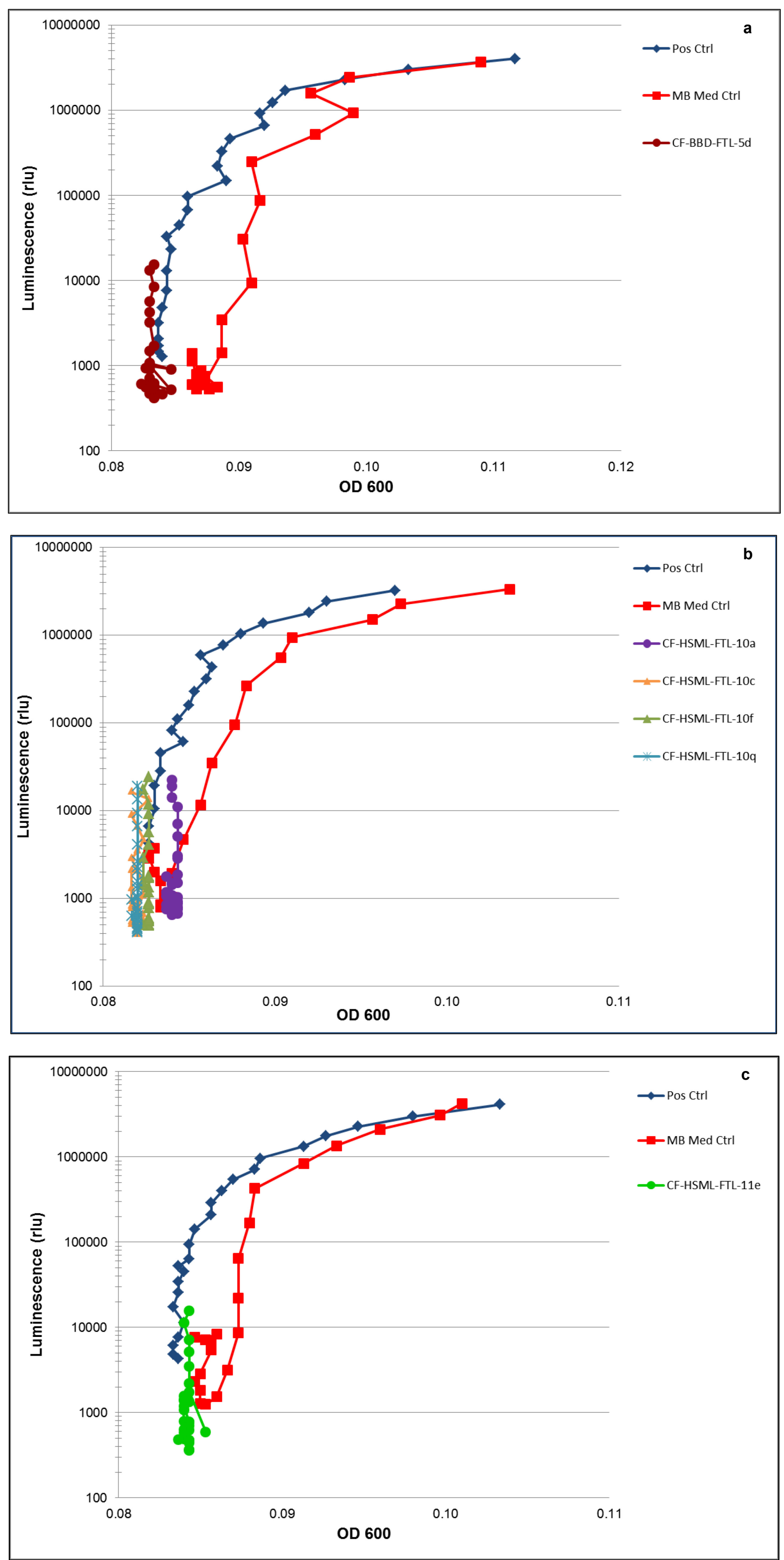

Figure 6. Light production versus optical density at $600 \mathrm{~nm}$ in the Al-2 assay. Presence of the CFs from six isolates inhibited both growth and luminescence of the Vibrio harveyi BB170 reporter strain; (a) BBD-FTL-5d; (b) HSML-FTL-10a, HSML-FTL-10c, HSML-FTL-10f, and HSMLFTL-10q; (c) HSML-FTL-11e. 


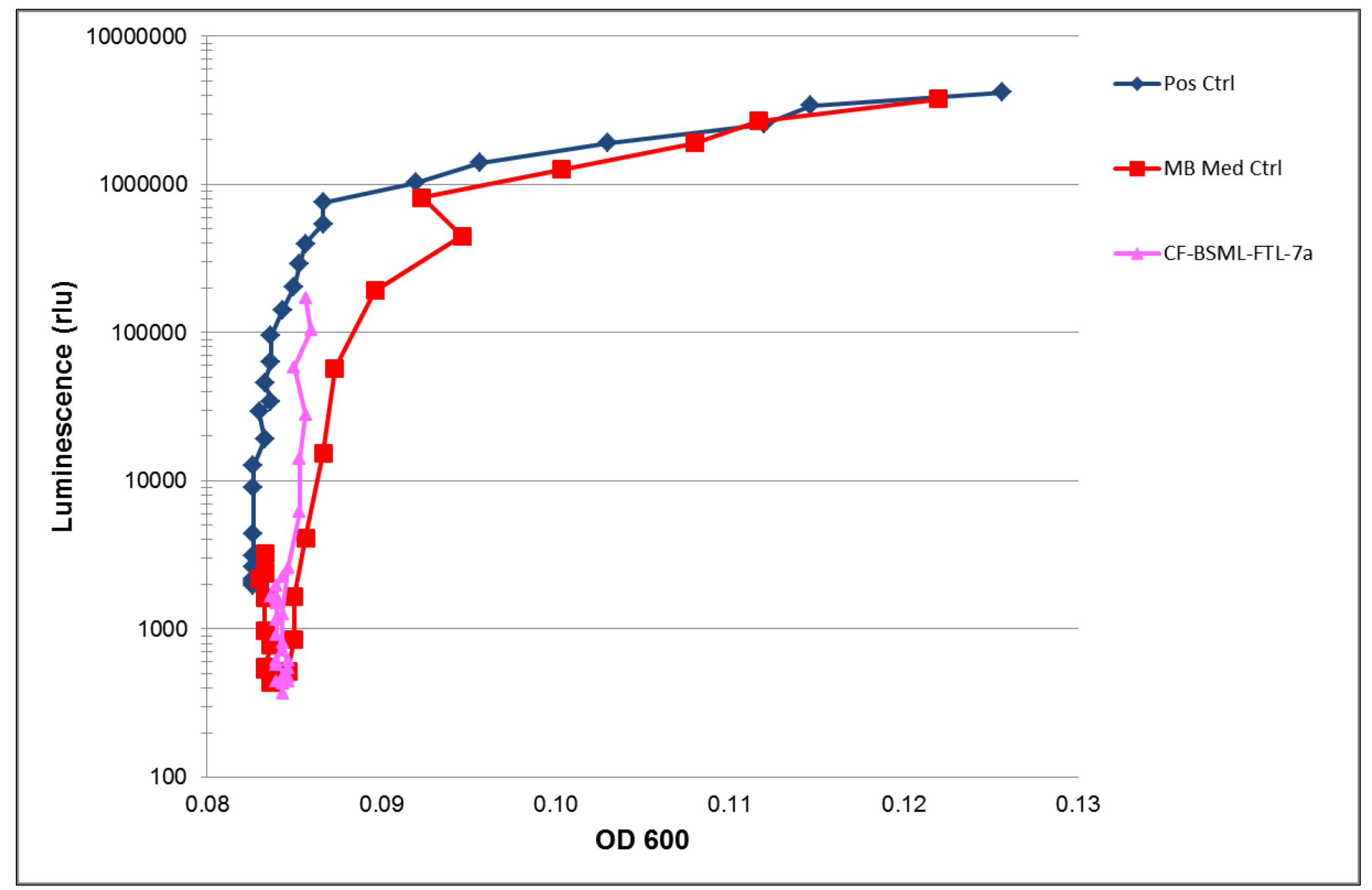

Figure 7. Light production versus optical density at $600 \mathrm{~nm}$ in the Al-2 assay. Presence of the CF from BSML-FTL-7a inhibited growth of the Vibrio harveyi BB170 reporter strain but did not inhibit luminescence. 


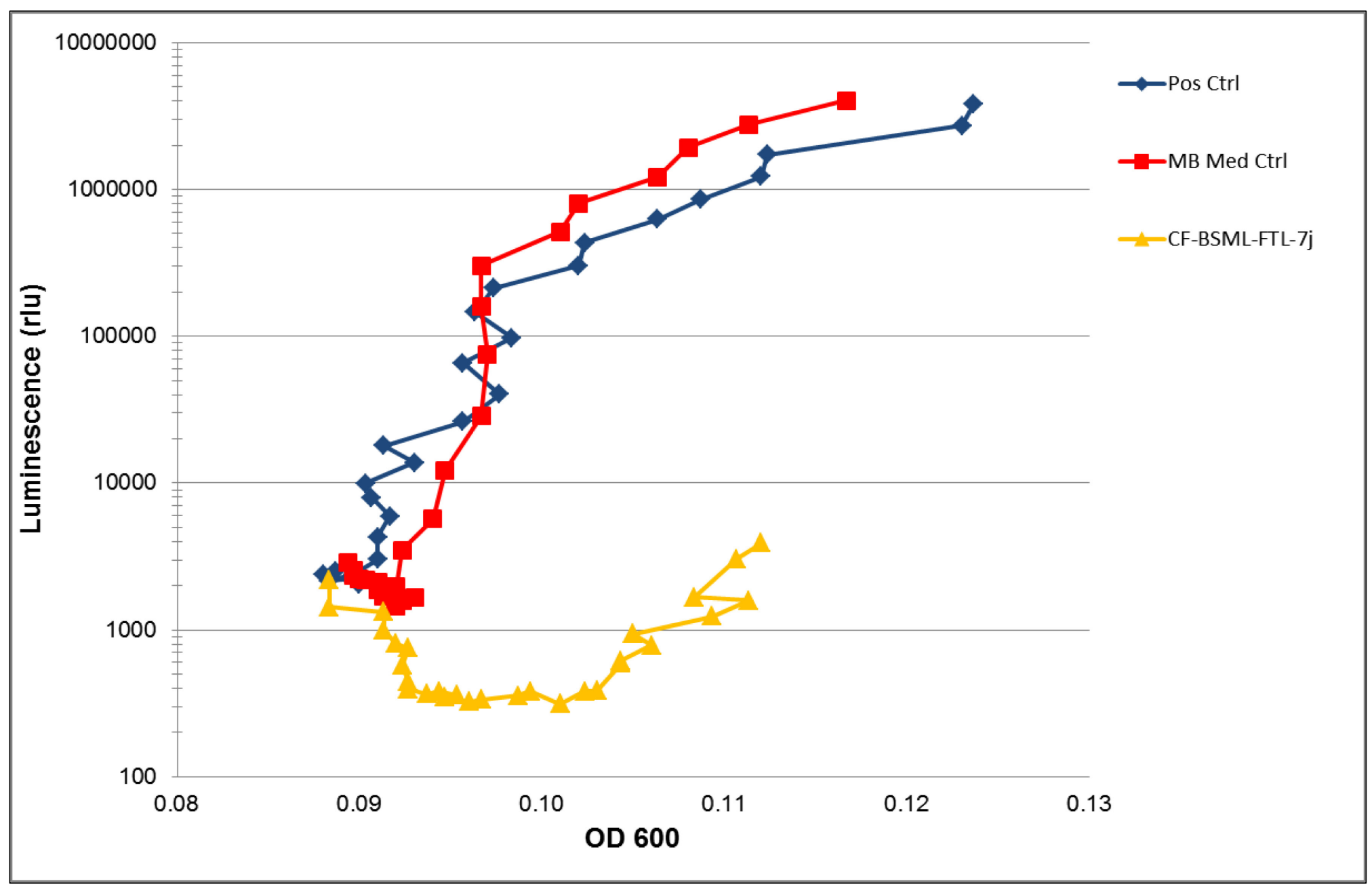

Figure 8. Light production versus optical density at $600 \mathrm{~nm}$ in the Al-2 assay. Presence of the CF from BSML-FTL-7j inhibited luminescence without affecting growth of the Vibrio harveyi BB170 reporter strain. 


\section{Bacterial Growth Challenges}

Nineteen isolate CFs were examined in the bacterial growth challenges, including nine isolate CFs that tested positive for $\mathrm{AHL}$ production in this study and 10 isolates that tested negative for QS with all three quorum sensing reporter strains used in this study. Of the 19 isolate CFs tested, eight were CFs from BBD isolates, six were CFs of isolates from the SML of BBD-infected corals, and five were CFs of isolates from the SML of apparently healthy corals. The bacterial growth challenges were conducted in an effort to examine the effects (i.e., stimulation/inhibition) of the CFs on isolate growth. For each culture, the mean growth rate constant $(\mu)$ and mean generation time $(g)$ were calculated for the untreated control culture as well as the experimental treatments (exposure of the culture to the CFs of the 18 other isolates). To determine whether the mean growth rates for each of the CF challenges were significantly different from the mean growth rate of the control culture, independent t-tests were performed. Only statistically significant effects on culture growth will be discussed (t-test, $p<0.05$ ).

A total of 342 growth challenges were conducted. The mean growth rate constant and generation time for all 19 isolates examined are presented in the Appendix. Of these, $92 \mathrm{CF}$ challenges $(\sim 27 \%)$ resulted in a significant inhibition of isolate growth. Each of the $19 \mathrm{CFs}$ examined inhibited two or more of the tested isolate cultures. The CFs from HSML-FTL-10a and BSML-FTL-7I inhibited the greatest numbers of isolates (11 and nine isolate cultures, respectively). The isolates that experienced growth inhibition by the greatest number of CFs included BBD-FTL-8c (inhibited by $16 \mathrm{CFs}$ ), HSML-FTL-10a (inhibited by $14 \mathrm{CFs}$ ), and BSMLFTL-7q (inhibited by 12 CFs). Three isolates (HSML-FTL-9i, BSML-FTL-6u, and BSML-FLK-1d) were neither inhibited nor stimulated by exposure to any of the CFs tested. Eight of the 342 growth challenges $(\sim 2 \%)$ resulted in significant stimulation of isolate growth. Growth in only three of the 19 cultures examined was stimulated by exposure to one or more CFs. Two cultures (BBD-FTL-1h and BBD-FTL-6n) accounted for seven of the eight observed stimulatory growth effects, with the third culture (HSML-FTL-9e) only being stimulated by a single CF. 
The CFs of isolates from healthy corals inhibited growth in the greatest percentage of challenges $(\sim 32 \%)$, followed by the CFs of isolates from the SML of BBD-infected corals $(\sim 26 \%)$, and CFs of BBD isolates ( 24\%; Table 14). Growth stimulation occurred in approximately $4 \%$ of challenges with CFs of isolates from the SML of BBD-infected corals, $2 \%$ of challenges with CFs of isolates from BBD, and $1 \%$ of challenges with CFs of isolates from the SML of healthy corals. Independent group t-tests revealed that there was no significant difference $(p>0.05)$ between the numbers of cultures inhibited or stimulated by CFs from any combination of the three isolate types.

Of the 342 challenges conducted, 162 were conducted with CFs of AHL-producing isolates and 180 were conducted with the CFs of non-QS isolates. As shown in Table 15, the CFs of AHL-producing isolates inhibited growth in a slightly greater percentage of cultures $(\sim 28 \%)$ than the CFs of non-QS isolates ( 26\%); however, no statistically significant difference was detected between the two isolate types. The two CFs that inhibited the greatest number of cultures (HSML-FTL-10a and BSML-FTL-7I) are both AHL-producing isolates. Growth stimulation was more frequently observed with challenges using CFs from non-QS isolates ( $4 \%$ of challenges) than with the CFs of AHL-producing isolates ( $1 \%$ of challenges), which only stimulated growth in a single challenge. There was a statistically significant difference observed between the number of cultures stimulated by CFs of $Q S$ isolates $(M=0.11, S D=0.33)$ and nonQS isolates $(M=0.70, S D=0.67) ; t(17)=2.1, p<0.05$. 
Table 14. The number and percentage of isolate cultures that showed inhibition and stimulation of growth when challenged with the culture filtrates (CFs) of isolates from BBD, CFs of isolates from the SML of BBD-infected corals, and CFs of isolates from the SML of apparently healthy corals.

\begin{tabular}{|c|c|c|c|}
\hline Isolate Source & CF Tested & $\begin{array}{l}\text { No. Cultures } \\
\text { Inhibited by CF }\end{array}$ & $\begin{array}{c}\text { No. Cultures } \\
\text { Stimulated by CF }\end{array}$ \\
\hline \multirow{10}{*}{$\begin{array}{c}\text { BBD Mat } \\
\text { (144 challenges) }\end{array}$} & BBD-FTL-6j & 6 & 0 \\
\hline & BBD-FTL-8c & 3 & 0 \\
\hline & BBD-FLK-1d & 3 & 0 \\
\hline & BBD-FTL-1h & 4 & 0 \\
\hline & BBD-FTL-6d & 6 & 1 \\
\hline & BBD-FTL-6n & 5 & 0 \\
\hline & BBD-FTL-6p & 6 & 1 \\
\hline & BBD-FLK-1e & 2 & 1 \\
\hline & Total No. & 35 & 3 \\
\hline & $\%$ Impacted & $24 \%$ & $2.1 \%$ \\
\hline \multirow{8}{*}{$\begin{array}{l}\text { SML from BBD- } \\
\text { Infected Coral } \\
\text { (108 challenges) }\end{array}$} & DCMM $5 T 16$ & & \\
\hline & $\begin{array}{l}\text { BSIML-FIL-6W } \\
\text { BSML-FTL-7L }\end{array}$ & $\begin{array}{l}3 \\
9\end{array}$ & $\begin{array}{l}1 \\
0\end{array}$ \\
\hline & BSML-FTL-6u & 3 & 1 \\
\hline & BSML-FTL-7d & 5 & 2 \\
\hline & BSML-FTL-7q & 4 & 0 \\
\hline & BSML-FLK-1d & 4 & 0 \\
\hline & Total No. & 28 & 4 \\
\hline & $\%$ Impacted & $26 \%$ & $3.7 \%$ \\
\hline & & & \\
\hline \multirow{7}{*}{$\begin{array}{c}\text { SML from Healthy } \\
\text { Coral } \\
\text { (90 challenges) }\end{array}$} & HSML-FTL-9c & 3 & 0 \\
\hline & HSML-FTL-9e & 4 & 0 \\
\hline & HSML-FTL-9i & 4 & 0 \\
\hline & HSML-FTL-10a & 11 & 0 \\
\hline & HSML-FTL-10r & 7 & 1 \\
\hline & Total No. & 29 & 1 \\
\hline & $\%$ Impacted & $32 \%$ & $1.1 \%$ \\
\hline
\end{tabular}


Table 15. The number and percentage of isolate cultures that showed inhibition and stimulation of growth when challenged with the culture filtrates (CFs) of isolates from AHL-producing isolates and non-QS isolates.

\begin{tabular}{|c|c|c|c|}
\hline Quorum Sensing & CF Tested & $\begin{array}{l}\text { No. Cultures } \\
\text { Inhibited by CF }\end{array}$ & $\begin{array}{c}\text { No. Cultures } \\
\text { Stimulated by CF }\end{array}$ \\
\hline \multirow{11}{*}{$\begin{array}{l}\text { AHL-Producing } \\
\text { Isolates }\end{array}$} & BBD-FTL-6j & 6 & 0 \\
\hline & BBD-FTL-8c & 3 & 0 \\
\hline & BBD-FLK-1d & 3 & 0 \\
\hline & BSML-FTL-6w & 3 & 1 \\
\hline & BSML-FTL-7L & 9 & 0 \\
\hline & HSML-FTL-9c & 3 & 0 \\
\hline & HSML-FTL-9e & 4 & 0 \\
\hline & HSML-FTL-9i & 4 & 0 \\
\hline & HSML-FTL-10a & 11 & 0 \\
\hline & Total No. & 46 & 1 \\
\hline & $\%$ Impacted & $28 \%$ & $0.62 \%$ \\
\hline \multirow{12}{*}{ Non-QS Isolates } & BBD-FTL-1h & 4 & 0 \\
\hline & BBD-FTL-6d & 6 & 1 \\
\hline & BBD-FTL-6n & 5 & 0 \\
\hline & BBD-FTL-6p & 6 & 1 \\
\hline & BBD-FLK-1e & 2 & 1 \\
\hline & BSML-FTL-6u & 3 & 1 \\
\hline & BSML-FTL-7d & 5 & 2 \\
\hline & BSML-FTL-7q & 4 & 0 \\
\hline & BSML-FLK-1d & 4 & 0 \\
\hline & HSML-FTL-10r & 7 & 1 \\
\hline & Total No. & 46 & 7 \\
\hline & $\%$ Impacted & $26 \%$ & $3.9 \%$ \\
\hline
\end{tabular}




\section{CONCLUSIONS AND DISCUSSION}

\section{Quorum Sensing in BBD and Coral-Associated Bacteria}

The findings of this study demonstrate that AHLs are present within the BBD microbial mat, as indicated by the positive reaction of BBD mat samples in the AHL assays. Thus, the BBD microbial constituents are producing AHLs in situ. Quorum sensing signals have previously been documented in cyanobacterial colonies and cyanobacterial-dominated microbial mats in varied environments. Trichodesmium colonies in the North Atlantic produce both AHLs and AI-2 (Van Mooy et al. 2012). An array of AHL molecules have been documented from environmental samples of cyanobacterial-dominated microbial mats, including marine stromatolites in the Bahamas (Decho et al. 2009) and cyanobacterial mats in Swiss alpine wetland ponds (Bachofen and Schenk 1998). While AHLs are known to control virulence factors in the coral pathogen Serratia marcescens (Van Houdt et al. 2007), this is the first study to document the presence of QS signals within active coral disease. None of the eight BBD cyanobacterial isolates examined in this study were found to produce a positive result in the AHL assays; however, it should be noted that the cyanobacterial culture medium has a $\mathrm{pH}$ of $\sim 8$ (or higher during photosynthesis) and alkaline $\mathrm{pH}$ has been demonstrated to degrade AHL signals (Byers et al. 2002, Yates et al. 2002).

This study also demonstrates that individual members of the BBD mat and of the microbial communities within the SML of healthy and BBD-infected corals are capable of producing QS signals. Nine of the 153 isolates ( 6\%) examined in this study were found to produce AHLs (i.e., C4-C14 AHLs recognized by the Chromobacterium violaceum CV026 and Agrobacterium tumefaciens NTL4(pZLR4) reporter strains). This is similar to the $4 \%$ observed by Alagely et al. (2011), who screened more than 300 bacterial cultures isolated from marine invertebrates (i.e., coral SML, other marine invertebrates, and dinoflagellate symbionts) using a variety of reporter strains that detect AHLs of varied chain lengths. Various coral-associated Vibrio spp. have also been documented to produce AHLs (Tait et al. 2010). 
More than half ( $\sim 55 \%)$ of the $153 \mathrm{CFs}$ investigated in this study produced a positive result in the Al-2 assay, indicating that these CFs contain Al-2-like molecules (or the CAI-1 signal specific to some Vibrio spp.) which can be detected by the Vibrio harveyi BB170 reporter strain. The high percentage of isolates producing $\mathrm{Al}-2$ is not unexpected, as $\mathrm{Al}-2$ is hypothesized to be an interspecies signal molecule (Surette et al. 1999; Xavier and Bassler 2003). Because detection of $\mathrm{Al}-2$ is possible by both the producing bacteria, as well as by neighboring bacteria with an $\mathrm{Al}-2$ receptor, $\mathrm{Al}-2$ has been called the "universal signaling molecule" (Bandara et al. 2012, Jayaraman and Wood 2008).

Considering that 88 of the $153(\sim 58 \%)$ bacterial isolates examined in this study were shown to produce AHLs and/or Al-2, it is highly likely that some or all of these isolates could be producing QS signals in situ. However, it is important to clarify that the results of the QS screening assays for the isolate CFs should be tempered by the fact that they assessed signal production under very specific conditions in a laboratory environment in which the planktonic cell form predominates. In the natural environment, it is possible that these strains may not reach threshold densities and are likely in the biofilm environment on the coral surface. The QS signals might also be inhibited or inactivated by chemical conditions or QS antagonists. Furthermore, the QS signal production may not occur under the physical and chemical microenvironments available in the host coral. As the vast majority of bacteria ( $99 \%)$ cannot be grown in pure culture due to difficulties associated with producing specific micro-environmental requirements in the laboratory (Fuhrman and Campbell 1998), unculturable bacteria may also be producing the AHLs detected in the BBD mat samples. Additionally, the absence of a positive reaction in the reporter strain assays might result from a variety of possible scenarios: (1) the bacterial isolate synthesized a QS signal that was undetectable by the microbial reporter strains used in this study; (2) the bacterial isolate was capable of producing a QS signal, but it did not synthesize the signal at detectable levels under the culture conditions of this study; (3) the isolate produced a chemical entity that inhibits the growth of the reporter strain or its ability to produce a positive result (quorum quenching); (4) the bacterial isolate did not produce QS signals during the part of 
the growth curve examined in this study (early stationary phase); and (5) abiotic factors (e.g., temperature, $\mathrm{pH}$, etc.) caused degradation of the QS signals that were produced.

Near full-length 16S rRNA gene sequences of the nine AHL-producing isolates were examined for taxonomic information. Based upon the results of the BLAST search, all nine AHLproducing isolates are members of the Alpha- and Gamma-proteobacteria. Three of the nine isolates were closely related to species of Vibrio. Two isolates from BBD (i.e., BBD-FTL-6j and BBD-FTL-8c) were most closely related ( $99 \%$ similarity) to a strain of $V$. rotiferianus isolated from rotifers collected in Belgium (Gomez-Gil et al. 2003). It should be noted that, although BBD-FTL6j and BBD-FTL-8c shared the same closest relative in GenBank, these two isolates showed differing morphologies and were isolated from two different BBD samples on two separate coral colonies. Isolate HSML-FTL-9c was closely related (99\% similarity) to a strain of $V$. harveyi (strain 1280 from the NCIMB culture collection) isolated from a dead amphipod at Woods Hole, Massachusetts, USA (Johnson and Shunk 1936). Vibrio harveyi represents one of the archetypal systems of AHL-regulated gene expression (Bassler et al. 1993) and a variety of Vibrio spp. have been documented to produce AHLs, including V. fischeri, V. parahaemolyticus, V. anguillarum, and V. rotiferianus (Bassler 1999, Buch et al. 2003, Henke and Bassler 2004b, García-Aljaro et al. 2012). Members of the Vibrio genus have previously been documented to occur within BBD (Barneah et al. 2007, Sekar et al. 2008, Arotsker et al. 2009) and it has recently been suggested that proteolytic activity by Vibrio spp. might play a role in BBD pathology (Arotsker et al. 2009). In addition, Vibrio strains isolated from both healthy and diseased corals have been shown to produce AHLs (Tait et al. 2010).

Two AHL-producing isolates (i.e., BBD-FLK-1d and BSML-FTL-6w) were most closely related to bacteria isolated from a marine electroactive biofilm in the port of Genoa, Italy. The closest relative for BBD-FLK-1d was Nautella italica strain LMG 24365 (Vandecandelaere et al. 2009; $99 \%$ similar) and the closest relative for BSML-FTL-6w was Ruegeria scottomollicae LMG 24367 (Vandecandelaere et al. 2008; 96\% similar). Because BSML-FTL-6w and $R$. scottomollicae share less than $97 \%$ similarity, they do not represent the same species 
(Stackebrandt and Goebel 1994). Both N. italica and R. scottomollicae belong to the Rhodobacteraceae, which is represented in BBD and in coral SML (Sekar et al. 2006, 2008). AHL production by members of the Roseobacter-Ruegeria subgroup of the Alpha-proteobacteria has been previously demonstrated (Gram et al. 2002, Taylor et al. 2004, Case et al. 2011). Isolates BSML-FTL-7I and HSML-FTL-10a were most closely related to strains from the genus Pseudoalteromonas and members of this genus have previously been documented to produce AHLs (Huang et al. 2008, 2009). Isolate BSML-FTL-7I shared 98\% 16S rRNA gene identity with $P$. phenolica strain O-BC30, which was isolated from seawater collected near Tokyo, Japan (Isnansetyo and Kamei 2003). Isolate HSML-FTL-10a was most closely related to $P$. luteoviolacea strain NCIMB 1893 (99\% similarity), which was isolated from seawater in the Mediterranean Sea near Nice, France (Gauthier 1976). Consistent with the description of $P$. luteoviolacea as a producer of violacein (Gauthier 1982), isolate HSML-FTL-10a produced a dark purple pigment. Considering that $P$. luteoviolacea has been documented to have antibacterial activity (Gauthier 1982) and antibiotic activity has also been demonstrated for violacein (Lichstein and Van De Sand 1946), it is not unexpected that the CF from HSML-FTL-10a inhibited growth in the greatest number of isolates during the bacterial growth challenges in this study. Furthermore, multiple studies have shown that species of Pseudoalteromonas isolated from coral SML show antibiotic activity (Ritchie 2006, Nissimov et al. 2009, Shnit-Orland et al. 2009).

Isolates HSML-FTL-9e and HSML-FTL-9i did not have highly similar homolog sequences present in the BLAST database. Isolate HSML-FTL-9e was distantly related ( $95 \%$ similarity) to Aliagarivorans marinus strain AAM1, isolated from coastal seawater off Taiwan (Jean et al. 2009). Isolate HSML-FTL-9i was most closely related (96\% similarity) to Pseudoruegeria aquimaris strain SW-255, isolated from coastal seawater in the East Sea, Korea (Yoon et al. 2007).

Three strains of bacteria that were previously isolated from BBD (BBD-216-2d, BBD-2161b, BBD-217-2d) tested positive for Al-2 production. The closest taxonomic relative of these three isolates was identified as Vibrio harveyi, which possesses a well-characterized LusS/LuxPQ Al-2 QS system (Bassler et al. 1994, Surette et al. 1999). It is interesting to note that, despite the 
well-characterized AHL QS system in V. harveyi, these three strains did not test positive in the AHL assays. Culture filtrates from two isolates of Bacillus (BBD-216-3d and BBD-216-4e) activated the Al-2 reporter strain. Members of the genus Bacillus have previously been shown to produce Al-2 (Jones and Blaser 2003, Auger et al. 2006). No existing studies showing production of Al-2 by Loktanella sp. (BBD-216-4a) or Kocuria sp. (BBD-217-2b) were identified.

\section{Potential Fate of AHLs in the BBD Mat and Coral SML}

Bacterial constituents of the BBD mat and the coral SML are living within complex environments where abiotic factors (e.g., $\mathrm{pH}$, temperature, chemical composition of the environment) and biotic factors (e.g., presence of other members of the bacterial community) are in constant flux. Such fluctuations can affect the generation, movement, and reception of QS signals (Boyer and Wisniewski-Dye 2009). Production of AHLs may be specific to a certain portion of the bacterial growth phase and may be specific to the particular strain (Tait et al. 2005). Additionally, production of both the $\mathrm{AHL}$ and $\mathrm{Al}-2$ signals may be influenced by the growth medium (Burgess et al. 2002, DeKeersmaecker and Vanderleyden 2003, Boyer and WisniewskiDyé 2009). Thus, signal production may be affected by the chemical substrates in the environment that are available for growth and by the physical environments available for colonization. In this study, four bacterial isolates tested positive in the AHL assays when surface cultures (patch tests) were examined, but tested negative for AHLs when broth cultures (CF assays) were examined in the same assay (Table 7). These conflicting results could be attributed to the differing growth conditions (surface growth as a biofilm on agar vs. suspended cells as planktonic forms in liquid medium). To the author's knowledge, variation in AHL production associated with these conditions has not been previously documented in the literature. An alternative explanation would be that no AHLs are present in the stationary phase of the growth cycle for these particular isolates.

The effective signaling distance between cells (the 'calling distance') is limited to short distances (i.e., tens of micrometers; Decho et al. 2010). In aqueous solutions, smaller molecules (e.g., short-chain AHLs) would diffuse more rapidly than larger molecules (e.g., long-chain AHLs). 
Within the BBD mat, an exopolysaccharide (EPS) matrix surrounds the microbial constituents as a biofilm. High concentrations (>600 $\mu \mathrm{M})$ of AHLs have been measured within Pseudomonas aeruginosa biofilms (Charlton et al. 2000), suggesting that bacterial EPS may effectively sequester QS signals. The size of the signal molecules and size of the water channels within the EPS matrix (Donlan and Costerson 2002) would dictate the diffusion characteristics of larger molecules (e.g., long-chain AHLs; Decho et al. 2010). Because the surface of the BBD mat is exposed to seawater, and thus advection and dilution (Horswill et al. 2007), accumulation of QS signals would likely be greater in the depths of the BBD mat than on the mat surface. Coral mucus forms a protective coating over the coral surface. Although the chemical composition of coral mucus varies between species (Meikle et al. 1988), the basic structure of the SML consists of an insoluble, hydrated glycoprotein (Ducklow and Mitchell 1979; Meikle et al. 1988). In similar fashion to the EPS in microbial mats, the gel-like nature of coral mucus would likely concentrate particularly hydrophobic signal molecules.

Once the QS signal has left the cell, its success in conferring information is dependent upon its the ability to persist in the natural environment and eventually reach a receptor cell. Quorum sensing signals may be impacted by the local chemical and physical microenvironment. For instance, alkaline conditions have been demonstrated to result in hydrolysis of the AHL lactone ring (Byers et al. 2002, Yates et al. 2002). It should be noted, however, that the hydrolyzed lactone ring is capable of spontaneous re-lactonization once the $\mathrm{pH}$ is lowered (Horswill et al. 2007). This hydrolysis appears to be dependent upon the acyl chain length, as short-chain (<C10) AHLs appear to be more susceptible (Decho et al. 2009, Yates et al. 2002). The alkaline $\mathrm{pH}$ conditions within the BBD mat could contribute to AHL hydrolysis during daylight. Decho et al. (2009) monitored the in situ degradation of short-chain AHLs within cyanobacterial mats by measuring the concentrations of extractable AHLs collected from daytime and nighttime samples. In darkness, the lowered $\mathrm{pH}$ conditions might confer greater stability to $\mathrm{AHL}$ molecules (Decho et al. 2009). Decho et al. $(2009,2010)$ suggest that microbial mats may potentially use shorter-chain AHL signaling during the nighttime conditions and longer-chain AHLs during the 
daytime. The lower $\mathrm{pH}$ conditions occurring at night would allow for effective signaling using both short and long chain AHLs.

The BBD mat contains pronounced biogeochemical microgradients in oxygen, $\mathrm{pH}$, and sulfide (Carlton and Richardson 1995, Glas et al. 2012). In BBD, strong diel fluctuations in oxygen and $\mathrm{pH}$ occur in association with changes in the predominant metabolic pathways within the mat. During daylight, sulfide-resistant oxygenic photosynthesis by BBD cyanobacteria is the dominant metabolic pathway (Myers and Richardson 2009), creating oxic conditions in the majority of the mat (Carlton and Richardson 1995). In daylight, $\mathrm{CO}_{2}$ is removed from the mat more quickly than it is replenished and the $\mathrm{pH}$ within the mat rises. During daylight, the $\mathrm{pH}$ in the BBD mat ranges from $7.58-8.13$ (Glas et al. 2012). During darkness, as the oxygen is used up in aerobic respiration and the base of the mat becomes anoxic, the predominant metabolic pathway shifts to heterotrophic respiration and fermentation (Richardson and Castenholz 1987). The formation of small organic acids during fermentation lowers the $\mathrm{pH}$ within the mat, which has been measured to range from $7.33-7.49$ at the base of the BBD mat during darkness (Glas et al. 2012). It is plausible that the $\mathrm{pH}$ microenvironments in the BBD mat could affect the stability of the $\mathrm{AHL}$ molecules generated within the mat and that diel shifts within the mat could be associated with alterations in signaling. It should be noted, however, that all BBD mat samples collected and analyzed in this study were daytime samples and consistently tested positive for AHL signal presence.

Coral mucus has been demonstrated to be acidic ( $\mathrm{pH}$ of $\sim 7.7$ in Acropora spp. on the Great Barrier Reef, Australia) in comparison to surrounding seawater (Wild et al. 2005). These $\mathrm{pH}$ values could be a result of the chemical nature of the mucus (acid sulfate esters or acid polysaccharides) as well as a result of the respiration and associated $\mathrm{CO}_{2}$ production by the microbes within the SML (reviewed in Wild et al. 2005). Thus, AHL signals within the coral SML would likely remain stable enough for signaling to occur.

Biotic factors, including QS interference (quorum quenching) by other bacteria, can affect the success of QS systems. Quorum quenching can be achieved by suppressing production of 
the QS signal, by affecting diffusion of the signal, or by impacting perception of the signal at a receptor (Bandara et al. 2012). The biological degradation of signaling molecules might be used in antagonistic interactions to prevent QS signals from reaching their intended receptors.

Quorum sensing signals may be internalized and degraded by neighboring bacteria. Some bacteria have been shown to utilize AHLs as a nitrogen or carbon source (Leadbetter and Greenberg 2000, Horswill et al. 2007). Additionally, neighboring bacteria can degrade AHLs using intracellular enzymes, specifically $A H L$ lactonases and $A H L$ acylases (Dong and Zhang 2005). The production of certain compounds (e.g., halogenated furanones, AHL analogs) can inactivate QS signal reception. Both coral-associated bacteria (Tait et al. 2010, Alagely et al. 2011, Bakkiyaraj et al. 2012) and coral mucus (Alagely et al. 2011) have been shown to display quorum quenching activity. Quorum quenching is likely to be occurring in the BBD microbial consortium, as isolates from marine cyanobacteria have been shown to inhibit QS (Gerwick et al. 2012). Also, hot spring microbial mat communities have quorum quenching activity against both $\mathrm{AHL}$ and Al-2 signals (Dobretsov et al. 2011).

\section{Potential Fate of Al-2 in the BBD Mat and Coral SML}

The implications of abiotic and biotic influences on Al-2 signaling are not well understood at this time. Likewise, little is known about the impact of the natural environment on Al-2 signaling. Like AHLs, production of Al-2 may dependent on the particular strain, on the growth phase, or on the culture medium (Bassler 2002, Xavier and Bassler 2005). The Al-2 signal appears to be a relatively stable molecule in comparison with AHLs (Van Mooy et al. 2012). In contrast to AHLs, it appears that $\mathrm{pH}$ does not directly impact the Al-2 signaling molecule (DeKeersmaecker and Vanderleyden 2003). The precursor to all Al-2 signals is 4,5,-dihydroxy2,3-pentanedione (DPD), which converts via spontaneous cyclization and hydration reactions to several DPD derivative molecules which act as Al-2 signals (Schauder et al. 2001, Chen et al. 2002). The local microenvironment may impact the ratio of the furanosyl esters (Horswill et al. 2007) and it has been suggested that the availability of borate could shift this ratio toward the Vibrio harveyi Al-2 signal (Miller et al. 2004). Approximately $71 \%$ of the CFs from BBD isolates 
and $\sim 68 \%$ of the CFs of isolates from the SML of BBD-infected corals tested positive for AI-2. Comparatively, only $\sim 33 \%$ of the CFs of isolates from the SML of apparently healthy corals tested positive for Al-2 production and none of the cyanobacterial CFs tested positive in the Al-2 assay. Thus, it is possible that $\mathrm{Al}-2$ signaling may be occurring more frequently within the BBD microbial consortium and within the SML of diseased corals than in the SML of a healthy coral host.

While this study did not target the phenomenon of quorum quenching, one CF (from BSML-FTL-7j) was observed to inhibit luminescence in the Vibrio harveyi BB170 reporter strain without affecting growth of the culture (Figure 8). Thus, this isolate must be producing and excreting a substance that inhibits light production in the $V$. harveyi BB170 reporter strain. Certain bacteria have been shown to internalize extracellular AI-2 and subsequently degrade the Al-2 signal. For instance, Escherichia coli and Salmonella typhimurium use an ABC transporter to import Al-2 and then enzymatically inactivate the signal molecule (Taga et al. 2001, 2003), thereby removing Al-2 from the external environment (Surette et al. 1999, Federle and Bassler 2003). Because AI-2 is an interspecies QS signal, these species can alter the signaling environment to appear like a low cell density environment. Thus, this process may be used to promote a low cell density phenotype in neighboring bacteria (Federle and Bassler 2003).

\section{Allelopathy among Isolates from BBD and Coral SML}

This study examined several potential growth interactions among members of the BBD consortium and the coral SML. Specifically, interactions among 19 isolates (eight from BBD, six from the SML of BBD-infected corals, and five from apparently healthy corals) were investigated. Nine of the 19 isolates examined tested positive in the AHL assays. Approximately $27 \%$ of the 342 growth challenges conducted in this study resulted in significant inhibition of bacterial growth. Culturable bacteria isolated from the BBD mat and from the SML of BBD-infected and apparently healthy corals are capable of producing and excreting growth-inhibiting compounds (e.g., toxins or antibiotics). While previous studies have detected increased antimicrobial production in the mucus of healthy corals, as opposed to diseased corals (Ritchie 2006, Nissimov et al. 2009), in this study no significant difference in antimicrobial production was detected based on isolate 
source (BBD, SML of BBD-infected coral, SML of healthy coral). Likewise, no significant difference in antimicrobial production was observed based on AHL-signal production (AHLpositive isolate vs. AHL-negative isolate).

In addition to the growth challenge results, antimicrobial activity was observed in the AHL and $\mathrm{Al}-2$ assays. Fifteen CFs inhibited the growth of the Chromobacterium violaceum CV026 reporter strain during the patch test and CF assays and seven CFs inhibited the growth of the Vibrio harveyi BB170 reporter (Table 9). Growth inhibition of C. violaceum CV026 was more frequently observed in the patch test assays than in the CF assays. Of the 15 isolates that inhibited C. violaceum CV026 growth, 12 showed inhibition during the patch tests and only three showed inhibition during the CF assays. One isolate inhibited growth of the C. violaceum CV026 reporter strain in both the patch test and the CF assay. Cultivation parameters (e.g., surface growth vs. planktonic growth) are known to affect the production of antibiotics. Because these isolates are growing on a surface layer (BBD mat and coral SML), they are likely producing antibiotics or toxins that impact the growth of neighboring bacteria.

Antimicrobial compounds have been documented previously in BBD, as well as in coral mucus and coral-associated bacteria. Cyanobacteria isolated from BBD have been shown to produce antibacterial compounds and toxins that impact other BBD mat bacteria, as well as coralassociated bacteria (Richardson et al. 2007, 2009, Gantar et al. 2009, Stanić et al. 2011). Antimicrobial compounds have been identified in environmental samples and isolates from microbial mats in varied environments, including Antarctic lakes (Rojas et al. 2009), tropical hypersaline ponds (Socha et al. 2007), and hot springs (Dobretsov et al. 2011). It is likely that antimicrobial production may contribute to the temporal and spatial dynamics occurring in BBD (Matz 2011). Several studies have demonstrated the presence of antimicrobial activity in scleractinian corals and their associated microbial communities. Koh (1997) found that coral extracts from 100 scleractinian coral species from the Great Barrier Reef tested positive for antibacterial activity against at least one bacterium. Pocillopora damicornis has been shown to release bactericidal compounds following mechanical stress (Geffen and Rosenberg 2005). 
Antagonistic interactions were observed between bacterial isolates from the SML of Montastrea annularis (Rypien et al. 2010). Ritchie (2006) found that in Acropora palmata, both the coral SML itself and bacterial isolates from the SML displayed antimicrobial activity against potentially invasive microbes, including the coral pathogen Serratia marcescens.

\section{Potential Roles of Signaling and Allelopathy in BBD and Coral SML}

This study demonstrated that AHLs are present within active BBD and also that members of the SML of corals and the BBD microbial consortium are capable of producing QS molecules and eliciting antimicrobial activity. While the role of QS in BBD and in coral microbial communities remains unresolved at this time, QS may be involved in a variety of potential behaviors. AHL production may contribute to virulence in the BBD microbial consortium, given that $\mathrm{AHL}$ signaling has been linked to a variety of behaviors involved in pathogenesis, such as biofilm formation, expression of virulence factors, and exoenzyme production (Joint et al. 2007a, Higgins et al. 2007). The Al-2 signals are also associated with disease function in pathogenic bacteria, including protease production, toxin production, and antibiotic production (reviewed in Bandara et al. 2012 and Xavier and Bassler 2003). Stimulation of such virulence factors in the BBD mat may be significant to the disease. For instance, toxin (i.e., microcystin) production by BBD cyanobacteria, implicated as a factor in coral tissue death, could be regulated by QS systems. Recognition of the Al-2 signal might be used by bacteria within the BBD consortium to regulate genes required for survival in mixed species communities or to regulate genes associated with pathogenesis (Parker and Sperandino 2009). Knock-out mutants for luxS have been shown to impact virulence factor expression in a variety of pathogens (reviewed in Sun et al. 2004). Also, Al-2 has been found to regulate the transcription of exopolysaccharides, which are important virulence components for many pathogens (DeLisa et al. 2001). Regulation of bacterial relationships within complex microbial communities is another potential role of $\mathrm{Al}-2$ in the natural environment (Bandara et al. 2012), suggesting that the role(s) of Al-2 in the BBD microbial mat and in the microbial communities of the coral SML may be highly complex. 
It is conceivable that the presence of QS signals within the BBD mat and coral SML could act as a chemical attractant to microbes, allowing for recruitment to these communities. Both synthetic and naturally produced AHLs have been shown to act as a settlement cue for various marine algae (Huang et al. 2007, Joint et al. 2007b, Mohamed et al. 2008, Tait et al 2005). Sato et al. (2010) observed cyanobacterial and bacterial shifts during development of BBD from cyanobacterial patches on corals on the Great Barrier Reef, Australia. Quorum sensing might be one of the drivers affecting progressive development and microbial constituents of the BBD mat.

Under natural conditions, bacteria in the BBD mat and in the coral SML are part of interacting multi-species communities. These dense arrangements of microbes would allow for both symbiotic and competitive relationships among bacteria (Matz 2011). The ability of bacteria to produce antimicrobial compounds is widely believed to provide the producer with a competitive advantage over neighboring bacteria (Wiener 1996, Riley and Gordon 1999, Rao et al. 2005, Berry et al. 2008). The substantial number of inhibitory interactions documented in the current study suggests a high level of competition among bacteria in the BBD mat and the coral SML. Bacterial competition may be one factor contributing to the high microbial diversity previously found in the BBD consortium (see Miller and Richardson 2011) and in coral-associated bacterial communities (Rohwer et al. 2001, 2002, Bourne and Munn 2005, Koren and Rosenberg 2006). High bacterial diversity has also been observed in microbial mats in other environments (Ley et al. 2006, Bolhuis and Stal 2011).

Both cooperative and competitive interactions within the microbial communities of the coral holobiont are widely believed to be important contributors to the health of the host coral (Ritchie 2006, Reshef et al. 2006, Rosenberg et al. 2007, Teplitski and Ritchie 2009, Alagely 2011). The in situ production of antimicrobials and QS signals by the microbial communities in the coral SML and/or by members of the BBD microbial consortium may contribute substantially to these interactions. The microbial community of the coral SML is believed to provide the coral with protection from pathogens via antimicrobial production and/or interspecific competition (Rohwer et al. 2002, Reshef et al. 2006, Ritchie 2006). Interestingly, only 2\% of the 342 growth 
challenges exhibited significant growth stimulation by the culture filtrates, and the vast majority $(\sim 88 \%)$ of these stimulatory CFs were from BBD isolates. This might suggest that cooperation between microbes is more common in interactions among members of the BBD than among SML bacteria.

The focus of this thesis was to investigate microbial interactions within and among members of the BBD consortium and the coral SML. The QS screening assays detected the production of QS signals by culturable members of the BBD consortium and bacterial inhabitants of coral SML. In addition, the BBD mat itself was shown to contain QS signal molecules. Antagonistic interactions were also observed among the bacteria investigated. Thus, it is likely that chemical interactions, including chemical signaling and antimicrobial production, are actively occurring within, and possibly between, these microbial communities. This is the first study to identify QS signals in association with active coral disease. 


\section{LITERATURE CITED}

Alagely A, Krediet CJ, Ritchie KB, Teplitski M. (2011). Signaling-mediated cross-talk modulates swarming and biofilm formation in a coral pathogen Serratia marcescens. ISME J 5:1609-1620.

Altschul SF, Gish W, Miller W, Myers EW, Lipman DJ. (1990). Basic local alignment search tool. J Mol Biol 215:403-410.

Alvarez-Filip L, Dulvy NK, Gill JA, Cote IM, Watkinson AR. (2009). Flattening of Caribbean coral reefs: region-wide declines in architectural complexity. Proc R Soc B 276:3019-3025.

Antonius A. (1976). New observations on coral destruction in reefs. Abstract, Proc 10th Meeting Assoc Is Mar Labs Carib 10:17.

Antonius A. (1981). Coral reef pathology: a review. Proc 4th Int Coral Reef Sym 2:3-6.

Aronson RB, Precht WF. (2001a). Evolutionary Paleoecology of Caribbean Coral Reefs. In: Allmon WD, Bottjer DJ (eds). Evolutionary Paleoecology: The Ecological Context of Macroevolutionary Change. Columbia University Press: New York, pp 171-233.

Aronson RB, Precht WF. (2001b). White band disease and the changing face of Caribbean coral reefs. Hydrobiologia 460:24-38.

Arotsker L, Siboni N, Ben-Dov E, Kramarsky-Winter E, Loya Y, Kushmaro A. (2009). Vibrio sp. as a potentially important member of the Black Band Disease (BBD) consortium in Favia sp. corals. FEMS Micro Ecol 70:515-524.

Auger S, Krin E, Aymerich S, Gohar M. (2006). Autoinducer 2 Affects Biofilm Formation by Bacillus cereus. Appl Environ Microbiol 72:937-941.

Bachofen R, Schenk A. (1998). Quorum sensing autoinducers: Do they play a role in natural microbial habitats? Microbiol Res 153:61-63.

Bakkiyaraj D, Sivasankar C, Pandian SK. (2012). Inhibition of quorum sensing regulated biofilm in Serratia marcescens callusing nosocomial infections. Bioorg Med Chem Lett 22:3089-3094.

Bandara HMHN, Lam OLT, Jin LJ, Lakshman S. (2012). Microbial chemical signaling: a current perspective. Crit Rev Microbiol 38:217-249.

Barneah O, Ben-Dov E, Kramarsky-Winter E, Kushmaro A. (2007). Characterization of black band disease in Red Sea stony corals. Env Micro 9:1995-2006.

Barrios AFG, Zuo R, Hashimoto Y, Yang L, Bentley WE, Wood TK. (2006). Autoinducer 2 controls biofilm formation in Escherichia coli through a novel motility quorum-sensing regulator (MqsR, B3022). J Bacteriol 188:305-316.

Bassler BL. (1999). How bacteria talk to each other: regulation of gene expression by quorum sensing. Curr Opin Microbiol 2:582-587.

Bassler BL. (2002). Small talk. Cell-to-cell communication in bacteria. Cell 109:421-424.

Bassler BL, Greenberg EP, Stevens AM. (1997). Cross-species induction of luminescence in the quorum-sensing bacterium Vibrio harveyi. J Bacteriol 179:4043-4045. 
Bassler BL, Wright M, Silverman MR. (1994). Multiple signalling systems controlling expression of luminescence in Vibrio harveyi: sequence and function of genes encoding a second sensory pathway. Mol Microbiol 13:273-286.

Bassler BL, Wright M, Showalter RE, Silverman MR. (1993). Intercellular signalling in Vibrio harveyi: sequence and function of genes regulating expression of luminescence. Mol Microbiol 9:773-786.

Beck von Bodman S, Hayman GT, Farrand SK. (1992). Opine catabolism and conjugal transfer of the nopaline Ti plasmid pTiC58 are coordinately regulated by a single repressor. Proc Natl Acad Sci USA 89:643-647.

Bellwood DR, Hughes TP, Folke C, Nystrom M. (2004). Confronting the coral reef crisis. Nature 429:827-833.

Berry JP, Gantar M, Perez MH, Berry G, Noriega FG. (2008). Cyanobacterial toxins as allelochemicals with potential applications as algaecides, herbicides, and insecticides. Mar Drugs 6:117-146.

Bodor A, Elxnat B, Thiel V, Schulz S, Wagner-Dobler I. (2008). Potential for luxS related signalling in marine bacteria and production of autoinducer-2 in the genus Shewanella. BMC Microbiol 8:13.

Bolhuis H, Stal LJ. (2011). Analysis of bacterial and archaeal diversity in coastal microbial mats using massive parallel 16S rRNA gene tag sequencing. ISME J 5:1701-1712.

Borger JL. (2005). Scleractinian coral diseases in south Florida: incidence, species susceptibility, and mortality. Dis Aquat Organ 67:249-258.

Bourne DG, Garren M, Work TM, Rosenberg E, Smith GW, Harvell CD. (2009). Microbial disease and the coral holobiont. Trends Microbiol 17:554-562.

Bourne D, lida Y, Uthicke S, Smith-Keune C. (2008). Changes in coral-associated microbial communities during a bleaching event. ISME J 2:350-363.

Bourne DG, Munn CB. (2005). Diversity of bacteria associated with the coral Pocillopora damicornis from the Great Barrier Reef. Environ Microbiol 7:1162-1174.

Boyer M, Wisniewski-Dyé F. (2009). Cell-cell signaling in bacteria: not simply a matter of quorum. FEMS Microbiol Ecol 70:1-19.

Brown BE, Bythell JC. (2005). Perspectives on mucus secretion in reef corals. Mar Ecol Prog Ser 296:291-309.

Bruckner AW, Bruckner RJ, Williams EH. (1997). Spread of a black band disease epizootic through the coral reef ecosystem in St. Ann's Bay, Jamaica. Bull Mar Sci 61:919-928.

Bruckner AW, Bruckner RJ. (1997). The persistence of black-band disease in Jamaica: impact on community structure. Proc 8th Int Coral Reef Sym 1:601-606.

Bruno JF, Selig ER. (2007). Regional decline of coral cover in the Indo-Pacific: timing, extent, and subregional comparisons. PLoS ONE 2:e711. 
Bruno JF, Selig ER, Casey KS, Page CA, Willis BL, Harvell CD, Sweatman H, Melendy AM. (2007). Thermal stress and coral cover as drivers of disease outbreaks. PloS Biol 5(6):12201227.

Burgess NA, Kirke DF, Williams P, Winzer K, Hardie KR, Meyers NL, Aduse-Opoku J, Curtis MA, Cámara M. (2002). LuxS-dependent quorum sensing in Porphyromonas gingivalis modulates protease and haemagglutinin activities but is not essential for virulence. Microbiology 148:763772.

Buch C, Sigh J, Nielsen J, Larsen JL, Gram L. (2003). Production of acylated homoserine lactones by different serotypes of Vibrio anguillarum both in culture and during infection of rainbow trout. Syst Appl Microbiol 26:338-349.

Burke L, Reytar K, Spalding M, Perry A. (2011). Reefs at Risk Revisited. World Resources Institute: Washington, DC.

Byers JT, Lucas C, Salmond GPC, Welch M. (2002). Nonenzymatic turnover of an Erwinia carotovora quorum sensing signaling molecule. J Bacteriol 184:1163-1171.

Bythell JC, Barer MR, Cooney RP, Guest JR, O'Donnell AG, Pantos O, Le Tissier MD. (2002). Histopathological methods for the investigation of microbial communities associated with disease lesions in reef corals. Lett Appl Microbiol 34:359-364.

Carlton RG, Richardson LL. (1995). Oxygen and sulfide dynamics in a horizontally migrating cyanobacterial mat: Black band disease of corals. FEMS Microbiol Ecol 18:155-162.

Casamatta D, Stanić D, Gantar M, Richardson LL. (2012). Characterization of Roseofilum reptotaenium (Oscillatoriales, Cyanobacteria) gen. et sp. nov. isolated from Caribbean black band disease. Phycologia 51:489-499.

Case RJ, Longford SR, Campbell AH, Low A, Tujula N, Steinberg PD, Kjelleberg S. (2011). Temperature induced bacterial virulence and bleaching disease in a chemically defended marine macroalga. Environ Microbiol 13:529-537.

Cha C, Gao P, Chen Y, Shaw PD, Farrand SK. (1998). Production of acyl-homoserine lactone quorum-sensing signals by Gram-negative plant-associated bacteria. Mol Plant-Microb Int 11:1119-1129.

Charlton TS, de Nys R, Netting A, Kumar N, Hentzer M, Givskov M, Kjelleberg S. (2000). A novel and sensitive method for the quantification of $\mathrm{N}$-3-oxoacyl homoserine lactones using gas chromatography-mass spectrometry: application to a model bacterial biofilm. Environ Microbiol 2:530-541.

Chen X, Schauder S, Potier N, Van Dorsselaer A, Pelczer I, Bassler BL, Hughson FM. (2002). Structural identification of a bacterial quorum-sensing signal containing boron. Nature 415:545549.

Chhabra SR, Phillip B, Eberl L, Givskov M, Williams P, Cámara M. (2005). Extracellular communication in bacteria. Top Curr Chem 240:279-315.

Chilton M, Currier TC, Farrand SK, Bendich AJ, Gordon MP, Nester EW. (1974). Agrobacterium tumefaciens DNA and PS8 bacteriophage DNA not detected in crown gall tumors. Proc Natl Acad Sci USA 71:3672-3676. 
Cooney RP, Pantos O, Le Tissier MD, Barer MR, O'Donnell AG, Bythell JC. (2002).

Characterization of the bacterial consortium associated with black band disease in coral using molecular microbiological techniques. Environ Microbiol 4:401-413.

Davies DG, Parsek MR, Pearson JP, Iglewski BH, Costerton JW, Greenberg EP. (1998). The involvement of cell-to-cell signals in the development of a bacterial biofilm. Science 280:295-298.

Decho AW, Norman RS, Visscher PT. (2010). Quorum sensing in natural environments: emerging views from microbial mats. Trends in Mircrobiol 18:73-80.

Decho AW, Visscher PT, Ferrj J, Kawaguchi T, He L, Przekop KM, Norman RS, Reid RP. (2009). Autoinducers extracted from microbial mats reveal a surprising diversity of $\mathrm{N}$-acylhomoserine lactones (AHLs) and abundance changes that may relate to diel pH. Environ Microbiol 11:409_ 420.

De Keersmaecker SC, Sonck K, Vanderleyden J. (2006). Let LuxS speak up in Al-2 signaling. Trends Microbiol 14:114-119.

De Keersmaecker SCJ, Vanderleyden J. (2003). Constraints on detection of autoinducer-2 (AI-2) signalling molecules using Vibrio harveyi as a reporter. Microbiol 149:1953-1956.

de Kievit TR, Iglewski BH. (2000). Bacterial quorum sensing in pathogenic relationships. Infect Immun 68:4839-4849.

DeLisa MP, Wu CF, Wang L, Valdes JJ, Bentley WE. (2001). DNA microarray-based identification of genes controlled by autoinducer 2-stimulated quorum sensing in Escherichia coli. J Bacteriol 183:5239-5247.

Dobretsov S, Abed RMM, Maskari SMS, Sabahi JN, Victor R. (2011). Cyanobacterial mats from hot springs produce antimicrobial compounds and quorum-sensing inhibitors under natural conditions. J Appl Phycol 23:983-993.

Done TJ. (1992). Phase shifts in coral reef communities and their ecological significance. Hydrobiologia 247:121-132.

Dong Y, Zhang L. (2005). Quorum-sensing and quorum-quenching enzymes. J Microbiol 43:101109.

Donlan RM, Costerton JW. (2002). Biofilms: survival mechanisms of clinically relevant microorganisms. Clin Microbiol Rev 54:167-193.

Ducklow HW, Mitchell R. (1979). Bacterial populations and adaptations in the mucus layers on living corals. Limnol Oceanogr 24:715-725.

Eberhard A, Burlingame AL, Eberhard C, Kenyon GL, Nealson KH, Oppenheimer NJ. (1981). Structural identification of autoinducer of Photobacterium fischeri luciferase. Biochemistry 20:2444-2449.

Edmunds PJ. (1991). Extent and effect of black-band disease on a Caribbean reef. Coral Reefs 10:161-165.

Edmunds PJ. (2000). Recruitment of scleractinians onto the skeletons of coarls killed by black band disease. Coral Reefs 19:69-74. 
Ellner SP, Jones LE, Mydlarz LD, Harvell CD. (2007). Within-host disease ecology in the sea fan Gorgonia ventalina: modeling the spatial immunodynamics of a coral-pathogen interaction. Am Nat 170:E143-E161.

Farrand SK, Qin Y, Oger P. (2002). Quorum-sensing system of Agrobacterium plasmids: analysis and utility. Methods Enzymol 358:452-484.

Federle MJ, Bassler BL. (2003). Interspecies communication in bacteria. J Clin Investig 112:1291-1299.

Frias-Lopez J, Bonheyo GT, Jin Q, Fouke BW. (2003). Cyanobacteria associated with coral black band disease in Caribbean and Indo-Pacific reefs. Appl Environ Microbiol 69:2409-2413.

Frias-Lopez J, Klaus JS, Bonheyo GT, Fouke BW. (2004). Bacterial community associated with black band disease in corals. Appl Environ Microbiol 70:5955-5962.

Frias-Lopez J, Zerkle AL, Bonheyo GT, Fouke BW. (2002). Partitioning of bacterial communities between seawater and healthy, black band diseased, and dead coral surfaces. Appl Environ Microbiol 68:2214-2228.

Fuhrman JA, Campbell L. (1998). Marine ecology - microbial diversity. Nature 393:410-411.

Fuqua C, Parsek MR, Greenberg EP. (2001). Regulation of gene expression by cell-to-cell communication: acyl-homoserine lactone quorum sensing. Annu Rev Genet 35:439-468.

Fuqua WC, Winans SC, Greenberg EP. (1994). Quorum sensing in bacteria: the LuxR-Luxl family of cell density-responsive transcriptional regulators. J Bacteriol 176:269-275.

Gantar M, Kaczmarsky LT, Stanić D, Miller AW, Richardson LL. (2011). Antibacterial activity of marine and black band disease cyanobacteria against coral-associated bacteria. Mar Drugs 9:2085-2109

Gantar M, Sekar R, Richardson LL. (2009). Cyanotoxins from black band disease of corals and from other coral reef environments. Microb Ecol 58:856-864.

García-Aljaro C, Vargas-Cespedes GJ, Blanch AR. (2012). Detection of acylated homoserine lactones produced by Vibrio spp. and related species isolated from water and aquatic organisms. J Appl Microbiol 112:383-389.

Gardner TA, Cote IM, Gill JA, Grant A, Watkinson AR. (2003). Long-term region-wide declines in Caribbean corals. Science 301:958-960.

Garrett P, Ducklow H. (1975). Coral disease in Bermuda. Nature 253:349-350.

Gauthier MJ. (1976). Morphological, physiological, and biochemical characteristics of some violetpigmented bacteria isolated from seawater. Can J Microbiol 22:138-149.

Gauthier MJ. (1982). Validation of the name Alteromonas luteoviolacea. Int J Syst Bacteriol 32:82-86.

Geffen Y, Rosenberg E. (2005). Stress-induced rapid release of antibacterials by scleractinian corals. Mar Biol 146:931-935. 
Gera C, Srivastava S. (2006). Quorum-sensing: The phenomenon of microbial communication. Curr Sci 90:666-677.

Gerwick L, Boudreau P, Choi H, Mascuch S, Villa FA, Balunas MJ, Malloy KL, Teasdale ME, Rowley DC, Gerwick WH. (2012). Interkingdom signaling by structurally related cyanobacterial and algal secondary metabolites. Phytochem Rev 2012; e-pub ahead of print 30 May 2012, doi: $10.1007 / \mathrm{s} 11101-012-9237-5$.

Glas MS, Sato Y, Ulstrup KE, Bourne DG. (2012). Biogeochemical conditions determine virulence of black band disease of corals. ISME J 6:1526-1534.

Golberg K, Eltzov E, Shnit-Orland M, Marks RS, Kushmaro A. (2011). Characterization of quorum sensing signals in coral-associated bacteria. Microb Ecol 61:783-792.

Gomez-Gil B, Thompson FL, Thompson CC, Swings J. (2003). Vibrio rotiferianus sp. nov., isolated from cultures of the rotifer Brachionus plicatilis. Int. J Syst Evol Microbiol 53:239-243.

Gonzalez JE, Keshavan ND. (2006). Messing with bacterial quorum sensing. Microbiol and Molec Biol Rev 70:859-875.

Gram L, Grossart H, Schlingloff A, Kiorboe T. (2002). Possible quorum sensing in marine snow bacteria: production of acylated homoserine lactones by Roseobacter strains isolated from marine snow. Appl Environ Microbiol 68:4111-4116.

Green DH, Edmunds PJ, Carpenter RC. (2008). Increasing relative abundance of Porites astreoides on Caribbean reefs mediated by an overall decline in coral cover. Mar Ecol Prog Ser 359:1-10.

Green EP, Bruckner AW. (2000). The significance of coral disease epizootiology for coral reef conservation. Biol Cons 96:347-361.

Greenberg EP, Hastings JW, Ulitzur S. (1979). Induction of luciferase synthesis in Beneckea harveyi by other marine bacteria. Arch Microbiol 120:87-91.

Guppy R, Bythell JC. (2006). Environmental effects on bacterial diversity in the surface mucus layer of the reef coral Montastraea faveolata. Mar Ecol Prog Ser 328:133-142.

Han XG, Lu CP. (2009). Detection of Autoinducer-2 and analysis of the profile of luxS and pfs transcription in Streptococcus suis serotype 2. Curr Microbiol 58:146-152.

Harvell CD, Altizer S, Cattadori IMM, Harrington L, Weil E. (2009). Climate change and wildlife disease: When does the host matter most? Ecology 90:912-920.

Harvell CD, Kim K, Burkholder JM, Colwell RR, Epstein PR, Grimes DJ, Hofmann EE, Lipp EK, Osterhaus ADME, Overstreet RM, Porter JW, Smith GW, Vasta GR. (1999). Emerging marine diseases - climate links and anthropogenic factors. Science 285:1505-1509.

Harvell CD, Jordan-Dahlgren E, Merkel S, Raymundo L, Rosenberg E, Smith G, Weil E, Willis B. (2007). Coral disease, environmental drivers and the balance between coral and microbial associates. Oceanography 20:58-81.

Hayes RL, Goreau TJ. (1998). The significance of emerging diseases in the tropical coral reef ecosystem. Rev Biol Trop 46:173-185. 
Henke JM, Bassler BL. (2004a). Three parallel quorum-sensing systems regulate gene expression in Vibrio harveyi. J Bacteriol 186:6902-6914.

Henke JM, Bassler BL. (2004b). Quorum sensing regulates type III secretion in Vibrio harveyi and Vibrio parahaemolyticus. J Bacteriol 186:3794-3805.

Higgins DA, Pomianek ME, Kraml CM, Taylor RK, Semmelhack MF, Bassler BL. (2007). The major Vibrio cholerae autoinducer and its role in virulence factor production. Nature 450:883-886.

Horswill AR, Stoodley P, Stewart PS, Parsek MR. (2007). The effect of the chemical, biological, and physical environment on quorum sensing in structured microbial communities. Anal Bioanal Chem 387:371-380.

Huang YL, Dobretsov S, Ki JS, Yang LH, Qian PY. (2007). Presence of acyl-homoserine lactone in subtidal biofilm and the implication in larval behavioral response in the polychaete Hydroides elegans. Microb Ecol 54:384-392.

Huang YL, Ki JS, Case RJ, Qian P. (2008). Diversity and acyl-homoserine lactone production among subtidal biofilm-forming bacteria. Aquat Microb Ecol 52:185-193.

Huang YL, Ki JS, Lee OO, Qian P. (2009). Evidence for the dynamics of Acyl homoserine lactone and AHL-producing bacteria during subtidal biofilm formation. ISME J 3:296-304.

Huber B, Riedel K, Hentzer M, Heydorn A, Gotsclich A, Givskov M, Molin S, Eberl L. (2001). The cep quorum-sensing system of Burkholderia cepacia $\mathrm{H} 111$ controls biofilm formation and swarming motility. Microbiology 147:2517-2528.

Isnansetyo A, Kamei Y. (2003). Pseudoalteromonas phenolica sp. nov., a novel marine bacterium that produces phenolic anti-methicillin-resistant Staphylococcus aureus substances. Int J Syst Evol Microbiol 53:583-588.

Jayaraman A, Wood TK. (2008). Bacterial quorum sensing: signals, circuits, and implications for biofilms and disease. Annu Rev Biomed Eng 10:145-167.

Jean W, Huang SP, Liu TY, Chen JS, Shieh WY. (2009). Aliagarivorans marinus gen. nov., sp. nov. and Aliagarivorans taiwanensis sp. nov., facultatively anaerobic marine bacteria capable of agar degradation. Int J Syst Evol Microbiol 59:1880-1887.

Johnson FH, Shunk IV. (1936). An interesting new species of luminous bacteria. J Bact 31:585593.

Joint I, Downie JA, Williams P. (2007a). Bacterial conversations: talking, listening and eavesdropping. An introduction. Phil Trans R Soc B 362:1115-1117.

Joint I, Tait K, Wheeler G. (2007b). Cross-kingdom signalling: exploitation of bacterial quorum sensing molecules by the green seaweed Ulva. Philos Trans R Soc Lond B 362:1223-1233.

Jones MB, Blaser MJ. (2003). Detection of a luxS-signaling molecule in Bacillus anthracis. Infect Immun 71:3914-3919.

Jones RJ, Bowyer J, Hoegh-Guldberg O, Blackall LL. (2004). Dynamics of a temperature-related coral disease outbreak. Mar Ecol Prog Ser 281:63-77. 
Kaczmarsky LT, Draud M, Williams EH. (2005). Is there a relationship between proximity to sewage effluent and the prevalence of coral disease? Carib J Sci 41:124-137.

Knowlton N. (2001). The future of coral reefs. Proc Natl Acad Sci USA 98:5419-5425.

Koh KS. (1997). Do scleractinian corals engage in chemical warefare against microbes? J Chem Ecol 23:379-398.

Kooperman N, Ben-Dov E, Kramarsky-Winter E, Barak Z, Kushmaro A. (2007). Coral mucusassociated bacterial communities from natural and aquarium environments. FEMS Microbiol Lett 276:106-113.

Koren O, Rosenberg E. (2006). Bacteria associated with mucus and tissues of the coral Oculina patagonica in summer and winter. Appl Environ Microbiol 72:5254-5259.

Kuta KG, Richardson LL. (1996). Abundance and distribution of black band disease of corals in the northern Florida Keys. Coral Reefs 15:219-223.

Kuta KG, Richardson LL. (1997). Black band disease and the fate of diseased coral colonies in the Florida Keys. Proc 8th Int Coral Reef Sym 1:575-578.

Labbate M, Queck SY, Koh KS, Rice SA, Givskov M, Kjelleberg S. (2004). Quorum sensingcontrolled biofilm development in Serratia liquefaciens MG1. J Bacteriol 186:692-698.

Leadbetter JR, Greenberg EP. (2000). Metabolism of acyl-homoserine lactone quorum-sensing signals by Variovorax paradoxus. J Bacteriol 182:6921-6926.

Ley RE, Harris JK, Wilcox J, Spear JR, Miller SR, Bebout BM, Maresca JA, Bryant DA, Sogin ML, Pace NR. (2006). Unexpected diversity and complexity of the Guerrero Negro hypersaline microbial mat. Appl Environ Microbiol 72:3685-3695.

Lichstein HC, Van De Sand VF. (1946). The antibiotic activity of violacein, prodigiosin, and phthiocol. J Bacteriol 52:145-146.

Matz C. (2011). Competition, Communication, Cooperation: Molecular Crosstalk in Multi-species Biofilms. In: Flemming HC, Wingender J, Szewzyk U (eds). Biofilm Highlights, Springer Series on Biofilms, Vol. 5. Springer-Verlag: Berlin, pp 29-40.

McClean KH, Winson MK, Fish L, Taylor A, Chhabra SR, Cámara M, Daykin M, Lamb JH, Swift S, Bycroft BW, Stewart GSAB, Williams P. (1997). Quorum sensing and Chromobacterium violaceum: exploitation of violacein production and inhibition for the detection of $N$ acylhomoserine lactones. Microbiology 143:3703-3711.

McDougald D, Srinivasan S, Rice SA, Kjelleberg S. (2003). Signal-mediated cross-talk regulates stress adaptation in Vibrio species. Microbiol 149:1923-1933.

McGowan SJ, Barnard AML, Bosgelmez G, Sebaithia M, Simpson MJL, Thomson NR, Todd DE, Welch M, Whitehead MA, Salmond GPC. (2005). Carbapenem antibiotic biosynthesis in Erwinia carotovora is regulated by physiological and genetic factors modulating the quorum sensingdependent control pathway. Molec Microbiol 55:526-545.

Meikle P, Richards GN, Yellowlees D. (1988). Structural investigations on the mucus from six species of coral. Mar Biol 99:187-193. 
Meron D, Atias E, Kruh LI, Elifantz H, Minz D, Fine M, Banin E. (2011). The impact of reduced pH on the microbial community of the coral Acropora eurystoma. ISME J 5:51-60.

Miller AW, Richardson LL. (2011). A meta-analysis of 16S rRNA gene clone libraries from the polymicrobial black band disease of corals. FEMS Micro Ecol 75:231-241.

Miller MB, Bassler BL. (2001). Quorum sensing in bacteria. Annu Rev Microbiol 55:165-199.

Miller ST, Xavier KB, Campagna SR, Taga ME, Semmelhack MF, Bassler BL, Hughson FM. (2004). Salmonella typhimurium recognizes a chemically distinct form of the bacterial quorumsensing signal Al-2. Molecular Cell 15:677-687.

Mitchell R, Chet I. (1975). Bacterial attack of corals in polluted seawater. Microb Ecol 2:227-233.

Mohamed NM, Cicirelli EM, Kan J, Chen F, Fuqua C, Hill RT. (2008). Diversity and quorumsensing signal production of Proteobacteria associated with marine sponges. Env Microbiol 10:75-86.

Mouchka ME, Hewson I, Harvell D. (2010). Coral-associated bacterial assemblages: current knowledge and the potential for climate-driven impacts. Integr Comp Biol 50:662-674.

Muyzer G, Teske A, Wirsen CO, Jannasch HW. (1995). Phylogenetic relationship of Thiomicrospira species and their identification in deep-sea hydrothermal vent samples by denaturing gradient gel electrophoresis of 16S rDNA fragments. Arch Microbiol 164:165-172.

Myers JL, Richardson LL. (2009). Adaptation of cyanobacteria to the sulfide-rich microenvironment of black band disease of coral. FEMS Microbiol Ecol 67:242-251.

Myers JL, Sekar R, Richardson LL. (2007). Culture, DGGE analysis, and molecular identification of the cyanobacteria Geitlerinema and Leptolyngbya in black band disease of corals. Appl Environ Microbiol 73:5173-5182.

Nealson KH. (1977). Autoinduction of bacterial luciferase. Occurrence, mechanism and significance. Arch Microbiol 112:73-79.

Nissimov J, Rosenberg E, Munn CB. (2009). Antimicrobial properties of resident coral mucus bacteria of Oculina patagonica. FEMS Microbiol Lett 292:210-215.

Novick RP, Geisinger E. (2008). Quorum sensing in staphylococci. Annu Rev Genet 42:541-564.

Parker CT, Sperandio V. (2009). Cell-to-cell signalling during pathogenesis. Cell Microbiol 11:363-369.

Pierson III LS, Wood DW, Pierson EA. (1998). Homoserine lactone-mediated gene regulation in plant-associated bacteria. Annu Rev Phytopathol 36:207-225.

Porter JW, Dustan P, Jaap WC, Patterson KL, Kosmynin V, Meier OW, Patterson ME, Parsons M. (2001). Patterns of spread of coral disease in the Florida Keys. Hydrobiologia 460:1-24.

Ragoonath DN. (2005). Heterotrophic capabilities and the molecular identification of a cyanobacterium found in black band disease of coral reefs, Thesis, Florida International University. 
Ramos-Flores T. (1983). Lower marine fungus associated with black line disease in star corals (Montastraea annularis E. \& S.). Biol Bull 165:429-435.

Rao D, Webb JS, Kjelleber S. (2005). Competitive interactions in mixed-species biofilms containing the marine bacterium Pseudoalteromonas tunicata. Appl Environ Microbiol 71:17291736.

Reshef L, Koren O, Loya Y, Zilber-Rosenberg I, Rosenberg E. (2006). The coral probiotic hypothesis. Env Microbiol 8:2068-2073.

Richardson LL. (1996). Horizontal and vertical migration patterns of Phormidium corallyticum and Beggiatoa spp. associated with black band disease of corals. Microb Ecol 32:323-335.

Richardson LL. (1997). Occurrence of the the black-band disease cyanobacterium on healthy corals of the Florida Keys. Bull Mar Sci 61:485-490.

Richardson LL. (1998). Coral diseases: what is really known? Trends Ecol Evol 13:438-443.

Richardson LL. (2004). Black band disease. In: Rosenberg E, Loya Y (eds). Coral Reef Health and Disease. Springer- Verlag: Berlin, pp 325-336.

Richardson LL, Aronson RB. (2000). Infectious diseases of reef corals. Proc 9th Int Coral Reef Sym 2:1225-1230.

Richardson, LL, Carlton RG. (1993). Behavioral and chemical aspects of black band disease of corals: An In situ field and laboratory study. In: Heine JN, Crane NL (eds). Diving for Science 1993: Proc Amer Acad Underwater Sci 11:107-116.

Richardson LL, Castenholz RW. (1987). Enhanced survival of the cyanobacterium Oscillatoria terebriformis in darkness under anaerobic conditions. Appl Env Microbiol 53:2151-2158.

Richardson LL, Goldberg WM, Kuta KG, Aronson RB, Smith GW, Ritchie KB, Halas JC, Feingold JS, Miller SL. (1998). Florida's mystery coral-killer identified. Nature 392:557-558.

Richardson LL, Kuta KG. (2003). Ecological physiology of the black band disease cyanobacterium Phormidium corallyticum. FEMS Microbiol Ecol 43:287-298.

Richardson LL, Miller AW, Broderick E, Kaczmarsky L, Gantar M, Stanić D, Sekar R. (2009). Sulfide, microcystin, and the etiology of black band disease. Dis Aquat Org 87:79-90.

Richardson LL, Sekar R, Myers J, Gantar M, Voss J, Kaczmarsky L, Remily E, Boyer G, Zimba P. (2007). The presence of the cyanobacterial toxin microcystin in black band disease of corals. FEMS Microbiol Lett 272:182-187.

Richardson LL, Smith GW, Ritchie KB, Carlton RG. (2001). Integrating microbiological, microsensor, molecular, and physiologic techniques in the study of coral disease pathogenesis. Hydrobiologia 460:71-89.

Rickard AH, Palmer RJ, Jr., Blehert DS, Campagna SR, Semmelhack MF, Egland PG, Bassler $\mathrm{BL}$, Kolenbrander PE. (2006). Autoinducer 2: a concentration-dependent signal for mutualistic bacterial biofilm growth. Mol Microbiol 60:1446-1456. 
Riedel K, Hentzer M, Geisenberger O, Huber B, Steidle A, Wu H, Hoiby N, Givskov M, Molin S, Eberl L. (2001). N-acylhomoserine-lactone-mediated communication between Pseudomonas aeruginosa and Burkholderia cepacia in mixed biofilms. Microbiology 147:3249-3262.

Riley MA, Gordon DM. (1999). The ecological role of bacteriocins in bacterial competition. Trends in Microbiol 7:129-133.

Rippka R, Deruelles J, Waterbury JB, Herdman M, Stanier RY. (1979). Generic assignments, strain histories and properties of pure cultures of cyanobacteria. J Gen Microbiol 111:1-61.

Ritchie KB. (2006). Regulation of microbial populations by coral surface mucus and mucusassociated bacteria. Mar Ecol Prog Ser 322:1-14.

Rohwer F, Breitbart M, Jara F, Azam F, Knowlton N. (2001). Diversity of bacteria associated with the Caribbean coral Montastraea franksi. Coral Reefs 20:85-91.

Rohwer F, Seguritan V, Azam F, Knowlton N. (2002). Diversity and distribution of coralassociated bacteria. Mar Ecol Prog Ser 243:1-10.

Rojas JL, Martín J, Tormo JR, Vicente F, Brunati M, Ciciliato I, Losi D, Van Trappen S, Mergaert J, Swings J, Marinelli F, Genilloud O. (2009). Bacterial diversity from benthic mats of Antarctic lakes as a source of new bioactive metabolites. Mar Genomics 2:33-41.

Rosenberg E, Koren O, Reshef L, Efrony R, Zilber-Rosenberg I. (2007). The role of microorganisms in coral health, disease and evolution. Nat Rev Microbiol 5:355-362.

Rosenberg E, Loya Y. (2004). Coral Health and Disease. Springer: Berlin.

Rützler K, Santavy DL, Antonius A. (1983). The black band disease of Atlantic reef corals. III. Distribution, ecology, and development. PSZNI: Mar Ecol 4:329-358.

Ryan RP, Dow JM. (2008). Diffusible signals and interspecies communication in bacteria. Microbiology 154:1845-1858.

Rypien KL, Ward JR, Azam F. (2010). Antagonistic interactions among coral-associated bacteria. Environ Microbiol 12:28-39.

Sato Y, Bourne DG, Willis BL. (2009). Dynamics of seasonal outbreaks of black band disease in an assemblage of Montipora species at Pelorus Island (Great Barrier Reef, Australia). Proc R Soc B Biol Sci 276:2795-2803.

Sato Y, Willis BL, Bourne DG. (2010). Successional changes in bacterial communities during the development of black band disease on the reef coral, Montipora hispida. ISME J 4:203-214.

Schaefer AL, Hanzelka BL, Parsek MR, Greenberg EP. (2000). Detection, purification, and structural elucidation of the acylhomoserine lactone inducer of Vibrio fischeri luminescence and other related molecules. Methods Enzymol 305:288-301.

Schauder S, Shokat K, Surette MG, Bassler BL. (2001). The LuxS family of bacterial autoinducers: biosynthesis of a novel quorum-sensing signal molecule. Molec Micro 41:463-476.

Sekar R, Kaczmarsky LT, Richardson LL. (2008). Microbial community composition of black band disease on the coral host Siderastrea siderea from three regions of the wider Caribbean. Mar Ecol Prog Ser 362:85-98. 
Sekar R, Mills DK, Remily ER, Voss JD, Richardson LL. (2006). Microbial communities in the surface mucopolysaccharide layer and the black band microbial mat of black band-diseased Siderastrea siderea. Appl Environ Microbiol 72:5963-5873.

Shaw PD, Ping G, Daly SL, Cha C, Cronan JE Jr, Rinehart KL, Farrand SK. (1997). Detecting and characterizing $\mathrm{N}$-acyl-homoserine lactone signal molecules by thin-layer chromatography. Proc Natl Acad Sci USA 94:6036-6041.

Shnit-Orland M, Kushmaro A. (2009). Coral mucus-associated bacteria: a possible first line of defense. FEMS Microbiol Ecol 67:371-380.

Sievers F, Wilm A, Dineen D, Gibson TJ, Karplus K, Li W, Lopez R, McWilliam H, Remmert M, Söding J, Thompson JD, Higgins DG. (2011). Fast, scalable generation of high-quality protein multiple sequence alignments using Clustal Omega. Mol Syst Biol 7:539.

Socha AM, Long RA, and Rowley DC. (2007). Bacillamides from a hypersaline microbial mat bacterium. J Nat Prod 70:1793-1795.

Stackebrandt E, Goebel BM. (1994). Taxonomic note: a place for DNA-DNA reassociation and $16 \mathrm{~S}$ rRNA sequence analysis in the present species definition in bacteriology. Int J Syst Bacteriol 44:846-849.

Stanić D, Oehrle S, Gantar M, Richardson LL. (2011). Microcystin production and ecological physiology of Caribbean black band disease cyanobacteria. Environ Microbiol 13:900-910.

Steindler L, Venturi V. (2007). Detection of quorum-sensing $\mathrm{N}$-acyl homoserine lactone signal molecules by bacterial biosensors. FEMS Microbiol Lett 266:1-9.

Sun J, Daniel R, Wagner-Döbler I, Zeng AP. (2004). Is Autoinducer-2 a universal signal for interspecies communication: a comparative genomic and phylogenetic analysis of the synthesis and signal transduction pathways. BMC Evol Biol 4:36.

Surette MG, Miller MB, Bassler BL. (1999). Quorum sensing in Escherichia coli, Salmonella typhimurium, and Vibrio harveyi: a new family of genes responsible for autoinducer production. Proc Natl Acad Sci USA 96:1639-1644.

Sussman M, Bourne DG, Willis BL. (2006). A single cyanobacterial ribotype is associated with both red and black bands on diseased corals from Palau. Dis Aquat Organ 69:111-118.

Sutherland KP, Porter JW, Torres C. (2004). Disease and immunity in Caribbean and Indo-Pacific zooxanthellate corals. Mar Ecol Prog Ser 266:273-302.

Taga ME. (2005). Methods for analysis of bacterial autoinducer-2 production. Curr Protoc Microbiol 1:1C.1.

Taga ME, Miller ST, Bassler BL. (2003). Lsr-mediated transport and processing of Al-2 in Salmonella typhimurium. Mol Microbiol 50:1411-1427.

Taga ME, Semmelhack JL, Bassler BL. (2001). The LuxS-dependent autoinducer Al-2 controls the expression of an ABC transporter that functions in Al-2 uptake in Salmonella typhimurium. Mol Microbiol 42:777-793. 
Tait K, Hutchison Z, Thompson FL, Munn CB. (2010). Quorum sensing signal production and inhibition by coral-associated vibrios. Env Micro Rpt 2:145-15.

Tait K, Joint I, Daykin M, Milton DL, Williams P, Cámara M. (2005). Disruption of quorum sensing in sea water abolishes attraction of zoospores of the green alga Ulva to bacterial biofilms. Environ Microbiol 7:229-240.

Tamura K, Peterson D, Peterson N, Stecher G, Nei M, Kumar S. (2011). MEGA5: molecular evolutionary genetics analysis using maximum likelihood, evolutionary distance, and maximum parsimony methods. Mol Biol Evol 28:2731-2739.

Taylor MW, Schupp PJ, Baillie HJ, Charlton TS, de Nys R, Kjelleberg S, Steinberg PD. (2004). Evidence for acyl homoserine lactone signal production in bacteria associated with marine sponges. Appl Environ Microbiol 70:4387-4389.

Teplitski M, Ritchie K. (2009). How feasible is the biological control of coral diseases? Trends Ecol Evol 24:378-385.

Vandecandelaere I, Nercessian O, Segaert E, Achouak W, Faimali M, Vandamme P. (2008). Ruegeria scottomollicae sp. nov., isolated from a marine electroactive biofilm. Int J Syst Evol Microbiol 58:2726-2733.

Vandecandelaere I, Nercessian O, Segaert E, Achouak W, Mollica A, Faimali M, Vandamme P. (2009). Nautella italica gen. nov., sp. nov., isolated from a marine electroactive biofilm. Int J Syst Evol Microbiol 59:811-817.

Van Houdt R, Givskov M, Michiels CW. (2007). Quorum sensing in Serratia. FEMS Microbiol Rev 31:407-424.

Van Mooy BAS, Hmelo LR, Sofen LE, Campagna SR, May AL, Dyhrman ST, Heithoff A, Webb EA, Momper L, Mincer TJ. (2012). Quorum sensing control of phosphorus acquisition in Trichodesmium consortia. ISME J 6:422-429.

Vargas-Angel B, Thomas JD, Hoke SM. (2003). High-latitude Acropora cervicornis thickets off Fort Lauderdale, Florida, USA. Coral Reefs 22:465-473.

Vega Thurber R, Willner-Hall D, Rodriguez-Mueller B, Desnues C, Edwards RA, Angly F, Dinsdale E, Kelly L, Rohwer F. (2009). Metagenomic analysis of stressed coral holobionts. Env Microbiol 11:2148-2163.

Viehman TS. (2002). Black band disease of corals: ecology and physiology of the sulfur bacteria Desulfovibrio spp. and Beggiatoa spp., Thesis, Florida International University.

Viehman TS, Mills DK, Meichel GW, Richardson LL. (2006). Culture and identification of Desulfovibrio spp. from corals infected by black band disease on Dominican and Florida Keys reefs. Dis Aquat Organ 69:119-127.

Viehman TS, Richardson LL. (2000). Motility patterns of Beggiatoa and Phormidium corallyticum in black band disease. Proc 9th Int Coral Reef Sym 2:1251-1255.

Voelkert E, Grant DR. (1970). Determination of homoserine as the lactone. Anal Biochem 34:131137. 
Voss JD, Richardson LL. (2006). Coral diseases near Lee Stocking Island, Bahamas: patterns and potential drivers. Dis Aquat Organ 69:33-40.

Waters CM, Bassler BL. (2005). Quorum sensing: cell-to-cell communication in bacteria. Annu Rev Cell Dev Biol 21:319-346.

Waters CM, Lu W, Rabinowitz JD, Bassler BL. (2008). Quorum sensing controls biofilm formation in Vibrio cholerae through modulation of cyclic di-GMP levels and repression of vpsT. J Bacteriol 190:2527-2536.

Weil E. (2004). Coral Reef Diseases in the Wider Caribbean. In: Rosenberg E, Loya Y (eds). Coral Reef Health and Disease. Springer- Verlag: Berlin, pp 35-68.

Weil E, Smith GW, Gil-Agudelo DL. (2006). Status and progress in coral reef disease research. Dis Aquat Organ 69:1-7.

Welch M, Todd DE, Whitehead NA, McGowan SJ, Bycroft BW, Salmond GP. (2000). N-acyl homoserine lactone binding to the CarR receptor determines quorum-sensing specificity in Erwinia. Embo J 19:631-641.

Wiener P. (1996). Experimental studies on the ecological role of antibiotic production in bacteria. Evol Ecol 10:405-421.

Wild C, Woyt H, Whettel M. (2005). Influence of coral mucus on nutrient fluxes in carbonate sands. Mar Ecol Prog Ser 287:87-98.

Wilkinson C. (2008). Status of Coral Reefs of the World: 2008. Global Coral Reef Monitoring Network and Reef and Rainforest Research Center, Townsville, Australia. 296pp.

Williams P. (2007). Quorum sensing, communication and cross-kingdom signalling in the bacterial world. Microbiology 153:3923-3938.

Wood DW, Gong F, Daykin MM, Williams P, Pierson III LS. (1997). N-acyl-homoserine lactonemediated regulation of phenazine gene expression by Pseudomonas aureofaciens 30-84 in the wheat rhizosphere. J Bacteriol 179:7663-7670.

Wu L, Estrada O, Zaborina O, Bains M, Shen L, Kohler JE, Patel N, Musch MW, Chang EB, Fu YX, Jacobs MA, Nishimura MI, Hancock RE, Turner JR, Alverdy JC. (2005). Recognition of host immune activation by Pseudomonas aeruginosa. Science 309:774-777.

Xavier KB, Bassler BL. (2003). LuxS quorum sensing: more than just a numbers game. Curr Opin Microbiol 6:191-197.

Xavier KB, Bassler BL. (2005). Regulation of uptake and processing of the quorum-sensing autoinducer Al-2 in Escherichia coli. J Bacteriol 187:238-248.

Yates EA, Philipp B, Buckley C, Atkinson S, Chhabra SR, Sockett RE, Goldner M, Dessaux Y, Cámara M, Smith, H, Williams P. (2002). N-acylhomoserine lactones undergo lactonolysis in a $\mathrm{pH}-$, temperature-, and acyl chain length-dependent manner during growth of Yersinia pseudotuberculosis and Pseudomonas aeruginosa. Infect Immun 70:5635-5646.

Yoon JH, Lee SY, Kang SJ, Lee CH, Oh TK. (2007). Pseudoruegeria aquimaris gen. nov., sp. nov., isolated from seawater of the East Sea in Korea. Int J Syst Evol Microbiol 57:542-547. 
APPENDIX 
Mean growth rate constants $\left(\mu=h^{-1}\right.$, top number) and generation times ( $g=$ doublings/hour, bottom number) for the 19 isolates examined in the growth challenge assay. Pink cells indicate culture filtrates (CFs) that significantly ( $p<$

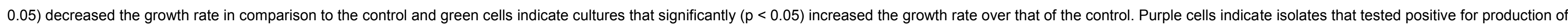
acyl homoserine lactones (AHLs) and yellow cells indicate isolates that tested negative in the quorum sensing assays.

\begin{tabular}{|c|c|c|c|c|c|c|c|c|c|c|c|c|c|c|c|c|c|c|c|c|c|c|}
\hline \multirow[b]{2}{*}{$\begin{array}{l}\text { Isolate } \\
\text { Culture }\end{array}$} & \multirow[b]{2}{*}{ Control } & \multicolumn{19}{|c|}{ Culture Filtrates } & \multirow{2}{*}{$\begin{array}{c}\text { No.CFs } \\
\text { Inhibiting } \\
\text { Isolate } \\
\text { Culture }\end{array}$} & \multirow{2}{*}{$\begin{array}{c}\text { No.CFs } \\
\text { Stimulating } \\
\text { Isolate } \\
\text { Culture }\end{array}$} \\
\hline & & BBD-FTL-6j & $\begin{array}{c}\text { BBD-FTL- } \\
8 \mathrm{C}\end{array}$ & \begin{tabular}{|} 
BBD-FLK- \\
1d
\end{tabular} & $\begin{array}{c}\text { BSML-FTL- } \\
6 \mathrm{w}\end{array}$ & $\begin{array}{c}\text { BSML-FTL- } \\
71\end{array}$ & $\begin{array}{c}\text { HSML-FTL- } \\
9 \mathrm{c}\end{array}$ & $\begin{array}{c}\text { HSML-FTL- } \\
9 \mathrm{e}\end{array}$ & $\begin{array}{c}\text { HSML-FTL- } \\
9 i\end{array}$ & $\begin{array}{c}\text { HSMLLFTL- } \\
10 \mathrm{a}\end{array}$ & \begin{tabular}{|c|} 
BBD-FTL- \\
$1 \mathrm{~h}$
\end{tabular} & $\begin{array}{c}\text { BBD-FTL- } \\
6 \mathrm{~d}\end{array}$ & \begin{tabular}{|c|} 
BBD-FTL- \\
$6 n$
\end{tabular} & $\begin{array}{c}\text { BBD-FTL- } \\
6 \mathrm{p}\end{array}$ & \begin{tabular}{|c} 
BBD-FLK- \\
$1 \mathrm{e}$
\end{tabular} & $\begin{array}{c}\text { BSML-FTL- } \\
6 \mathrm{u}\end{array}$ & $\begin{array}{c}\text { BSML-FTL- } \\
7 \mathrm{~d}\end{array}$ & $\begin{array}{c}\text { BSML-FTL- } \\
7 q\end{array}$ & $\mid \begin{array}{c}\text { BSML-FLK- } \\
1 d\end{array}$ & $\begin{array}{c}\text { HSML-FTL- } \\
10 \mathrm{r}\end{array}$ & & \\
\hline \multirow[t]{2}{*}{ BBD-FTL-6j } & 0.171 & & 0.168 & 0.161 & 0.168 & 0.172 & 0.358 & 0.146 & 0.148 & 0.166 & 0.178 & 0.173 & 0.156 & 0.160 & 0.172 & 0.170 & 0.163 & 0.173 & 0.161 & 0.154 & & Cunture \\
\hline & & 0.002 & 0.242 & $\begin{array}{l}.232 \\
0.002\end{array}$ & 0.243 & $\begin{array}{l}0.247 \\
0.002\end{array}$ & $\begin{array}{l}0.016 \\
0.002\end{array}$ & 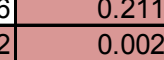 & $\begin{array}{l}0.214 \\
0.002\end{array}$ & $\begin{array}{l}0.240 \\
0.002\end{array}$ & $\begin{array}{l}0.256 \\
0.002\end{array}$ & $\mid 0.249$ & $\begin{array}{l}0.224 \\
0.002\end{array}$ & 0.230 & $\frac{0.248}{0.002}$ & $\begin{array}{l}0.245 \\
0.002\end{array}$ & $\frac{0.236}{0.002}$ & $\begin{array}{l}0.250 \\
0.002\end{array}$ & $\begin{array}{l}0.233 \\
0.002 \\
\end{array}$ & 0.222 & 5 & 0 \\
\hline BBD-FTL-8C & 0.565 & $\begin{array}{l}0.472 \\
\end{array}$ & & 0.48 & 0.471 & 0.481 & 0.494 & 0.510 & 0.488 & 0.422 & 0.494 & $\begin{array}{l}0.484 \\
\end{array}$ & 0.423 & 0.514 & 0.509 & $\begin{array}{l}0.539 \\
\end{array}$ & 0.548 & 0.505 & 0.513 & 0.221 & 16 & 0 \\
\hline BBD-FLK-1d & $\begin{array}{l}0.222 \\
0.320\end{array}$ & $\begin{array}{l}0.183 \\
0.263\end{array}$ & $\begin{array}{l}0.203 \\
0.293\end{array}$ & & $\begin{array}{l}0.202 \\
0.291\end{array}$ & $\begin{array}{l}0.190 \\
0.274\end{array}$ & $\begin{array}{l}0.193 \\
0.278\end{array}$ & $\begin{array}{l}0.198 \\
0.286\end{array}$ & \begin{tabular}{l|}
0.190 \\
0.275
\end{tabular} & $\begin{array}{l}0.058 \\
0.084\end{array}$ & $\begin{array}{l}0.226 \\
0.326\end{array}$ & $\begin{array}{l}0.236 \\
0.340\end{array}$ & \begin{tabular}{l|}
0.242 \\
0.349
\end{tabular} & $\begin{array}{l}0.238 \\
0.343\end{array}$ & $\begin{array}{l}0.205 \\
0.295\end{array}$ & $\begin{array}{l}0.209 \\
0.301\end{array}$ & $\begin{array}{l}0.197 \\
0.284\end{array}$ & $\begin{array}{l}0.209 \\
0.301\end{array}$ & $\begin{array}{l}0.215 \\
0.309\end{array}$ & $\begin{array}{l}0.189 \\
0.273\end{array}$ & 1 & 0 \\
\hline BSML-FTL-6w & $\begin{array}{l}0.137 \\
0.198\end{array}$ & $\begin{array}{l}0.137 \\
0.198\end{array}$ & $\begin{array}{l}0.090 \\
0.129 \\
\end{array}$ & $\begin{array}{l}0.101 \\
0.145\end{array}$ & & $\begin{array}{l}0.021 \\
0.030\end{array}$ & $\begin{array}{l}0.110 \\
0.195 \\
0.195\end{array}$ & $\begin{array}{l}0.108 \\
0.156\end{array}$ & $\begin{array}{l}0.124 \\
0.178\end{array}$ & $\begin{array}{l}0.021 \\
0.030\end{array}$ & $\begin{array}{l}0.107 \\
0.154\end{array}$ & \begin{tabular}{|l|}
0.033 \\
0.048
\end{tabular} & $\begin{array}{l}0.028 \\
0.040\end{array}$ & $\begin{array}{l}0.045 \\
0.219 \\
0.219\end{array}$ & $\begin{array}{l}0.132 \\
0.190\end{array}$ & $\begin{array}{l}0.146 \\
0.211\end{array}$ & $\begin{array}{l}0.045 \\
0.045 \\
0.065\end{array}$ & $\begin{array}{l}0.027 \\
0.040\end{array}$ & $\begin{array}{l}0.009 \\
0.072 \\
0.104\end{array}$ & $\begin{array}{l}0.175 \\
0.126 \\
0.182\end{array}$ & 1 & 0 \\
\hline BSML-FTL-7I & $\begin{array}{l}0.214 \\
0.0309\end{array}$ & $\begin{array}{l}0.212 \\
0.306\end{array}$ & $\begin{array}{l}0.206 \\
0.297\end{array}$ & $\begin{array}{l}0.200 \\
0.294\end{array}$ & $\begin{array}{l}0.215 \\
0.310\end{array}$ & & $\begin{array}{l}0.209 \\
0.0202\end{array}$ & $\begin{array}{l}0.202 \\
0.291\end{array}$ & $\begin{array}{l}0.206 \\
0.297\end{array}$ & $\begin{array}{l}0.013 \\
0.018\end{array}$ & $\begin{array}{l}0.197 \\
0.278\end{array}$ & \begin{tabular}{|l|}
0.203 \\
0.292
\end{tabular} & $\begin{array}{l}0.219 \\
0.316\end{array}$ & $\begin{array}{l}0.212 \\
0.212 \\
0.306\end{array}$ & $\begin{array}{l}0.208 \\
0.000\end{array}$ & $\begin{array}{l}0.183 \\
0.264\end{array}$ & $\begin{array}{l}0.203 \\
0.292\end{array}$ & $\begin{array}{l}0.0222 \\
0.320\end{array}$ & $\begin{array}{l}0.104 \\
0.2268 \\
0.298\end{array}$ & $\begin{array}{l}0.034 \\
0.049\end{array}$ & 3 & 0 \\
\hline HSML-FTL-9c & $\begin{array}{l}0.226 \\
0.326\end{array}$ & \begin{tabular}{l|}
0.237 \\
0.341
\end{tabular} & $\begin{array}{l}0.240 \\
0.346\end{array}$ & $\begin{array}{l}0.215 \\
0.310\end{array}$ & $\begin{array}{l}0.238 \\
0.343\end{array}$ & $\begin{array}{l}0.239 \\
0.345\end{array}$ & & $\begin{array}{l}0.244 \\
0.353\end{array}$ & \begin{tabular}{l|}
0.297 \\
0.428
\end{tabular} & $\begin{array}{l}0.046 \\
0.067\end{array}$ & $\begin{array}{l}0.202 \\
0.291\end{array}$ & $\begin{array}{l}\mid .224 \\
0.223 \\
0.323\end{array}$ & $\begin{array}{l}0.233 \\
0.36\end{array}$ & $\begin{array}{l}0.210 \\
0.2102\end{array}$ & $\begin{array}{l}0.190 \\
0.074\end{array}$ & $\begin{array}{l}0.2194 \\
0.280 \\
0.28\end{array}$ & $\begin{array}{l}0.232 \\
0.335\end{array}$ & $\begin{array}{l}0.0229 \\
0.330\end{array}$ & $\begin{array}{l}0.204 \\
0.294\end{array}$ & $\begin{array}{l}0.0203 \\
0.292\end{array}$ & 0 & 0 \\
\hline HSML-FTL-9e & $\begin{array}{l}0.120 \\
0.173\end{array}$ & $\begin{array}{l}145 \\
209\end{array}$ & $\begin{array}{l}0.139 \\
0.201\end{array}$ & $\begin{array}{l}0.101 \\
0.145\end{array}$ & $\begin{array}{l}0.0703 \\
0.148\end{array}$ & $\begin{array}{l}0.126 \\
0.182 \\
0.182\end{array}$ & $\begin{array}{l}0.128 \\
0.184\end{array}$ & & $\begin{array}{l}0.140 \\
0.202\end{array}$ & $\begin{array}{l}0.010 \\
0.014\end{array}$ & $\begin{array}{l}0.29 \\
0.136 \\
0.196\end{array}$ & \begin{tabular}{|l|}
0.116 \\
0.168
\end{tabular} & $\mid \begin{array}{l}\mid .30 .131 \\
0.190\end{array}$ & $\begin{array}{l}0.002 \\
0.134 \\
0.194\end{array}$ & $\begin{array}{l}0.214 \\
0.151 \\
0.218\end{array}$ & $\begin{array}{l}0.20153 \\
0.222\end{array}$ & $\begin{array}{l}0.135 \\
0.148 \\
0.213\end{array}$ & $\begin{array}{l}0.350 \\
0.251\end{array}$ & $\begin{array}{l}0.294 \\
0.095 \\
0.137\end{array}$ & $\begin{array}{l}0.292 \\
0.062 \\
0.089\end{array}$ & 2 & 1 \\
\hline HSML-FTL-9i & 0.061 & $\begin{array}{l}.2062 \\
0.062\end{array}$ & & & 0.140 & $\begin{array}{l}0.002 \\
0.007 \\
0.070\end{array}$ & 0.0104 & 0.051 & & $\begin{array}{l}0.014 \\
0.035\end{array}$ & $\begin{array}{l}.1903 \\
0.037\end{array}$ & $\begin{array}{l}0.100 \\
0.045 \\
\end{array}$ & $\begin{array}{l}0.1049 \\
0.049\end{array}$ & $\begin{array}{l}0.044 \\
0.045\end{array}$ & $\begin{array}{l}0.10 \\
0.033 \\
0.00\end{array}$ & $\begin{array}{l}0.220 \\
0.030\end{array}$ & $\begin{array}{l}0.2515 \\
0.049\end{array}$ & 0.051 & 0.059 & $\begin{array}{l}0.009 \\
0.010 \\
0.015\end{array}$ & 2 & \\
\hline \multirow[t]{2}{*}{ HSML-FTL-10a } & $\begin{array}{l}0.088 \\
0.163 \\
0.252\end{array}$ & & & & & & & $\begin{array}{l}0.074 \\
0.146 \\
0.10\end{array}$ & & 0.050 & $\begin{array}{l}0.053 \\
0.148 \\
0213\end{array}$ & & & & $\begin{array}{l}0.048 \\
0.142 \\
0.024\end{array}$ & \begin{tabular}{l|}
0.044 \\
0.140 \\
$0 ? 0$
\end{tabular} & $\begin{array}{l}0.070 \\
0.147 \\
012\end{array}$ & $\begin{array}{l}0.070 \\
0.147 \\
021 ?\end{array}$ & 0.084 & $\begin{array}{l}0.015 \\
0.150 \\
0,17\end{array}$ & 0 & 0 \\
\hline & & & & & & & & & & & 0.213 & & & & & & & & & 0.217 & 14 & 0 \\
\hline BBD-FTL-1h & $\begin{array}{l}0.095 \\
0.137\end{array}$ & $\begin{array}{l}0.106 \\
\end{array}$ & 0.097 & 0.101 & 0.104 & 0.022 & 0.090 & 0.102 & $\begin{array}{l}0.099 \\
0.143\end{array}$ & 0.080 & & $\begin{array}{l}0.094 \\
0.13\end{array}$ & 0.101 & 0.098 & 0.100 & $\begin{array}{l}0.103 \\
0148\end{array}$ & 0.106 & 0.099 & 0.098 & 0.102 & 2 & 4 \\
\hline \multirow{2}{*}{ BBD-FTL-6d } & & $\frac{0.1}{0.2}$ & $\begin{array}{l}0.140 \\
0.221\end{array}$ & & & 0.032 & $\frac{0.130}{0.214}$ & $\frac{0.141}{0.232}$ & $\begin{array}{l}0.145 \\
0.222\end{array}$ & $\begin{array}{l}0.115 \\
0.046\end{array}$ & 0.232 & & $\begin{array}{l}0.146 \\
0.224 \\
\end{array}$ & 0.142 & 0.2340 & $\begin{array}{l}0.148 \\
0.233 \\
\end{array}$ & $\frac{0.153}{0.211}$ & $\begin{array}{l}0.143 \\
0.223\end{array}$ & 0.142 & 0.141 & 2 & 4 \\
\hline & 0.328 & & & & & & & 0.334 & 0.320 & 0.066 & 0.335 & & 0.323 & 0.314 & 0.332 & 0.336 & 0.305 & 0.322 & 0.320 & 0.292 & 5 & 0 \\
\hline BBD-FTL-6n & 0. & & & & & 0.219 & 0.236 & 0.240 & 0.236 & 0.230 & & $\begin{array}{ll}0.246 \\
\end{array}$ & & $\begin{array}{l}0.244 \\
0353\end{array}$ & 0.245 & $\begin{array}{ll}0.239 \\
\end{array}$ & 0.242 & 0.226 & 0.230 & 0.237 & 2 & 3 \\
\hline \multirow{2}{*}{ BBD-FTL-6p } & 0.0335 & $\begin{array}{l}0.319 \\
0.305\end{array}$ & $\begin{array}{l}0.255 \\
0.314\end{array}$ & & 0.341 & 0.315 & $\frac{0.341}{0.290}$ & $\frac{0.346}{0.292}$ & $\begin{array}{l}0.340 \\
0.282\end{array}$ & $\frac{0.332}{0.285}$ & $\begin{array}{l}0.349 \\
0.278\end{array}$ & $\begin{array}{l}0.355 \\
0.281\end{array}$ & \begin{tabular}{|l|l|}
0.271 \\
\end{tabular} & 0.353 & $\frac{0.354}{0.276}$ & $\frac{0.345}{0.211}$ & 0.350 & $\begin{array}{l}0.326 \\
0.301\end{array}$ & $\begin{array}{l}0.332 \\
0.309\end{array}$ & 0.342 & 2 & 3 \\
\hline & 0.441 & 0.440 & 0.453 & & 0.419 & & & 0.422 & 0.407 & 0.411 & 0.401 & 0.405 & 0.391 & & 0.397 & 0.304 & 0.383 & 0.434 & 0.446 & 0.426 & 4 & 0 \\
\hline \multirow[t]{2}{*}{ BBD-FLK-1e } & 0.2 & $\begin{array}{ll}0.223 \\
\end{array}$ & & & & & & 0.223 & $\begin{array}{ll}0.226 \\
\end{array}$ & 0.130 & & 0.150 & $\begin{array}{ll}0.148 \\
\end{array}$ & 0.150 & & 0.160 & 0.190 & & & 0.163 & 7 & 0 \\
\hline & & & 0.258 & & & & & & & 0.187 & & & & 0.217 & & 0.230 & & & & & 7 & 0 \\
\hline BSML-FTL-6u & $\begin{array}{l}0.151 \\
0.218\end{array}$ & $\begin{array}{l}0.107 \\
0.155\end{array}$ & $\begin{array}{l}0.145 \\
0.209\end{array}$ & $\begin{array}{l}0.136 \\
0.201\end{array}$ & $\begin{array}{l}0.122 \\
0.177\end{array}$ & $\begin{array}{l}0.071 \\
0.02\end{array}$ & $\begin{array}{l}0.186 \\
0.268\end{array}$ & $\begin{array}{l}0.142 \\
0.205\end{array}$ & $\begin{array}{l}0.120 \\
0.173\end{array}$ & $\begin{array}{l}0.153 \\
0.220\end{array}$ & $\begin{array}{l}0.154 \\
0.223\end{array}$ & $\begin{array}{l}0.163 \\
0.235\end{array}$ & $\begin{array}{l}0.193 \\
0.278\end{array}$ & $\begin{array}{l}0.189 \\
0.273\end{array}$ & $\begin{array}{l}0.185 \\
0.267\end{array}$ & & $\begin{array}{l}0.140 \\
0.202\end{array}$ & $\begin{array}{l}0.135 \\
0.194\end{array}$ & $\begin{array}{l}0.118 \\
0.170\end{array}$ & $\begin{array}{l}0.162 \\
0.234\end{array}$ & 0 & 0 \\
\hline \multirow{2}{*}{ BSML-FTL-7d } & 0.179 & 0.130 & 0.141 & 0.163 & 0.152 & 0.007 & 0.16 & 0.167 & 0.11 & 0.055 & 0.148 & 0.16 & $\begin{array}{ll}0.167 \\
\end{array}$ & 0.1 & 0.179 & 0.18 & & 0.145 & 0.1 & 0.150 & & \\
\hline & & 0.187 & 0.204 & & & & & & & & & & & & & & & 0.210 & & & 9 & \\
\hline \multirow{2}{*}{ BSML-FTL-7q } & 0.092 & 0.036 & 0.020 & 0.01 & 0.01 & 0.017 & 0.06 & 0.044 & 0.0 & 0.043 & $0 . c^{-1}$ & 0.0 & & 0.6 & 0.0 & 0.0 & 0.0 & & 0.075 & 0.097 & & \\
\hline & & 0.053 & 0.029 & & & & & & 0.0 & 0.062 & & 0.0 & & 00 & & 0.0 & & & 0.108 & & & \\
\hline BSML-FLK-1d & $\begin{array}{l}0.078 \\
0.112\end{array}$ & $\begin{array}{l}0.089 \\
0.128\end{array}$ & $\begin{array}{l}0.073 \\
0.106\end{array}$ & $\begin{array}{l}0.081 \\
0.115\end{array}$ & $\begin{array}{l}0.079 \\
0.114\end{array}$ & $\begin{array}{l}0.060 \\
0.087\end{array}$ & $\begin{array}{l}0.078 \\
0.113\end{array}$ & $\begin{array}{l}0.083 \\
0.119\end{array}$ & $\begin{array}{l}0.081 \\
0.117\end{array}$ & $\begin{array}{l}0.068 \\
0.098\end{array}$ & $\begin{array}{l}0.0699 \\
0.099\end{array}$ & $\begin{array}{l}0.074 \\
0170\end{array}$ & $\begin{array}{l}0.094 \\
0136\end{array}$ & $\begin{array}{l}0.063 \\
0.01\end{array}$ & 0.064 & $\begin{array}{l}0.065 \\
0.094\end{array}$ & 0.091 & $\begin{array}{l}0.085 \\
0.123\end{array}$ & & $\begin{array}{l}0.066 \\
0.095\end{array}$ & & \\
\hline & & & & 0.1115 & 0.114 & & & $\frac{0.119}{0.139}$ & & & & & $\begin{array}{l}0.136 \\
0.125 \\
\end{array}$ & & 0.093 & & & & & & & 0 \\
\hline HSML-FTL-10r & 0.211 & 0.189 & 0.181 & 0.170 & 0.192 & 0.030 & $\begin{array}{l}.0120 \\
0.182\end{array}$ & 0.200 & 0.180 & 0.140 & 0.171 & $\begin{array}{l}0.192 \\
0.191\end{array}$ & $\begin{array}{l}.1200 \\
0.181\end{array}$ & 0.171 & 0.117 & 0.187 & 0.229 & $\begin{array}{l}0.131 \\
0.188\end{array}$ & 0.1 & & 1 & 0 \\
\hline & & & & & & & & & & & & & & & & & & & & & & \\
\hline o. Isolates St & & & & & & & & & & & & & & & & & & & & & & \\
\hline
\end{tabular}

